UNIVERSIDADE DE SÃO PAULO

FACULDADE DE FILOSOFIA, LETRAS E CIÊNCIAS HUMANAS

DEPARTAMENTO DE LETRAS MODERNAS

PROGRAMA DE PÓS-GRADUAÇÃO EM ESTUDOS LINGÜÍSTICOS E LITERÁRIOS EM INGLÊS

\title{
UTOPIAS PÓS-MODERNAS
}

Uma leitura da trilogia marciana de Kim Stanley Robinson

Rodrigo Marcelo Viña Bertolotto 
UNIVERSIDADE DE SÃO PAULO

FACULDADE DE FILOSOFIA, LETRAS E CIÊNCIAS HUMANAS

DEPARTAMENTO DE LETRAS MODERNAS

PROGRAMA DE PÓS-GRADUAÇÃO EM ESTUDOS LINGÜÍSTICOS E

LITERÁRIOS EM INGLÊS

\section{UTOPIAS PÓS-MODERNAS}

Uma leitura da trilogia marciana de Kim Stanley Robinson

Rodrigo Marcelo Viña Bertolotto

Dissertação apresentada para o processo ao Programa de Pós-Graduação em Estudos Lingüísticos e Literários em Inglês, do Departamento de Letras Modernas da Faculdade de Filosofia, Letras e Ciências Humanas da Universidade de São Paulo para a obtenção do título de Mestre em Letras

Orientadora: Prof. Dra. Maria Elisa Burgos Pereira da Silva Cevasco

São Paulo

2009 


\section{AGRADECIMENTOS}

A Maria Elisa, por esses anos como professora e orientadora.

Aos colegas do Grupo de Estudos da Cultura, pelo incentivo, em especial, o Elton, por me emprestar a enciclopédia de ficção científica.

A minha irmã, Carolina, por ler, reler e corrigir este texto, tendo como dupla função embalar a pequena Gabriela.

A meu pai, Carlos, por me impulsionar a ler literatura espacial, predileção de toda sua vida.

A Alexandra e ao Alan, por me ajudarem a garimparem exemplares e artigos em viagens pelo mundo e voltas pelo cyberspace.

Ao Márcio e a Raphaela por suas leituras e dicas. 


\section{SUMÁRIO}

I - Utopias inimagináveis: Apresentação..........................................................07

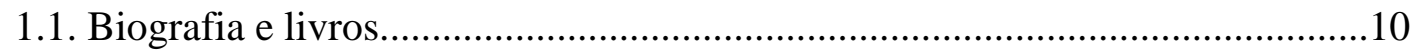

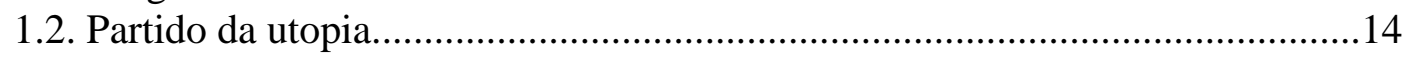

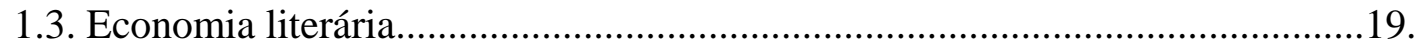

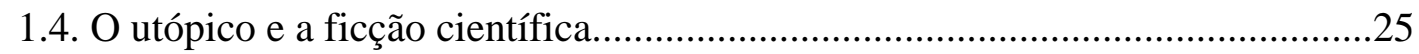

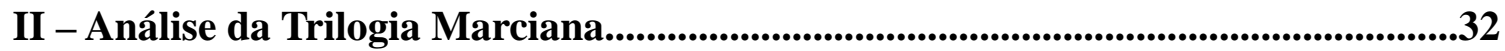

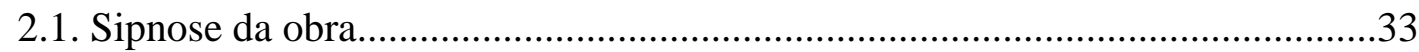

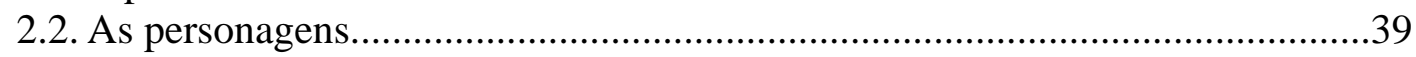

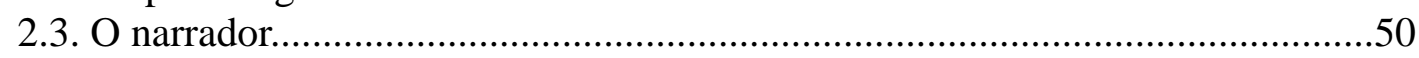

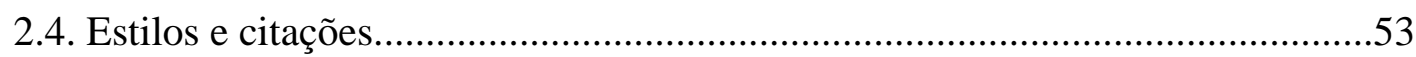

2.5. O cientista como herói revolucionário.............................................................57

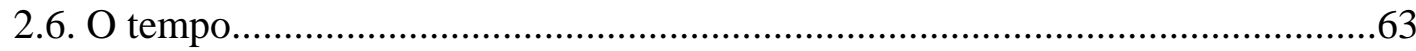

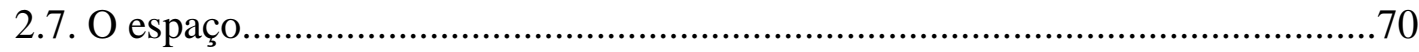

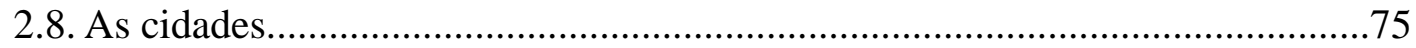

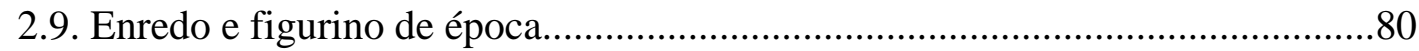

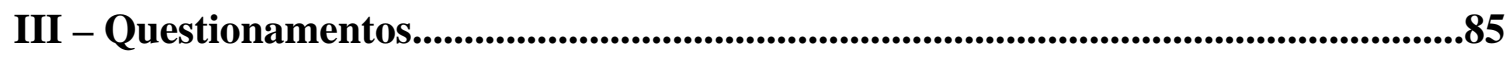

3.1. Solução pós-moderna para se chegar à sociedade ideal......................................87

3.2. Marte como espelho dos EUA........................................................................94

IV - Referências Bibliográficas.................................................................................104

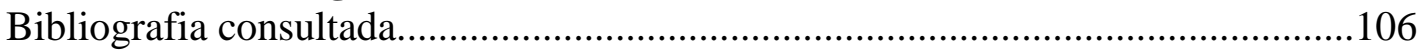




\title{
RESUMO
}

O objeto de estudo deste trabalho é a trilogia marciana de Kim Stanley Robinson, com a publicação de Red Mars, em 1993; Green Mars, em 1994; e Blue Mars, em 1996. A partir do questionamento de sua visão de utopia, que é corroborada pelo crítico materialista Fredric Jameson em seu livro Archaeologies of the Future, de 2005, procuro analisar a solução pós-moderna e multicultural para uma sociedade ideal, apresentada por ambos. Assim, essa dissertação discute o alcance dessa utopia fragmentada e aponta como ela é resultado da perspectiva histórica e de um ponto de vista. Outro objetivo é demonstrar como os Estados Unidos moldam o imaginário da trilogia, repetindo uma tradição da ficção científica do país.

Palavras-chave: Kim Stanley Robinson. ficção científica. Utopia. Fredric Jameson. pósmodernismo.

\begin{abstract}
The aim of this paper is to present a reading of Mars Trilogy, by Kim Stanley Robinson, published in 1993 (Reds Mars), 1994 (Green Mars), and 1996 (Blue Mars). By questioning his idea of utopia, reinforced by the materialist critic Fredric Jameson in Archaeologies of the Future (2005), I investigate the postmodern and multicultural solution for an ideal society they both propose. Therefore, one of the main purposes of this dissertation is to discuss this fragmented utopia and how its result reveals the historical perspective and the point of view. Another drive is to demonstrate that the United States construct the imagery behind the trilogy, repeating a tradition in the local science fiction.
\end{abstract}

Key words: Kim Stanley Robinson. Science fiction. Utopia. Fredric Jameson. Postmodernity. 


\title{
I. UTOPIAS INIMAGINÁVEIS: APRESENTAÇÃO
}

\author{
“Todas as utopias sociais, \\ desde a de Platão, fundem-se \\ numa desalentadora semelhança com \\ aquilo contra o qual foram concebidas." \\ Theodor W. Adorno ("Mensagens numa Garrafa”)
}

Professor e aluno, os norte-americanos Fredric Jameson e Kim Stanley Robinson se encarregam, cada um à sua maneira (o primeiro de forma ensaística, e o segundo em obras de ficção científica), de imaginar a idéia de utopia nesta época formada e conformada pelo capitalismo tardio e a pós-modernidade.

Em um tempo que é mais fácil vislumbrar o apocalipse que uma mudança no modo de produção, os dois ousaram propor formas de chegar a uma sociedade ideal, tomando a mentalidade que molda nossos dias e tentando fazer as conexões que sua dinâmica desconexa, em geral, interdita. Em sintonia de idéias, ambos autores arriscam se apropriar da lógica pós-moderna para escapar da realidade atual que a gera. Todavia, como todo projeto utópico, seja ele literário ou teórico, o momento histórico se revela o motor, mas também o limitador. Ao fim, Robinson acaba por promover uma utopia que parece um simulacro da realidade norte-americana atual, porém, reformado ao gosto dos setores progressistas daquele país.

Ao longo desta dissertação, serão analisadas as idéias presentes na trilogia marciana de Robinson, seu diálogo com o volume teórico Archaeologies of the Future (Arqueologia do Futuro) de Jameson (2005), confrontadas com as de outros autores do pensamento utópico, da crítica cultural, bem como, do universo específico da ficção científica. O objetivo dessa dissertação é mostrar como o ponto de vista acaba por ser preponderante nas formulações utópicas deles.

A colaboração e a proximidade entre os dois são explícitas. O teórico cita mais de duas dezenas de vezes Robinson em Archaeologies of the Future, fora dedicar o capítulo final para analisar a trilogia marciana do ex-pupilo, o que deixa a impressão de que toda a trajetória do gênero ficção científica conflui para esse autor. Além disso, na dedicatória do livro inclui "Kim” na lista dos “meus camaradas no Partido da Utopia”.

Por sua vez, o escritor coloca o nome de seu ex-professor na Universidade da Califórnia estampado na página de agradecimentos, homenageando quem colaborou na construção do épico sobre a colonização de Marte, a trilogia formada por Red Mars - Marte Vermelho (1993), Green Mars - Marte Verde (1994) e Blue Mars - Marte Azul (1996).

Prova desse diálogo é que em um dos textos presente no volume sobre ficção científica, "The Future As Disruption” (O Futuro Como Ruptura), o ensaísta apresenta uma proposta de utopia, baseada em um federalismo (ele assume que o termo anda "desgastado", mas que vale "até que tenhamos um melhor”), de uma semelhança “inescapável”, ele confessa, com o desfecho da ficção de Robinson.

Jameson sugere duas medidas anticapitalistas, que, para ele, são fundamentais no caminho a um novo sistema utópico mundial: o direito de migrar e a abolição das taxas. "O primeiro torna impossível o crescimento e a expansão necessários para o capital, o segundo retira o meio pelo qual 
o capital se acumula", sentencia o acadêmico que virou uma referência nos últimos anos nos estudos da cultura.

Como Jameson observa, o dinheiro circula na economia atual quase sem barreiras pelo mundo, enquanto muros, cercas elétricas, burocracias e radares garantem que a maioria dos estratos sociais não se mexa de seus lugares de origem - esse é um dos truques para a riqueza se juntar em poucas mãos. ${ }^{1}$

Pois as andanças dos personagens de utopia em utopia são uma das tônicas da sociedade marciana imaginada por Robinson. Além disso, o direito de migração de terráqueos para Marte é o detonador da revolução de veludo que encerra a trilogia.

A mesma coisa, contudo, não se pode falar sobre o fim dos impostos projetado por Jameson: a constituição marciana (discutida e votada nas cerca de 50 páginas do capítulo três do terceiro volume) prevê impostos para empresas, mesmo ficando todas elas arrendadas por seus trabalhadores. Dessas duas constatações, pode-se depreender que Jameson e Robinson não concordam em tudo, como outros exemplos nesse trabalho vão mostrar.

Essas abolições, que podem ser implantadas com canetadas ou decretos, são comuns nas obras utópicas - elas acabaram diversas vezes com a figura do dinheiro, o que é pregado desde o monástico More. Todavia, assim como Robinson, Jameson descarta essa medida, acreditando que isso traria mais problemas que soluções atualmente.

A discussão em torno da utopia vive na atualidade um de seus momentos de baixa, como outras vezes aconteceu ao longo dos cinco séculos desde o surgimento de Utopia de More. Por isso mesmo, Jameson abre um flanco no meio dos pensadores de esquerda, entre os pragmáticos que querem humanizar o capitalismo e os abstratos que buscam qualquer forma de resistência, para mostrar como é impreterível que se projete uma utopia, como forma de reforçar a idéia de ruptura, para que ela não saia do campo de visão da intelectualidade.

Em tempos pós-modernos, quando a visão das conexões e da totalidade é tarefa difícil, essa descrença utópica se deve principalmente ao sistema vigente, que parece funcionar por si só, como uma máquina bem azeitada que o capitalismo tardio imagina ter implantado mundialmente. Essa lógica faz, segundo as próprias palavras de Jameson, que uma mudança não só seja vista como inviável, mas também como inimaginável.

Até por isso a trilogia apresenta o frescor da novidade quando relata um dos passos certos da humanidade (a colonização de Marte está nos programas espaciais de vários países; e pesquisas, há tempos, tentam criar condições de vida humana levando em conta os extremos climáticos e a atmosfera diminuta do planeta), mas com uma guinada impensada para o pensamento hegemônico: uma revolução em direção a uma sociedade mais igualitária.

O relato do futuro próximo conta a colonização, a revolução política de Marte e a terraformação de Marte (denominação dada ao processo, até agora teórico, de modificar um planeta

\footnotetext{
${ }^{1}$ O intelectual esloveno, Slavoj Zizek, também lembra essa “velha oposição humanista marxista” da relação entre coisas e pessoas para criticar a celebração capitalista da "livre circulação” de mercadorias e o controle da migração. “O que se esconde atrás dessas medidas de proteção é a mera consciência de que o modelo atual de prosperidade capitalista recente não pode ser universalizado”, escreve à página 172 de seu livro Bem-vindos ao Deserto do Real! (2003).
} 
ou outro corpo celeste para que este tenha melhores condições de ser habitado por humanos ou outros animais). A ação parte do ano de 2026, com a viagem dos "Primeiros Cem", grupo de cientistas escolhidos pelos EUA e Rússia para serem os pioneiros da colonização do astro vizinho. O fechamento do enredo acontece na data de 2212, quando o conhecido planeta vermelho tem floresta, animais e oceanos, além de atmosfera respirável onde as utopias humanas podem se multiplicar e perseverar.

O primeiro volume, Red Mars, relata o começo da ocupação, mostrando os atritos dos representantes dos governos e das corporações terráqueas com os partidários de uma sociedade mais igualitária e preservacionista no planeta vermelho. Essa parte termina com a revolução frustrada de 2061, três dos principais protagonistas mortos (o revolucionário Arkadi Bogdanov, o carismático John Boone e o maquiavélico Frank Chalmers), as empresas metanacionais tomando as rédeas e a resistência marciana acuada em refúgios subterrâneos.

Já Green Mars, o livro intermediário, revela um cenário já modificado pela ocupação humana, que conta com sua primeira geração nascida por lá e com características adaptadas à gravidade e atmosfera marcianas. Com a articulação entre os pioneiros sobreviventes, os jovens nativos, a corporação “alternativa” Práxis e os diversos grupos colonizadores, nova revolta é coordenada e, dessa vez, bem sucedida, tendo à frente figuras como os pioneiros Nadia Cherneshevsky, Maya Toitovna, Coyote, o novato marciano Nirgal e o corporativo Arthur Randolph.

Blue Mars, publicação que encerra a série, descreve a rivalidade entre os distintos grupos da resistência, que agora no poder, atritam suas ideologias. A redação de uma Constituição organiza a política do planeta, cria diversas sociedades e leva ao papel de presidente global a Nadia. No desfecho da trilogia, surge uma tentativa de ocupação por parte das metanacionais terráqueas, que é rechaçada pela população marciana, que vai às ruas, faz uma espécie de revolução de veludo e festeja o sucesso de sua ação coletiva. 


\subsection{Biografias e livros}

A trilogia marciana consolidou a carreira como escritor de ficção deste ex-doutorando de Jameson e rendeu fama dentro da comunidade da science fiction mundial, com direito a vencer os prêmios Nebula e Hugo, equivalentes a Pulitzers do gênero e ganhar traduções para o francês, o espanhol, o alemão e o japonês - mas não para o português, por isso mesmo, os trechos citados nesta dissertação são traduções próprias a partir dos originais em inglês.

Sua produção, com uma freqüência entre anual e bienal de colocar novidades nas prateleiras, é esperada por um público cativo - aguarda-se para 2009, por exemplo, a publicação de Galileo’s Dream, livro inspirado na vida e idéias do físico italiano Galileu Galilei.

Kim Stanley Robinson nasceu em 23 de março de 1952 em Waukegan - Illinois, mas mudouse ainda pequeno com a família para o sul da Califórnia, onde cresceu. Na adolescência, descobriu ali seu interesse por ficção científica. "Eu cresci em uma comunidade rural lendo Mark Twain, então vi os bosques serem arrancados e substituídos por um pesadelo de condomínios e autoestradas. Pouco depois eu descobri a ficção científica da New Wave e reconheci ali a verdade sobre meu mundo", contou em entrevista para a revista eletrônica inglesa Infinity Plus (GEVERS, 1999), listando seus autores preferidos dessa linha (Ursula Le Guin, Gene Wolfe, Samuel Delany, Joanna Russ, Stanislaw Lem e os irmãos Boris e Nikolai Strugatski).

Logo depois do fascínio com o gênero, ele foi estudar literatura no campus de San Diego da Universidade da Califórnia, local considerado o berço dos estudos pós-modernos nos EUA, tendo como um dos mestres justamente Jameson. Na seqüência, fez seu mestrado em Inglês na Boston University.

No mesmo ano em que apresentou, orientado por Jameson, sua tese de doutorado sobre um dos mestres da ficção científica, Philip K. Dick, ele publicou seu primeiro romance, The Memory of Whiteness. Era 1976.

Robinson escreveu vários contos, novelas e um romance curto (Icehenge, a história de um grupo de arqueólogos no futuro longínquo que descobre vestígios de uma revolução marciana) até que se arriscou em sua primeira trilogia, começando com o volume intitulado The Wild Shore (1984). Os livros The Gold Coast (1988) e Pacific Edge (1990) completam a chamada trilogia de Orange County, região ao sul de Los Angeles onde Robinson viveu a maior parte de sua vida.

Essa série literária imaginou três futuros possíveis para um dos principais centros do capitalismo (só para se ter uma idéia: fica por lá a Disneyland). Em The Wild Shore, o cenário de 2047 é apocalíptico - ou como, os norte-americanos classificam, é o subgênero the-day-aftertomorrow. Na trama, após a guerra nuclear, os soviéticos dominam o mundo e concedem aos japoneses a Costa Oeste dos EUA, cujos sobreviventes vivem da agricultura e da pesca. Já The Gold Coast é uma distopia ambientada em 2027 que leva o american way of life ao seu limite de consumo, destruição e violência (a distopia é um futuro negativo, mas que serve de alerta, do tipo "vejam onde vamos parar se tudo continuar dessa maneira”). Essa trilogia termina com o volume utópico e ecológico Pacific Edge, em uma Califórnia de 2065 com os verdes dominando a política.

O trio de livros é um formato recorrente para que Robinson encaixe sua temática de fundo e seu estilo prolixo. Após a série marciana, ele prometeu abandonar esse tamanho, mas não cumpriu. E não foi diferente em sua mais recente produção no mercado: dessa vez é a série Science In the 
Capital, sobre o relacionamento entre ciência, dinheiro e poder em Washington. Os livros são Forty Signs of Rain (2004), Fifty Degrees Below (2005) e Sixty Days and Counting (2007), em um enredo que mistura pesquisadores e políticos em um distrito federal norte-americano inundado pelo aquecimento global - e novamente Robinson reserva para alguns cientistas o papel de "mocinhos".

Forty Signs of Rain foi lançado em junho de 2004. E dois desastres acabaram por colocar a obra de Robinson em evidência, mostrando que o cenário pintado por ele não era fruto de uma imaginação mirabolante: o tsunami no Oceano Índico em dezembro daquele ano e o furacão Katrina que arrasou Nova Orleans em agosto de 2005.

Nessa trilogia, o autor trata da terraformação no próprio planeta Terra, em uma ação para remediar estragos criados pelo derretimento polar. $\mathrm{O}$ tema fica ainda mais delicado, já que envolve um planeta habitado por milhares de espécies, em que cada medida (como lançar toneladas de sal no Oceano Atlântico ou bombardear nuvens com areia) pode ter conseqüências imprevisíveis. Os críticos apontaram que seu presidente fictício dos EUA, Phil Chase, se parece muito com o democrata Al Gore, derrotado por George W. Bush nas eleições de 2000 e que ganhou o Nobel da Paz de 2007 por seu trabalho conjunto com a ONU de alertar sobre os riscos do aquecimento global, além do Oscar pelo documentário An Inconvenient Truth (“Uma Verdade Inconveniente”) sobre o mesmo tema. Já o antecessor republicano de Chase é inspirado em Bush e declara "estado de guerra com a natureza” após a enchente na capital dos EUA.

Antes dessa trilogia, Robinson experimentou outro subgênero da ficção científica diferente do near future (futuro próximo). Ele publicou em 2002 o livro Years of Rice and Salt, cujo título inicial era A World Without Europe, uma "história alternativa" na qual ele projeta como seria o mundo se a peste bubônica tivesse devastado a civilização européia antes de ela se expandir pelo mundo, que, nessa ficção, é dominado no século 20 pelo Islã, Índia e China. Em qualquer subgênero em que Robinson se aventurou, percebe-se em toda sua produção um esforço em pensar o presente e imaginar de que forma ele poderia ser diferente daquele que nos coube viver.

Além do romance Antarctica que publicou em 1997 (escrito após viagem ao Pólo Sul), a produção logo posterior à trilogia marciana reserva um livro que serve para iluminar detalhes da obra analisada nesta dissertação. Robinson editou em 1999 o compêndio The Martians (Os Marcianos) (2003), que reúne enredos, idéias e cenários que não encaixaram na volumosa trilogia de quase 2.000 páginas.

Há nele contos com personagens de sua saga marciana e outros não citados anteriormente, além de uma série de poemas escritos por um fictício marciano no final do volume. Também está lá a novela Green Mars, escrita nos anos 80, segundo o próprio autor, só para poder deter os direitos do título para a posterior utilização, afinal, demoraria ainda a pesquisar e a escrever sua saga marciana, que ele inicialmente tinha planejado para ter umas 200 páginas, mas que, ao final, ficou cerca de dez vezes maior.

Uma das intrigas que ficaram de fora da trilogia foi a que relata mais detalhadamente o processo de seleção na Antártica dos "Primeiros Cem", tudo visto pelo ponto de vista do psiquiatra francês Michel Duval. No texto, ele se mostra embasbacado com a beleza das mulheres selecionadas, resiste à tentação da carne, acredita inicialmente nos métodos de seleção, mas logo vê que as pessoas fingem e atuam diante dele e que, nos bastidores, já formam camarilhas. Robinson imagina um desfecho diferente ao dado em sua trilogia, que a impossibilitaria: no final do conto "Michel in Antarctica" (Michel na Antártica), o psiquiatra aconselha os governos dos EUA e da Rússia e suas pastas aeroespaciais a abortarem o projeto com uma centena de cientistas em uma 
base permanente em Marte.

Na trilogia, a fase polar do livro tem apenas três páginas e são apenas descritas as personalidades dos selecionados, que só vão se revelando ao longo da viagem e nos primeiros anos no planeta vermelho. Michel também vê problemas no grupo, mas bem menos. E a solução por ele encontrada é que um psiquiatra seja enviado junto com os pioneiros (no caso, ele próprio).

Esse contraste entre os relatos sugere de forma bem clara a impressão que a própria trilogia já indica: Michel é uma figuração do próprio escritor em seu trabalho de montagem da linha do livro, escolhendo o grupo de personagens e seus destinos. Como será explicado mais adiante, outro indício disso é a montagem dos retângulos semânticos de Greimas no capítulo "Homesick”, em que o francês mostra a disposição por temperamentos de seus convivas fictícios, esquematizando pelo humor ou caráter futuras amizades e os futuros amores e ódios. Além disso, a personagem cumpre a função de "consciência" dos outros personagens: com seus questionamentos e explicações, bem ao estilo psicanalítico, ele ajuda em diálogos que Maya, Sax e Ann exponham seu mundo interior.

Michel e Maya também estão no centro de outro relato do compêndio: em "Michel in Provence" (Michel na Provença), o psiquiatra acaba não embarcando com os "Primeiros Cem”, visita Marte mais tarde, mas não se acostuma e acaba reencontrando Maya em um congresso sobre colonização espacial em Nice, surgindo também um romance, agora momentâneo e terrestre.

Outra narrativa “desencaixada” é o caso amoroso entre Maya e Desmond Hawkins, o Coyote. $\mathrm{Na}$ trilogia, a líder russa é a primeira a detectar a presença do intruso já durante a viagem interplanetária, mas a ligação dos dois durante as centenas de páginas é ocasional e não chega a se definir como uma amizade. Já no conto de The Martians, Maya vai atrás do homem desconhecido que vislumbrou na granja da nave e o encontra. Após a tradicional cena de sexo, eles se tornam amantes e confidentes. E as informações de Desmond com a manipulação de Maya cumprem uma função que poderia mudar os rumos do épico marciano. Com essas "experimentações" em torno da personagem russa, percebe-se claramente que sua função principal na trilogia é servir de elo passional ao enredo.

Na trilogia, o sexo repentino e a relação amorosa acontecem com os líderes John Boone e Frank Chalmers e cria um triângulo amoroso que resultará em um dos componentes da rivalidade desses dois protagonistas por Marte e por Maya.

É sintomático que no começo da trilogia se prefigure um grupo em que o sexo é mais ou menos livre (alguns casais, alguns celibatários, mas a troca de parceiros é generalizada). Esse arranjo, entretanto, não ajuda no desenrolar de uma trama dependente dos tradicionais ingredientes de ciúmes, inveja e desejo. Logo começam a se formar casais mais estáveis ou triângulos amorosos para o enredo se desenrolar com o típico tempero da tensão sexual. "Uma sociedade sem conflito raramente produz histórias excitantes”, crava o próprio Jameson (2005, p.82). E o sexo contribui com os temas políticos, econômicos e sociais na geração dos imbróglios na trilogia marciana.

Voltando a The Martians, Coyote fala em primeira pessoa no texto "Coyote Remembers" (Coyote Lembra) e mostra um lado sentimental, ausente na trilogia. O tom confessional aborda a parceira Maya, o filho Nirgal e a ex-namorada Hiroko, que ele amaldiçoa por não aparecer.

Por seu lado, o Coyote cumpre um papel coadjuvante na trilogia e, como outras personagenschave como Hiroko, Jackie e os árabes, não ganha o direito de ter um capítulo com o narrador focando suas ações e pensamentos. Por isso, ele vai e vem na trilogia, perdido seu rastro entre suas 
andanças por Marte. Já os árabes só aparecem na história quando são visitados pelas personagens focadas.

Em The Martians, contudo, Jackie ganha relato com estatura de protagonista: é o texto em primeira pessoa intitulado “Jackie On Zo" (Jackie sobre Zo). Ele dá uma dimensão mais "humana” à personagem que é descrita na trilogia como uma vampira sexual e política (quando o foco narrativo está em Maya) ou uma garota volúvel e ambiciosa (quando ouvimos a consciência de Nirgal). Nesse texto "expurgado" da trilogia, Jackie ganha voz, falando com carinho de Maya, com quem rivaliza durante a série sem poder dar a sua versão dos fatos. Jackie também relata a infância e adolescência de Zo, sua filha. Ao contrário da mãe, Zo tem direito ao narrador em sua escolta na trilogia, mas a jovem hedonista surge e morre na narrativa em dois capítulos, com uma vida perigosa e prazerosa. O aspecto revelador de "Jackie on Zo" é que esse texto caberia como uma luva na narrativa da trilogia, afinal, suas informações não chocam com o desenrolar da trama da obra maior. O procedimento mostra a mão do escritor para não conceder espaço para essas duas personagens.

A mesma sensação de corte se repete nos relatos "Keeping The Flame” (Mantendo a Chama) e "Sax Moments" (Momentos de Sax). O primeiro se desenrola quando Nirgal busca sua mãe e tropeça com dois velhos que se revelam Edvard Perrin e George Berkovic, que faziam parte dos “Primeiros Cem”, mais especificamente do grupo da “corporativa” Phyllis Boyle. Eles contam que ergueram um monumento para ela, defendem sua imagem e afirmam que as revoluções só trouxeram morte e destruição para Marte. Phyllis é outra vilã da trilogia e, portanto, não ganha maior consideração.

Já “Sax Moments” é uma coleção de relatos do cientista desde sua fase sob a identidade falsa de Stephen Lihdholm até o romance com Ann no final da trilogia. Seus trechos com saltos no tempo sugerem que foram limados da trilogia, afinal, são perfeitamente complementares à sua trama.

Outro texto de The Martians perfeitamente cabível na trilogia é o que mostra a redação final da Constituição Marciana, com seus parágrafos e incisos. Também há relatos puramente descritivos como “The Way The Land Spoke To Us” (Como Nos Fala a Paisagem) e "Four Teleological Trails" (Quatro Trilhas Teleológicas) que facilmente poderiam se somar às páginas da saga em Marte. Essa publicação do que não coube na trilogia escancara a urdidura do escritor, selecionando desdobramentos e jogando com as personagens para se montar o enredo, chegando ao final feliz (e utópico). 


\subsection{O Partido da Utopia}

Vários críticos rotulam a obra de Kim Stanley Robinson como uma ficção científica "humanista”, "ecológica” ou "progressista” - estes dois últimos adjetivos acabaram se tornando conflitantes nos nossos dias, quando o progresso é identificado como a ideologia capitalista do crescimento constante e com a destruição da natureza..

O autor da trilogia representaria uma contraposição à contemporânea onda cyberpunk, que irrompeu durante a Era Ronald Reagan (1980-1988), promovendo em suas maquinações a idéia de que a tecnologia domina o homem - nada mais instrutivo para uma época em que estava no poder um ex-ator B hollywoodiano que planejava criar um escudo de proteção antinuclear utilizando satélites que disparavam mísseis contra as hipotéticas ogivas soviéticas, no chamado projeto “Guerra nas Estrelas”.

Inaugurado por Neuromancer, livro de William Gibson que em 1984 cunhou o termo cyberspace (depois popularizado com o advento da Internet), o cyberpunk é ambientado em cenários metropolitanos, sufocantes ou virtuais. Suas personagens são seres impotentes diante das máquinas - sensação, talvez, reflexo de uma época que uniu o fim da corrida armamentista da Guerra Fria com a nascente popularização da informática e seu mundo digital.

Robinson, porém, renega os rótulos que sua obra recebeu, mas acredita que a relação do homem e da natureza com a tecnologia é uma boa forma de separar visões de mundo de cada autor. “As utopias dizem explicitamente: 'pode ser melhor', o que vai além da sátira e do derrotismo do cyberpunk", sentencia Robinson em entrevista para a revista Strange Horizons (JAMNECK, 1995). “A questão é saber se o cyberpunk é distópico ou fomentador de uma ordem social horrível, o que seria algo inteiramente diferente, algo como 'bem-vindo à máquina'”, complementa em entrevista para a publicação online especializada em speculative fiction, denominação que abarcaria a ficção científica e a literatura de fantasia nos EUA.

O caso é que Robinson usa também muita informação tecnológica e não descarta em sua obra a presença de mecanismos capitalistas, mas, ao contrário dos cyberpunks, não cria enredos noir com protagonistas deslocados e cínicos tentando livrar sua pele em alguma megalópole catastrófica. Já os mocinhos de Robinson são, em geral, cientistas que entram em conflito com o sistema e abraçam causas ecológicas ou políticas - clamando por um sistema econômico diferente, baseado em justiça social, democracia e sustentabilidade ecológica, o que já foi classificado de um "quase-socialismo”.

Montanhista praticante, o escritor advoga uma ficção científica outdoor, em outro forte contraste com seus contemporâneos do gênero, mas em harmonia com a tradição estadunidense formada por Walt Whitman (1819-1892), Henry Thoreau (1817-1862) e Ralph Waldo Emerson (1803-1882) de ligação com a natureza vasta do país. De Emerson, se escuta o eco no episódio dos caçadores em Blue Mars quando os prazeres instintivos são convocados no caminho à felicidade.

"Historicamente, a ficção científica tem sido uma literatura urbana, mas o futuro aponta para incluir como um elemento crucial a nossa relação com o planeta. Não são numerosos os livros sobre isso, só Le Guin parece ter realmente abordado isso", declara em entrevista a revista eletrônica Infinity Plus.(GEVERS, 1999).

Em outra entrevista, Robinson exibe uma diferença em relação às idéias de Jameson sobre a relação entre ecologia e política. "Ele tende a englobar o tema ambiental abaixo da noção socialista 
ou marxista de governo - o que quer dizer: se você quer ser um ambientalista, você tem que acabar sendo um socialista de qualquer forma para chegar lá”, declarou para a revista eletrônica Sci-Fi Universe. E continua na mesma entrevista de 1996: "Tenho pensado sobre utopias faz muito tempo e, olhando para o mundo em que vivemos, a discrepância entre ambos é bastante grande. Eu penso sobre política tanto quanto uma pessoa pode pensar, mas eu penso mais sobre o tema ambiental... é uma espécie de dilema do ovo e da galinha: o que é mais importante? (...) Então eu não acho que tenha a mesma certeza sobre o assunto que Jameson tem.”(BABCOCK, 1996)

No cenário político dos EUA, Robinson tende a se identificar com o Partido Democrata, principalmente no tema ecológico. Em entrevista, ele afirmou que dentro de cada SUV (Sport Utility Vehicle, carros com chassi de camionete, alto consumo de gasolina e fama de vilão no aquecimento global) nas auto-estradas do país está um republicano, que acredita que o aquecimento global é mais uma invenção democrata para criar um novo imposto e promover um "socialismo global”.

Por seu lado, o crítico literário Jameson destaca-se como uma das figuras-chave na análise da cultura contemporânea e da pós-modernidade. Tamanho é o alcance de sua obra em avanço intelectual que já se imaginou criar um campo no meio acadêmico dos EUA em torno de seus achados.

\begin{abstract}
"Essa variedade justifica que alguns dos estudiosos de sua obra - hoje são pelo menos uma dúzia de livros e mais uma centena de artigos - proponham considerálo, como faz Michael Denning, não apenas como mais um grande autor na nossa Era da Teoria, mas como um novo campo cultural. Na mesma linha, Ian Buchanan defende que, a fim de não sub-utilizar o potencial do seu legado, ele deve ser lido 'dogmaticamente, como o fundador de um discurso (para a descrição de Michael Foucault das obras de Freud, Marx e Nietzsche) ou seja, alguém cujo pensamento nos chega em forma de um sistema em que podemos nos situar e utilizar para propósitos próprios'. Eu não discordo desses autores, mas acho que pode ser mais esclarecedor pensar a obra de Jameson como exemplo da capacidade da tradição da crítica cultural materialista de produzir um pensador que possa retratar e transcender os limites da situação que o engendra” (CEVASCO, 2008)
\end{abstract}

De formação marxista, Jameson é uma avis rara nos círculos acadêmicos anglo-americanos, onde predomina o pensamento empírico, pragmático e formalista. Ele derivou para a linha materialista de interpretação depois de formular sua tese de doutorado sobre Jean-Paul Sartre (“Sartre: The Origins of a Style”, de 1961), estudando a partir daí pensadores como Georg Lukács, Ernst Bloch, Theodor Adorno, Walter Benjamin e Herbert Marcuse - este último seria seu colega na University of California na conturbada virada dos anos 60 para os 70, época de protestos estudantis, Guerra do Vietnã e dos movimentos de contracultura.

Em 1967, Jameson se transfere para o campus de San Diego. Publica em 1971 Marxismo e Forma, livro no qual mistura a linha intelectual do marxismo ocidental com a teoria que estava em voga à época, o estruturalismo. Na década de 80 , ele escreve os dois livros que lhe garantiram projeção internacional na interpretação da cultura. São eles O Inconsciente Político (1981) e PósModernismo, ou a Lógica Cultural do Capitalismo Tardio (1996) - este livro, assim como Archaeologies of the Future, que seria o derradeiro, faz parte de uma série de seis volumes cujo assunto é a poética das formas sociais, adotando uma análise literária com uma perspectiva histórica nas mudanças sociais e culturais. É por essa preocupação que Jameson se debruça em um gênero tão ignorado pela academia, como a ficção científica, percebendo nela um poder de imaginação que a chamada alta cultura perdeu há tempos.

É justamente nesse último livro que o teórico sai da tradicional posição intelectual de apenas 
analisar e criticar. Nele, Jameson esboça uma postura mais arriscada e propositiva, afinal, o assunto utópico inspira apostas. Tudo porque o crítico do pós-modernismo, que soube como ninguém desvendar o despiste por trás dele, partiu de uma avaliação que aquelas manifestações artísticas tinham muito decorativo para, com o passar dos anos, apontar que essa linha ganhou importância política e era representativa dentro do processo de globalização. Jameson esboça que a pósmodernidade pode adotar uma feição de esquerda se for acentuada a potencialidade de diálogo entre os fragmentos da civilização atual.

Engajada, a proposta dele é um cardápio federal de utopias para todos os gostos, fés e idades, podendo o sujeito trocar de utopia quando e como quiser, escolhendo a melhor da praça. Nesse contexto, o consenso dá espaço para a multiplicidade. Apesar dessa lógica do múltiplo imperar nos nossos dias de globalização (alguns preferem o termo “americanização"), Jameson defende um desvio à esquerda nessa trilha fragmentada da cultura atual, dando um sinal positivo para o que foi apresentado como negativo por toda uma tradição crítica: "Eu tenho argumentado que tal alegado relativismo oferece novos e produtivos caminhos para a história e a prática; e não há razão para temer que as utopias pós-modernas não sejam tão revigorantes em seu novo contexto histórico como as velhas utopias foram nos séculos prévios.” (2005, p. 212)

Jameson, porém, vê algo mais importante que o fecho que Robinson dá a seu relato: o papel motriz das utopias. O crítico vislumbra uma diferença essencial entre a trilogia marciana e os textos utópicos anteriores, mais preocupados em "oferecer esquema de mudança, projetos de prédios das novas sociedades e até guia de viagem sobre elas”, ironiza. De acordo com Jameson, a trilogia de Robinson é "o único exemplo de uma nova tendência formal, na qual não é a representação da utopia, mas sim o conflito de todas as possíveis utopias, (...) que se move para o centro das atenções.”

O lado positivo disso é privilegiar a discussão, o debate na formação discursiva desse futuro, no lugar de um salvador ou um gênio da raça a resgatar a humanidade (o acento está na feitura e não no resultado da utopia). O lado negativo é verificar uma balcanização da esperança: em um tempo que as diferenças falam mais alto que a identificação entre os homens, até mesmo imaginando um futuro bom. Jameson, porém, acredita no impulso utópico dentro de cada grupo, para superar o estágio limitador da micropolítica e suas ocasionais e pequenas conquistas.

Passado o boom da ficção científica, ultrapassada em popularidade pelo gênero fantasia $a$ la Harry Potter e O Senhor dos Anéis na virada do século 20 para o 21, o caminho dos homens do futuro, com seus robôs, andróides e aliens, não seria criar utopias, mas fazer com que elas voltem a ser imaginadas. "A utopia como forma não é a representação de alternativas radiciais, mas sim simplesmente o imperativo de imaginá-las", argumenta Jameson na última frase de sua resenha sobre o livro de Robinson, chamada “If I Find One Good City I’ll Spare The Man': Realism and Utopia in Kim Stanley Robinson's Mars Trilogy” (Se Eu Encontrar Uma Cidade Boa Eu Salvarei o Homem, Realismo e Utopia na Trilogia Marciana de Robinson), também presente em Archaeologies of the Future (2005).

Nas suas palavras, Jameson prefere pensar a utopia como "um destino pouco usual de uma forma literária” que acabou virando tema político. Antes de analisar as versões atuais, o teórico expõe em seu livro a tradição que começou em 1516 com Thomas More e a publicação de Utopia, passando pelas derivações imaginadas nos séculos seguintes. E, como esse tipo de literatura imagina lugares distantes no tempo e/ou espaço, acabou engolfada pelo gênero ficção científica, que surgiria só no século 19 após a Revolução Industrial - analistas divergem sobre o livro fundador, uns apontam Frankenstein (1818), de Mary Shelley; outros preferem A Máquina do Tempo (1895), 
de H.G. Wells. A chamada sci-fi (corruptela de science fiction) atravessou com obras reveladoras de seu tempo o período imperial europeu, sua decadência, a ascensão dos regimes totalitários, os grandes conflitos mundiais, a posterior Guerra Fria e chegou agora ao período de globalização imposto pela superpotência dominante.

Vários autores concordam que o pensamento utópico surgiu como efeito da ebulição típica do Renascimento e da Reforma (séculos 16 e 17), épocas de grandes mudanças que promoviam e excitavam a imaginação dos homens. Relatam, porém, que sofreu forte influência de duas tradições idealistas anteriores. De um lado está a Bíblia e a idéia judaico-cristã de paraíso divino (existe a premissa muito aceita que as utopias são versões laicas do Jardim do Éden). Seguindo o mesmo raciocínio, as distopias constituem infernos em que o diabo muda de figura - segundo Frank e Fritzie Manuel, "as histórias da utopia e distopia constituíram uma paisagem parecida a um claroescuro”. (1984)

Na outra matriz, se coloca a escola helênica de imaginar a cidade ideal dos homens, cujo exemplo mais famoso está em A República de Platão - a tradição grega de descrever Estados ótimos influenciou diretamente no século 18 os textos alemães e franceses classificados como Staatsromane, exemplos de países harmônicos. Os filósofos da Grécia pensaram em problemas concretos do tipo organizativo. A trilogia de Robinson também tem esse viés, dando destaque para a pragmática engenheira Nadia e para seu parceiro amoroso e auxiliar administrativo Art, um gerente da corporação Práxis.

Platão, em A República, estabelece que normas e instituições dos homens não podem ficar na esfera religiosa ou mágica, mas sim na da política. Comparativamente, na trilogia marciana, Robinson faz uma opção pelo gerenciamento (a palavra da moda seria management) de Nadia e Art em detrimento da espiritualidade de Hiroko ou o idealismo revolucionário de Arkadi.

Dessa origem meio bíblica, meio grega, pode-se depreender que o maneirismo de estilos e a fusão de idéias são tônicas na trajetória utópica, o que ajuda a entender a eleição de Jameson e Robinson por misturar o ideário de esquerda com uma formatação pós-moderna, hoje a serviço da ideologia conservadora, como o próprio Jameson cansa de apontar em seus textos - esta seria uma das bandeiras (outra, por exemplo, é o universalismo) que a se tirar das mãos da direita.

Essa postura de Robinson de apresentar várias utopias sem destacar uma pode ser interpretada, por outro lado, como uma falta de adesão completa a um projeto (ou, mais causticamente, um relativismo típico de certa esquerda). Em El Pensamiento Utópico en el Mundo Occidental (1984), os autores Frank e Fritzie Manuel contam que o período justamente anterior à Reforma viveu um surto de utopias desencontradas como as de agora: "Antes do cisma da Reforma, os humanistas cristãos eram assaltados por dúvidas, crenças em conflitos e lealdades opostas. E foram suficientemente cândidos como para expressar suas apreensões e ambivalências, colocar sobre o tapete os paradoxos, dizer uma idéia sem por isso abraçá-la por inteiro, e chamar a atenção sobre um mau presente propondo um aventurado remédio, como pode ser a utopia, e logo deixar de defendê-lo" (p. 194). Robinson também fala de muitas idéias futuras sem aderir a nenhuma por inteiro, defende, descarta ou coloca como opção. Em parte, isso se deve ao fracasso da experiência soviética. Por outro lado, está o clima triunfante do capitalismo, que não convence a esquerda norteamericana, como a do mundo todo. De qualquer forma, a urgência de teorizar a respeito é grande, afinal, é preciso desvendar a atualidade para saber para que lado ir (fazer o cognitive mapping, nas palavras de Jameson).

Em Archaeologics of the Future, Jameson reserva um capítulo para falar da Utopia de More e 
parte direto para a tradição já sob o comando da ficção científica. O foco do teórico norteamericano é o cenário das últimas décadas. Seu livro é dividido em duas partes. A primeira, intitulada “The Desire Called Utopia” (Um Desejo Chamado Utopia), reúne textos mais teóricos fazendo um panorama histórico do assunto e ainda versando sobre suas conexões com o desejo, os temores (da violência, da perda da individualidade, do tédio), o tempo, o espaço, o corpo, etc. Já a segunda parte, chamada sugestivamente de “As Far As Thought Can Reach” (Até onde o Pensamento Pode Chegar) é uma coleção de ensaios e resenhas que ele publicou sobre ficção científica desde a década de 70, incluindo debates sobre as obras de Charles Fourier, Brian Aldiss, Ursula L e Guin, Phillip K. Dick e Robinson. 


\subsection{Economia literária}

É curioso ver que, da mesma maneira que em relação à utopia proposta pelo próprio Jameson, citada na segunda página deste trabalho, Robinson cumpre em sua trilogia também um dos mandamentos utópicos de More [o fim da propriedade privada, com exceção da corporação Práxis, mas relega o outro ditame (a extinção do dinheiro)]. Em seu planeta vermelho, lá está o sequin (grafia em inglês para zecchino, moeda que circulou de 1284 a 1797 em Veneza, principal berço da primeira forma de capitalismo).

O dinheiro marciano é citado de passagem em dois trechos do último livro - na primeira vez, retratando a preocupação de uma especulação sobre a divisa; na segunda, em uma cena em que o garçom apresenta a conta durante confraternização pela terceira revolução em Marte. Aliás, duas cenas claramente inspiradas em fatos dos anos 80 e 90: 1 - As crises cambiais geradas pelos capitais flutuantes dos grandes financistas (como o Black Monday, dia em 1987 que a bolsa de Nova York tivera a maior queda desde a crash de 1929, mas que foi inferior à queda de 2008); 2 - As manifestações populares nas revoluções de veludo que deram fim aos regimes comunistas no Leste Europeu (começando com a abertura soviética e a queda do muro de Berlim em 1989).

Jameson lembra que More pôde imaginar um mundo sem dinheiro porque havia em sua época os monastérios na Inglaterra em que a vida era levada sem necessidade e o intermédio de moedas e cédulas. Já Robinson prefigura um enclave similar nos primeiros anos de colonização de Marte, quando os cientistas, pela quantidade de trabalho a realizar e pelas diminutas dimensões de sua cidade (Underhill), vivem em uma espécie de laboratório monástico. O vibrante socialista Arkadi resume esse início idílico em conversa com sua parceira Nadia:

\footnotetext{
“Meio ano. E durante todo esse tempo em realidade não tivemos líderes. Essas reuniões noturnas em que todos falam o que pensam e o grupo decide o que é necessário fazer; assim que tem que ser sempre. E ninguém perde tempo comprando ou vendendo, porque não há mercado. Tudo aqui pertence a todos por igual. E, mesmo assim, ninguém pode explorar nada que lhe pertença, pois não há ninguém lá fora a quem vender. Foi uma sociedade comunal, um grupo democrático. Um por todos, e todos por um.” Ao que Nadia replica: “As coisas estão mudando. Já não são assim” (1993, p. 167)
}

Em um outro trecho, quando a conversa é com John Boone, Arkadi dá uma visão mais histórica à mesma tese: "Uma estação científica é na realidade um modelo de utopia pré-histórica, arrancada da economia monetária das transnacionais por primatas inteligentes que desejam viver bem.” Mas isso, claro, escancara o caráter de enclave dessa utopia, apesar do objetivo de Arkadi que quer ampliar esse cenário (a idéia de enclave utópico desaparece na conclusão da trilogia, afinal, não há uma cidade exemplar para servir de regra geral, o que nesses tempos seria interpretado como uma "falta de imaginação" ou um "excesso de dogmatismo").

O próprio Jameson diz que a extinção do dinheiro, que, além de More, foi imaginado como panacéia também por Platão, traria nos dias atuais mais problemas que soluções. Em sintonia com o mestre, Robinson prefere não mexer nesse vespeiro, e a questão do dinheiro é rebaixada em sua obra, aparecendo cá e acolá, como, quando ao final da viagem interplanetária dos pioneiros, Maya descreve Marte com metáforas monetárias. Primeiro, a russa diz que, desde a nave Ares, o planeta é do tamanho de um dime (moeda de dez centavos de dólar). Dias depois, já é do tamanho de um quarter (moeda de 25 centavos de dólar). 
Também a presença de árabes e suíços se deve, em parte, ao dinheiro que eles têm. Os suíços, para ilustrar, cumprem o papel de financistas no meio da população marciana, além de servir também como um exemplo de federalismo - John em seu computador, batizado de Pauline, pesquisa sobre a administração estatal de lá, que forma um sistema que evita governantes carismáticos.

Na visão de Jameson, o capitalismo tardio está cumprindo o desejo de desaparecimento do dinheiro. Como sua versão artística, a pós-modernidade, o capital financeiro trabalha com transações cada vez mais abstratas e voláteis. Em um mundo de cartões de crédito, pagamento por celular e débitos automáticos, “será que o dinheiro já não foi abolido?”, se pergunta Jameson.

Não por nada os termos volatilidade, flutuações e liquidez são usados atualmente mais em textos de economia que de química, sua origem. Mas essa fluidez toda do crédito ilimitado, alimentando o consumo desenfreado e empresas alavancadas, deu na atual crise global, e o cenário de futuro róseo de crescimento constante se esfumaçou.

Esses mesmos investimentos e especulações "neutralizam" o futuro, "contabilizam o desconhecido", nas palavras de Jameson, que parafraseia George Orwell e Walter Benjamin (1985) para ilustrar a importância do pensamento utópico para lutar contra essa realidade. O teórico norteamericano toma a ansiedade de perder o passado, a memória e a infância expressa pelo escritor inglês e troca sua chave: para ele temos que desenvolver uma ansiedade de perder o futuro que seria análoga à ansiedade de Orwell. Além disso, ele adapta uma das máximas nas teses de Sobre o Conceito de História do pensador alemão "Se Benjamin diz que nem mesmo os mortos estarão a salvo dos conquistadores, nós podemos dizer que nem mesmo o futuro estará também”.

Por isso, Jameson apresenta a lógica utópica no ensaio “The Future as Disruption” como a maneira de descolonizar a imaginação e fazer com que o futuro não seja o presente tornado eterno. "Não é mais a exibição de uma utopia alcançada, mas a história de sua produção e o processo de sua construção como tal”, sentencia o crítico, dando pista do porquê de a trilogia de Robinson ser tão extensa. O título do ensaio é tão emblemático para a proposta: "Pensar o rompimento, não oferecer um quadro de como será depois da ruptura.” Ou seja, os intelectuais não vão resolver o problema, mas redefini-lo.

O próprio Robinson confessa como principal dificuldade na elaboração da trilogia abrir um caminho em direção à utopia. "É mais fácil imaginar um sociedade radicalmente diferente (...) $\mathrm{O}$ duro é imaginar qualquer maneira plausível de chegar de aqui até lá”, declara em entrevista para a revista Science Fiction Studies (FOOTE, 1994). E esse trabalho árduo de criação, nas palavras do escritor, está relacionado com a "sensação de perpétua novidade na vida dos dias atuais, onde qualquer coisa é possível (...) Por outro lado, há o sentimento que nada fundamental irá mudar de novo”. Em outras palavras, uma época em que tudo é imaginável, menos as utopias.

Na mesma entrevista, o ficcionista deixa ainda mais explícito o que é patente em toda ficção científica: os enredos distantes no tempo e no espaço estão pautados pelo "aqui e agora” do escritor. "Meus romances sobre Marte foram escritos com a idéia de que eles são metáforas descrevendo o que nós necessitamos fazer aqui também.” Todo o esforço científico para realizar a transformação de Marte em um lugar habitável reveste o desejo de tornar a própria Terra habitável para a humanidade, talvez pela primeira vez na história, afinal, até hoje o solo terrestre se mostrou um ambiente hostil às sociedades igualitárias.

Para além da presença do dinheiro, Robinson, apesar das propostas alternativas como a eco- 
economia, a economia do presente e as cooperativas, não consegue projetar um futuro sem a presença de grandes corporações capitalistas.

A Práxis é a empresa redentora entre as chamadas metanacionais, pessoas jurídicas do futuro próximo que dominarão nações pequenas e médias, rivalizarão com os grandes países e tentarão a hegemonia sobre Marte. Essas metanacionais seriam uma versão ainda mais agigantada e invasiva das empresas transnacionais, que, por sua vez, são uma forma "avançada" das atuais multinacionais - para ilustração: o termo "metanacional” já é empregado na atualidade, com outra definição (empresas que não dependem mais da lógica do mercado nacional), e a fabricante de celulares Nokia seria o maior exemplo disso (de origem finlandesa, divide seus departamentos por todo mundo: miniaturização no Japão, design na Inglaterra, interatividade na Califórnia etc.)

Robinson marca essa mutação de multinacionais para metanacionais (ou a corruptela metanacs) por meio de uma nomenclatura que satiriza o processo de fusão das empresas, tão comum há dez anos quando ele escreve como agora. No começo de Red Mars, lá estão as "verídicas" G.E., Westinghouse, Mitsubishi, Boeing, Portland, Amex, Mercedes-Benz, Volvo e John Deere, como fornecedoras de equipamentos para a exploração de Marte (veículos, escavadeiras, exaustores, reatores etc.) e com interesses na economia local. No entanto, no decorrer aparecem empresas com nomes enxertados como Subarashii (poderia ser uma mistura de Subaru com Hitachi) ou Shellalco (Shell com Texaco). Ou nomenclaturas que soam exóticas, como Oroco, Consolidated ou Armscor.

Já o termo Práxis tem origem aristotélica - era o que o filósofo definia como a atitude engajada dos homens livres na Grécia Antiga. Porém, é seu emprego na teoria marxista que deu sentido renovado ao conceito, dentro da idéia de Marx que a filosofia devia deixar de só interpretar o mundo e passar a ser um instrumento de mudança dele.

Na trilogia, a metanacional “do bem” Práxis encerra a história patrocinando a pesquisa na cidade marciana de Da Vinci para que se crie uma tecnologia que recupere a memória dos bicentenários pioneiros do planeta vermelho. Ou seja, o escritor não vislumbra nos próximos dois séculos uma ciência que não tenha por trás o capital - se o dinheiro rege nosso consciente atual, pelo menos, segundo Freud, está ausente de nosso inconsciente, como lembra Jameson (2005, p. 18). De qualquer forma, esse tal capital esclarecido, ilustrado e representado pela Práxis tem uma semelhança (de "mera coincidência") àquele das empresas com o prêmio de responsabilidade social, ecológica ou um selo ISO 9000. O chefe da Práxis, William Fort, também banca um encontro anual para discutir a eco-economia do "marxista” Taneev.

Quando explica a economia por seu ângulo, o capitão de indústria mistura noções de biologia, física e ecologia com conceitos como capital humano, capital natural, energia renovável, bio-infraestrutura, economia de mundo cheio e ICF (Índice de Crescimento Futuro). Em sua entrada no congresso de Dorsa Brevia, comparada à aparição da mística Hiroko, Fort traz toda essa carga teórica para debater com as teorias marcianas de economia (no final múltiplo da trilogia, nenhuma dessas teses econômicas acaba por se impor).

A Práxis está totalmente inserida na lógica capitalista da competição de mercado. No enredo, ela adota uma estratégia arriscada para conquistar seu espaço diante das concorrentes. E o chefe dela surge como mais um gigante do escritório de patentes do capitalismo, como Graham Bell ou Bill Gates.

Em seu discurso, Fort compara o capitalismo ao feudalismo, mesma formulação defendida 
por John Boone em discurso e por Robinson em entrevista, o que mostra as múltiplas posições que uma mesma idéia pode aparecer. Práxis se apresenta como uma exceção entre as metanacs, uma mutação à esquerda (fala-se em "comunismo corporativo”), algo que parece estranho, afinal, não é de se esperar que aqueles que detêm um poder abdiquem dele, que a mudança venha de quem é beneficiário da continuidade. Mas a pessoa jurídica teria mudado da água para o vinho como algumas pessoas físicas do livro.

Um modo de produção radicalmente novo exige relações sociais radicalmente novas, por isso o sistema de produção do planeta Marte de Robinson é uma continuação aprimorada do atual, dando espaço para formar alternativas (como cooperativas) e limando sua faceta mais fundamentalista (a colaboracionista Phyllis Boyle reproduz em suas falas os clichês capitalistas, como o de crescimento constante: “A fé e a ciência continuarão criando novas oportunidades.” E seu assassinato marca a exclusão desse estilo de capitalismo).

Outro indício que o sistema não foi abandonado é a própria eleição para presidente de Marte. Estabelecido pela Constituição, o pleito adota a mesma espécie de concorrência política da democracia ocidental de nossos dias, com campanhas publicitárias e ataques pessoais entre os candidatos (em Blue Mars, Maya concorre com Jackie em uma corrida eleitoral para o Conselho Executivo em que usa de expedientes pouco éticos para vencer, como abalar emocionalmente a rival convocando Peter e o jovem Athos e também lembrando-a da morte de sua filha, Zo. E, no final, vence a eleição.).

O próprio Jameson, em sua crítica específica à trilogia, aponta que o ficcionista revestiu com muita simpatia a empresa fictícia, apesar de afirmar que Marte de Robinson é "anticapitalista”. Outras empresas como a Biotique e a Séparation de L'Atmosphère também passam no crivo de Robinson e são membros atuantes na constituinte marciana do último volume. Se as empresas e as pessoas mudam ou não, isso é assunto para uma análise dos elementos da narrativa da trilogia e para um outro capítulo.

Por outro lado, as alternativas econômicas criadas pelas personagens de Red Mars não são suficientemente completas para garantir a inauguração de um novo modo de produção e entram na lógica federativa de utopias. E, em geral, elas estão mais voltadas para um tipo de comércio nãolucrativo.

É o caso da gift economy que Robinson traz da antropologia para sua ficção científica (antes Le Guin fez importação similar em The Dispossessed). O conceito tem várias traduções para o português: economia do presente, da dádiva, do dom, da adoção ou da comunhão. A idéia principal desse sistema econômico de benefício comunitário é que o potencial lucro seja passado para frente na negociação (não necessariamente uma troca), não ficando retido por quem acrescentou valor agregado ao bem ou produto.

O Coyote conta como dentro da própria resistência pós-2061 há uma dificuldade em assimilar os princípios da economia do presente. "Estou liberando as pessoas de sua ridícula noção de economia, isso o que eu estou fazendo! A economia do presente está muito bem, mas não está suficientemente organizada para nossa situação atual. Há artigos essenciais que todo mundo necessita, e as pessoas têm de dá-los, o qual é uma contradição, não é? Por isso, estou tentando criar um sistema racional. Ou melhor, Vlad e Ursula são quem estão elaborando, mas eu tento aperfeiçoar, o que significa que eu levo todas as queixas” (1994, p. 59).

O sistema de economia do presente teria como um certificado de procedência, afinal, descenderia de uma origem pré-capitalista (é registrado em culturas asiáticas, da Oceania e da 
América pré-colombiana), com uma lógica quase espiritual (o presente como dádiva) e ainda seria aprimorada por cientistas na atualidade - esse tipo de negociação é mais palpável no ambiente acadêmico, no qual a circulação de uma informação ou descoberta é mais valorizada que sua retenção por parte do autor.

Um dos incentivadores dessa economia são os sufis, comunidade de origem iraniana que pratica um islamismo sincrético com religiões anteriores a Maomé. Uma mulher dessa crença explica os valores dela para John Boone, que acaba de sair do transe hipnótico da dança dos derviches giróvagos, ao som de "Ana el-Haqq, ana Al-Quahira”, frase em árabe que quer dizer "Eu sou Deus, eu sou Marte”. (1993, p. 315)

\begin{abstract}
“É um pequeno sinal de que estamos juntos - disse a mulher mais velha - Lá estávamos as velhas culturas antes que vosso mercado global envolvera tudo em uma rede: naquelas épocas havia muitas formas de intercâmbio. Algumas consistiam em presentear coisas. Olha, todos temos um presente que nos foi dado pelo universo. E todos nós cada vez que respiramos devolvemos algo em troca.

- Como a equação de eficácia ecológica - disse John

- Talvez. Em qualquer caso, surgiram culturas inteiras ao redor do conceito de dom, na Malásia, no noroeste americano, em muitas culturas primitivas. Na Arábia, dávamos água e café. Comida e albergue. E tudo o que te era dado não pretendias retê-lo, e sim dá-lo outra vez. Se possível, com juros. Trabalhas para dar mais do que havias recebido. Talvez essa poderia ser a base de uma economia reverente.

- É o mesmo que dizem Vlad e Ursula!”.
\end{abstract}

O trio médico-economista Vlad, Ursula e Marina elabora a chamada eco-economia a partir de uma equação entre calorias consumidas e produzidas por cada pessoa. Para explicá-la, Marina faz uma interessante análise (1993, p. 299) do papel dos executivos na sociedade atual, comparando-os aos grandes predadores no topo da cadeia alimentar, mas para dizer que eles ocupam muito espaço e produzem pouco - ela também fala que a metáfora dos tigres é ideal para as nações ricas na Terra, afinal, esses felinos precisam dominar um grande habitat para produzir pouco.

\begin{abstract}
"Há uma infinidade de trabalhos fantasma! Valores irreais assinalados para a maioria dos trabalhos! A classe executiva transnacional não faz nada que um computador não possa fazer, e há categorias inteiras de trabalho parasitário que não aportam nada ao sistema segundo a valorização ecológica. A publicidade, a especulação, todo o sistema de fazer dinheiro manipulando dinheiro. Não só é um desperdício como, além disso, corrompe; os valores significativos do dinheiro se distorcem com tal manipulação - e sacudiu a mão em sinal de desgosto.”
\end{abstract}

O trio da resistência calculou até como o ócio e a educação contribuem para o sistema de trocas de calorias, em pesquisa com os outros cientistas de Acheron, com gráficos, cálculos e simulações (algo similar ao mercado de créditos de carbono, criado pelo Protocolo de Kioto de 1999). Os três montaram um "taylorismo do bem”, desprezando o lucro e privilegiando a eficiência, mas, mesmo assim, não foi o suficiente para a unanimidade da fragmentação do livro de Robinson.

Ainda na resistência, é descrita uma economia monetária em que o sistema de compra e venda é feito por unidades de peróxido de hidrogênio ou usando o "padrão nitrogênio", no lugar de cédulas. Robinson também pinça experiências econômicas como as cooperativas de Mondragon (empresa basca fundada em 1941, mas que se adaptou aos tempos de globalização, mantendo-se propriedade de seus trabalhadores).

Em entrevista para a revista Sci-Fi Universe (BABCOCK, 1996), o autor da trilogia conta que colocou Vlad na linha de herança de Karl Marx, ao comentar seu discurso durante a Constituinte 
marciana, mas que ele, Robinson, não descartaria o mercado em sua utopia: "[O discurso de Vlad] é uma clássica análise marxista dos problemas do capitalismo, e então dá soluções que, eu penso, não foram as tentadas até agora sob a bandeira marxista, e isso é bom. E também eu respeito a noção que ainda poderia existir algum tipo de mercado, no qual você não queira um controle externo e completo. Então, a idéia de cooperativas, de uma economia mista e de uma espécie de socialdemocracia, são atraentes para mim.”

Robinson arquiteta uma utopia com o melhor de todos os mundos existentes: as comodidades do capitalismo, a segurança do socialismo, a flexibilidade do liberalismo e as festividades do mundo primitivo. Nessa mistura, há no fundo uma utopia do consumo ilimitado de todos os prazeres orais e genitais, pregando o fim dos monopólios e o crédito fácil para gozar as delícias do mundo. Isso lembra a história presente em Pantagruel, de Rabelais, que conta da "maravilhosa cidade dos endividados felizes" (uns deviam para os outros, fechando um círculo vicioso ou virtuoso), o que ilustra o gosto daquela época por usar o artifício literário que é o paradoxo - o que é impossível na sociedade projetada por Robinson, afinal, no pot-pourri de utopias tudo é possível, nada é conflitante.

A ficção científica é uma literatura de idéias, e nos livros de Robinson elas se multiplicam a olhos vistos. Mas, na lógica da fragmentação pós-moderna, toda boa idéia deixa de sê-la quando vira regra geral. Logo é etiquetado como dogma, autoritário e homogenizante. Então, seguindo esse raciocínio, a melhor solução seria uma utopia que seja um show-room de formas de governo, economias e sociedades, preservando a diversidade dentro da coletividade.

Por isso, Robinson trilha um caminho, já apontado por pensadores que vão da direita (Carl Schmitt) à esquerda (de Hannah Arendt a Slovaj Zizek), de recuperação do diálogo político em um contexto histórico em que só existe o monólogo econômico - o escritor norte-americano prefigura esse embate com as guerras entre as corporações terráqueas e os vários partidos marcianos. Essa revalorização da política seria a forma de aplacar a hegemonia que a economia (leia-se capitalismo) detém sobre todas as áreas humanas e naturais, relegando os políticos a sua atual "desimportância”

Devido a esse cenário, o idealista atual não parece aquele que acredita em uma sociedade perfeita, mas aquele que sustenta que o futuro será uma edição melhorada do presente, como na solução conciliatória no desfecho da trilogia marciana. É o tal do destino possível, factível, o que pode ser encarado como uma limitação da imaginação ou a razão prática das utopias.

Em épocas como a nossa, o utopista é tratado como um obsessivo monomaníaco e megalomaníaco, um pseudovisionário de fantasias etéreas e desconectadas da realidade. Contudo, em tempos de grandes mudanças (como o Renascimento, a Reforma ou os períodos quase simultâneos da Revolução Industrial e a Francesa), quando tudo parece possível, os utópicos não são tachados como desvairados, como acontece em tempos de estagnação social e intelectual como os da atualidade.

\footnotetext{
${ }^{2}$ Apesar de saber da preponderância da economia, como bom pensador marxista, o próprio Fredric Jameson faz coro e pede a volta da discussão política, o que só acaba acontecendo em momentos de grave crise econômica como ocorreu em 2008, com a quebra de bancos e seguradoras dos EUA e da Europa, o que obrigou os governos a debaterem, mas a conversa cai sempre em decisões puramente financeiras. “As utopias são expressões sintomáticas do desejo não de uma política futura, mas do retorno do político ao momento contemporâneo, de onde foi evacuado”, escreveu o teórico na revista New Left Review (edição de janeiro/fevereiro de 2004).
} 


\subsection{O utópico e a ficção científica}

Se se pode falar em uma "utopística”, o conceito nasceu primeiramente como versão literária com uma publicação de 1516 que tinha no frontispício o seguinte: Sobre a Melhor Constituição de uma República e a Nova Ilha de Utopia - Um Livrinho de Ouro, Divertido e não menos Edificante, De Autoria do Ilustríssimo e Sumamente Eloqüente THOMAS MORE, Cidadão e Xerife da Famosa Cidade de Londres. Mas na obra posteriormente conhecida simplesmente como Utopia (1999), apesar de ser o relato do fictício viajante português Rafael Hitlodeu, há vários trechos de considerações e apresentações que parecem um tratado humanista, ao estilo de seu amigo e influenciador Erasmo de Roterdã. Na sua trajetória de cinco séculos, a utopia esteve na maioria do tempo em seu campo teórico e livresco, mas viveu seu momento de “utopística aplicada” entre o final do século 18 e o começo do século 19, em figuras como Saint-Simon, Robert Owen e Charles Fourier.

Até mesmo Karl Marx, que polemizou com as teorias deles e argumentou que seu comunismo era científico para diferenciá-lo, tinha uma forte componente utópica em seus lemas como "livre desenvolvimento do indivíduo”, “só em comunidade é possível a liberdade pessoal” ou "de cada um segundo as suas possibilidades, a cada segundo as suas necessidades" (slogan inspirado em frase similar de Saint-Simon). Mas Marx não fundou a crítica aos utópicos: o pensador Francis Bacon (1561-1626) foi um dos primeiros a mofar desses ideais poucos meses após a publicação do livrinho de More.

As utopias novelísticas da segunda metade do século 19, período em que surge a ficção científica, foram muito inspiradas em teorias dos utópicos - News From Nowhere (Notícias de Lugar Nenhum, 1891), de Williams Morris, descreve um futuro com uma "religião da ciência” muito similar a preconizada pelo pai do positivismo, Auguste Comte.

Anteriormente, Comte fora um dos influenciados pelo precursor Henri de Saint-Simon (17601825), pensador de origem nobre que aderiu à Revolução Francesa, em 1789, e foi perseguido no período do Terror. Depois desse período turbulento, ele passou a escrever sua obra, que reverencia cientistas e industriais à cabeça de uma sociedade ideal. Para montar sua utopia, Saint-Simon adotou uma subdivisão de tipos psico-fisiológicos do fisiologista Marie François Bichat (17711802), nos quais predominavam as qualidades motoras, racionais ou emocionais. Isso deu margem a que as classes sociais sejam admitidas com base dessas naturezas, cada um com sua função dentro da sociedade.

Outra grande figura da utopística aplicada é o britânico Robert Owen (1771-1858). Filho de artesões, ele enriqueceu com a industrialização e com o casamento com a herdeira das fábricas New Lanark, onde aplicou avanços para a época, como jornada de trabalho reduzida e escola para as crianças dos operários. Suas idéias de mudar o modo de produção para beneficiar o operariado, propagadas por toda Europa, acabaram caindo no vazio quando a classe burguesa se atesourou dos dividendos da Revolução Industrial. Ele tentou exportar suas idéias para os EUA, fundando no estado de Indiana a colônia de New Harmony, que depois de anos de prosperidade decaiu. Escreveu o livro The Revolution in the Mind and Practice of the Human Race em que formula a pergunta "O que se deve fazer?”, uma das preferidas dos utópicos do século 19.

Diferentemente das cidades industriais de Owen, com disciplina militar para controlar hordas de desempregados, a utopia de Charles Fourier (1772-1837) era moldada por economia radicalmente humanizada sobre uma complexa série de desejos. Fourier criou um formato de 
cidade-edifício ideal, chamada falanstério, com as 810 combinações entre os 12 temperamentos catalogados para criar um ambiente de cooperação (diametralmente diverso dos tempos atuais em que os reality shows reúnem variados perfis para acirrar a concorrência entre eles).

Vivendo como pequeno comerciante, Fourier escreveu uma obra crítica que descreveu a corrupção do comércio e da especulação - já a utopia montada em Marte por Robinson dá espaço para o "especulador do bem” William Fort, dono da Práxis, que articula com a resistência para conquistar o mercado (um "case” de sucesso, pelo seu ponto de vista).

Influenciado pelas concepções de Fourier, o pensador anarquista Pierre-Josep Proudhon (1809-65) forjou uma utopia sem Estado, sem coação nem grandes empresas (como a frase célebre dele indica: "toda a propriedade é um roubo"). Mas a sociedade ideal do francês possui alguma conexão com a de Robinson, principalmente nos aspectos liberais e resíduos multiculturalistas que esta última tem.

O multiculturalismo despontou nos países ricos nos anos 1970, encerrado o processo de descolonização da Ásia e África. Nos EUA, estava restrito a alguns setores do meio acadêmico e do artístico até que, com a aceleração do processo de globalização, ganhou o primeiro plano. O que era um movimento pela diversidade acabou ganhando um acento político de defesa das chamadas minorias (negros, mulheres, homossexuais, latino-americanos, sino-americanos, native Americans etc.) e o reconhecimento das diferenças identitárias virou bandeira de luta de grandes setores progressistas do país, contra o que chamaram de "etnocentrismo" da sociedade branca. Passado o furor multiculturalista da última década do século passado, até hoje se vê efeitos, principalmente nas ciências humanas, tanto dos EUA como também do Brasil. Um exemplo: a cultuada série de TV Jornada nas Estrelas, o produto de ficção científica mais consumido no mundo, ganhou dezenas de teses sobre seus personagens étnicos, como o capitão indígena no comando da nave espacial, além de negros, asiáticos, escoceses e russos - sem falar dos vulcanos e outros povos siderais.

“Condenemos todas as exclusões” era um dos lemas de Proudhon. Essa postura fala ao momento atual de multiplicidade e tolerância, o que tem reflexo na federação de utopias de Robinson - em comum, anarquistas e liberais têm sua pouca tolerância a autoridades estatais.

Sem Estado ou grandes corporações, o mútuo consenso geraria o sentimento de comunidade para Proudhon. A receita dele se resume a três ingredientes: educação, crédito livre e livre associação. Por um lado, transações voluntárias no lugar da intervenção estatal. Por outro, unidade econômica em vez de centralização política, o que guarda um paralelo com o proposto por Jameson (fim das taxas não parece lema de empresários liberais sobre o peso dos impostos?). A história da livre associação se assemelha à livre circulação de trabalhadores proposta pelo ensaísta norteamericano e também ao livre trânsito entre utopias de Robinson.

Por outro lado, a ajuda mútua dos primeiros anos de Marte lembra o ideal anarquista de Proudhon. Essa mistura de ojeriza às regras e autoridades une liberais e anarquistas. E um episódio na vida de Proudhon exemplifica suas diferenças com os marxistas. Em carta datada de 17 de maio de 1846 dele para Marx, após o encontro entre os dois, em que o francês se coloca à disposição do movimento do alemão desde que não se converta a revolução em uma "nova religião dogmática": "Não devemos nos converter em chefes de uma nova intolerância nem pretendamos ser os apóstolos de uma nova religião, mesmo que se trate de uma religião da lógica e da razão. Reconheçamos e incentivemos todos os pontos de vista diferentes.” Marx e Proudhon romperam depois.

Pois, incentivar todos os pontos de vista é o que Robinson mais faz em sua trilogia marciana, 
até mesmo uma nova religião. A utopia positivista de Comte também inventou um culto, mas este tão real que acabou criando igrejas mesmo no Brasil (até hoje existe no Rio o templo positivista). No que se assemelha à personagem Hiroko, Comte criou uma religião em que se auto-intitula seu sumo sacerdote. No culto, homens que realmente viveram eram cultuados como deuses, reverenciando em seu altar mestres da ciência, filosofia e até das artes, como Dante Alighieri. Comte chegou a marcar no calendário o ano de 1927 como a data para a regeneração positivista do Ocidente, uma espécie de Juízo Final da escola. O posto de comando da ordem futura comteana caberia aos capitalistas, visto que, segundo ele, sabiam controlar a riqueza e por serem dotados por natureza para a "arte da manipulação". Estabelecida a meta moral dessa sociedade, os capitalistas e os cientistas atuariam "harmoniosamente". E eles seriam como pais para seus filhos proletários, que estariam "irmanados pelo amor".

Logo essa onda de teoria utópica passou para o mundo livresco das "belas artes”, e esse viés de sonho misturado com avanços científicos acabou passando da filosofia para a literatura em um novo gênero: a ficção científica. ${ }^{3}$

Os iluministas acreditavam que instituições aperfeiçoadas e a investigação científica iriam erradicar o que há de desumano, conquistar a natureza e reduzir a incerteza. Mas o divórcio entre Revolução Industrial e Revolução Francesa mostrou que os avanços tecnológicos e civilizatórios não precisam vir necessariamente juntos, e esse distanciamento é o ato político fundamental da era burguesa.

A implementação de uma sociedade com instituições e ciências avançadas acabou ficando só nas linhas da sci-fi, gênero que parte de hipótese fictícia ("literária”), que se desenvolve com um rigor total ("científico"). ${ }^{4}$

A própria academia passa a classificar o gênero como “literatura de pensamento utópico”. E as utopias dentro da sci-fi podem ser de diversos cortes: militares, arquitetônicas, cristãs, comunistas, budistas, anarquistas, vitorianas, sexuais, infantis, apocalípticas, paradisíacas, fisiocratas, didáticas, simbólicas, higiênicas, químicas e também pós-modernas, como a que Robinson criou.

A utopia se desloca na ficção científica para lugares como o corpo alienígena. E, nesse aspecto, o exemplo de Nirgal é didático. Encarnação da utopia como os outros ectógenos, gestados em tanque de magnésio, ele tem o corpo já adaptado ao novo habitat humano, mais alto, esguio, enérgico e leve que os terráqueos, que se mostram pesados e desengonçados na gravidade marciana (o peso é talvez a única coisa imutável no planeta).

"O que é, então, o corpo do alien mais do que a expressão distorcida das possibilidades utópicas? E se sua alteridade fosse desconhecida porque ela significa uma alteridade radical latente

\footnotetext{
3 A science fiction se espalhou pelo mundo assim como o capitalismo, seguindo as mesmas diretrizes de colonização do futuro e a crença na tecnologia. "Exceto por alguns precursores insignificantes, a antecipação da ficção científica começou como parte integral da confiança que a Ilustração francesa tinha no progresso cognitivo e social”, afirma Darko Suvin em seu livro Metamorphoses of Science Fiction (1979).
}

4 A utopia acabou se refugiando ali, como Suvin aponta: "No século 20, a ficção científica passou ao campo do pensamento antropológico e cosmológico, torna-se um diagnóstico, uma advertência, um chamado à compreensão e à ação e -sendo este último o ponto mais importante - um mapa das opções possíveis” (p. 35, de Metamorphoses of Science Fiction) 
na história e na práxis humana, mais do que um não-eu de natureza física?”, pergunta-se Jameson no final do ensaio "The Unknowability Thesis" (Tese sobre a Impossibilidade de Conhecer) que antecede o texto específico sobre o tema "The Alien Body", presente em Archaeologics Of The Future (2005, p. 118).

Existe certo darwinismo na figura de Nirgal, uma mutação para o bem. O marciano nato tem poderes de um super-herói dos quadrinhos. Em Blue Mars, Nirgal aparece se dedicando à maratona tibetana, a arte de correr levitando e meditando (o lung-gom-pa), parte do folclore que envolve essa cultura. Além disso, Nirgal tem um poder curativo, emitindo calor, “derramando viriditas" em quem toca ou raios pelas pontas dos dedos, uma espécie de combustão metabólica, que aquece as pessoas e as sana. Por onde passa, as pessoas pedem sua ação milagrosa. Mas não é a nova raça humana que dá chave para a utopia. São os anciões terráqueos, os pioneiros em Marte, que lideram a mudança Nirgal tem como principal ação servir de elo com as corporações, afinal, parte dele a iniciativa de contatar a Práxis, sem o conhecimento ou o consentimento dos outros membros da resistência.

Em sua obra filosófica, que culmina com o livro O Princípio Esperança, Ernst Bloch (18851977) (2005) reinterpretou a utopia como “uma invasão dos limites dados ao homem” e, portanto, como uma qualidade inerente a todo pensamento e a todo ato criador. Na linha elogiosa, o sociólogo Karl Mannheim (1893-1947), cuja principal obra é Ideologia e Utopia (1929), classificou a utopia como qualquer orientação que transcenda a realidade e rompa os nexos da ordem existente.

Já o filósofo francês Raymond Ruyer (1902-1987) em seu livro L’Utopie et les utopies, sentencia: “A utopia é um jogo, mas um jogo sério. O autor de utopias capta as outras possibilidades da natureza, mas sem abandonar a noção de natureza.”. Para Ruyer, a matéria-prima da utopia seriam as “possibilidades laterais” (1961).

Por sua vez, Suvin contra-argumenta os críticos e afirma que “a Utopia não é nem profecia nem escapismo, e sim, como fizeram ver muitos críticos, um 'e se', um experimento da imaginação.” (1984, p. 81)

Até mesmo Oscar Wilde, apesar de apontar que há algo de desocupado e frívolo em construir outros mundos, escreveu que "um mapa-múndi que não inclua a Utopia não é digno de consulta, pois deixa de fora as terras a que a humanidade está sempre apontando" (frase do ensaio "The Soul of Man Under Socialism”, de 1891).

Entre os detratores, o pensador francês antimarxista Georges Sorel (1847-1922) viu nas utopias um "retrato retocado" da sórdida sociedade de sua época. Proudhon via os utópicos como personagens retrógrados de diferentes graduações, que criavam uma nova configuração com algumas melhoras, mas tudo acabava em uma "perspectiva açucarada" de paz social - muito longe da negação radical do presente, como queriam os anarquistas.

Como já foi dito, Marx atacou os socialistas utópicos para receitar o seu comunismo científico. E uma carta que ele escreveu em 1869 para o positivista inglês Edward Spencer mostra claramente seu pensamento: “Quem formula um programa para o porvir é um reacionário.”

Marx usou o termo “utópico” para desacreditar seus opositores teóricos e, com isso, a idéia de utopia também decaiu na esquerda. Afinal de contas, na direita, desde sempre, o conceito que denota uma mudança com o presente ganhou conotações pejorativas.

Como aponta o livro El Pensamiento Utópico en el Mundo Occidental (1984), posteriormente 
Marx e Engels requalificaram os sistemas utópicos como subprodutos de seu tempo e do caráter de seus autores, ou seja, Saint-Simon, Fourier e Owen se fascinaram com as possibilidades que a Revolução Industrial e a Revolução Francesa abriram e criaram mundos a partir delas, assim como hoje se criam utopias partindo do avanço digital e das conquistas políticas pontuais.

Marx era contrário às utopias como da mudança imediata, pregada por François Babeuf (1760-1797), considerado o primeiro comunista, por pregar a total igualdade durante os anos convulsionados da Revolução Francesa. Marx formulou uma mudança gradual, com estágios como a famosa "ditadura do proletariado". O pensador alemão não acreditava nem em uma igualdade imediata nem uma utopia longínqua, mas em períodos de transição.

Há tantas subdivisões utópicas quanto subgrupos na esquerda. Há os que crêem em uma sociedade totalmente igualitária ou outra com classes. Há utopias industriais e tecnológicas ou regressivas com tons campestres, quase parnasianos. Há aquelas com fervor revolucionário e derramamento de sangue e outras apaixonadas pelas urnas (as eletrônicas escancaram a lógica do movimento inexorável em direção da mudança devido aos avanços técnicos).

Nesse aspecto, a trilogia marciana de Robinson faz suas escolhas, apesar de preconizar a multiplicidade de utopias. Por exemplo, advoga a mudança gradual, prestigia as decisões por consenso, mantém classes e, apesar da preocupação ecológica, é simpática às sociedades tecnológicas, afinal, várias engenhocas e dispositivos são os responsáveis pela mudança climática e atmosférica do planeta.

Robinson faz uma opção pelo institucional. Esse é o porquê principal do capitulo constitucional em “A New Constitution”, terceiro capítulo de Blue Mars, com comitês, painéis, comissões, votações, reivindicações para formar a nova sociedade marciana.

Apesar da vertente de "teoria aplicada", uma utopia é essencialmente um texto ficcional, mesmo quando o tom discursivo faça o texto parecer um tratado e os aspectos literários ou plásticos ficarem em segundo ou terceiro plano. Ela descreve um Estado ou comunidade determinada e tem como tema a estrutura política desses lugares imaginários. Por isso mesmo, lá está o capítulo constitucional na trilogia.

Hoje em dia, entretanto, a utopia teria se alojado nas prateleiras de literatura no setor de ficção científica, espremido pela popularidade da fantasia. O crítico croata Darko Suvin (1984), que foi professor na universidade canandense McGill (Montreal), classificou isso: "Falando em um sentido estrito e com precisão, a utopia não é um gênero, mas sim o subgênero sociopolítico da ficção científica." $^{5}$

Esse especialista em ficção científica, nascido em Zagreb em 1930, apontou que o gênero é sempre crítico, mas a solução dada aos conflitos apresentados no enredo pode ser retrógrada ou conservadora. "Se tomamos os conceitos afins de ciência para cognição e ficção para estranhamento que o dicionário oferece, creio que há razões sólidas para chamar este novo gênero de ficção científica” (1984, p.36)

Suvin apresenta os conceitos de estranhamento e de novum (este último emprestado de Ernst Bloch) para diferenciar a science fiction das outras literaturas. "Como gênero literário, a FC se opõe

5 Isso ele escreveu na página 92 de Metamorphoses of Science Fiction, livro em que deu um panorama histórico e critico sobre o tema. 
ao estranhamento sobrenatural ou metafísico tanto quanto ao naturalismo ou ao empirismo", classifica o croata (idem, p. 30).

Ernst Bloch (2005) definiu da seguinte maneira a função real do estranhamento: "É - e deve ser - pôr um espelho revelador por cima de uma realidade demasiadamente familiar.” A ficção cientifica faz isso levando seus personagens para mundos distantes, futuros ou alternativos. Esse estranhamento está presente na trilogia marciana quando Robinson relata um planeta Marte de mudanças políticas - o mesmo não se pode dizer da conclusão do enredo, em que a sensação de déjà vu é maior.

O novum pode ser qualquer engenhoca, técnica, fenômeno, localidade espaço-temporal ou personagem que venha a introduzir algo novo ou desconhecido no ambiente empírico, tanto do autor quanto do leitor implícito. Em outros termos, ele cria uma descontinuidade que faz o leitor pensar: "esse não é o universo que eu conheço". Contudo, esse novum, segundo Suvin, é validado por um método científico ou uma lógica científica.

Suvin utiliza o termo novum como a inovação cognitiva, "um fenômeno ou uma relação totalizadora que se desvia da norma da realidade do autor e do leitor implícito”. Para ele, sua novidade é totalizadora no sentido que significa uma mudança de todo o universo do relato. "O novum é uma categoria mediadora, cuja capacidade de explicação brota de seu dom peculiar para estender uma ponte entre o literário e o extraliterário, entre o fictício e o empírico, entre o formal e o ideológico: em poucas palavras, de sua historicidade inalienável”, descreve. Suvin (1984) reafirma que o novum pode nos ajudar a compreender por que razões a ficção científica é um gênero histórico.

Tão histórico que tem seus períodos de altas e também de baixas, como está vivendo agora. Apesar de variada produção de filmes (é só lembrar a produção recente de Steven Spielberg, com Minority Report, Guerra dos Mundos e Inteligência Artificial) e livros (a obra de Robinson é um exemplo), o gênero foi superado em popularidade nas bilheterias e nas prateleiras pela fantasia de adolescentes magos, lugares quiméricos, heróis encantados, aventuras impossíveis e anéis mágicos, uma temática que lembra inquietantemente as preferências medievais.

As livrarias têm o costume comercial de juntar os livros de fantasy e science fiction em uma mesma área, considerando-os gêneros limítrofes entre si e muito distintos da literatura séria, tida "realista”. O crítico Robert M. Philmus define bem uma distinção entre os três: "a narrativa naturalista não requer explicação científica, a fantasia não a permite, e a FC a requer e a permite”.

Suvin até compreende porque fantasia e ficção científica são tão associadas. “A ficção científica comparte com o mito, a fantasia, o conto de fadas e as pastorais uma oposição com os gêneros literários naturalistas ou empíricos, se diferencia muito notavelmente de tais gêneros nãonaturalistas ou meta-empíricos por seu enfoque e sua função social” (1984, p.26).

O florescimento e a decadência do pensamento utópico escancaram a relação do gênero com a história. Por isso, as distopias são mais comuns em períodos pós-guerra. Aí está parte da explicação porque a ficção científica viveu um boom com a volta das utopias nos anos 60 da revolta política, da liberação sexual, química e de costumes. Isso talvez mostre a razão da science fiction produzir atualmente tão poucas utopias (o pot-pourri delas no planeta Marte de Robinson é uma das raras tentativas) em período em que não se vislumbram rumos alternativos. 


\section{II . ANÁLISE DA TRILOGIA MARCIANA}

Após uma visão geral da trilogia marciana, das idéias, da carreira de Kim Stanley Robinson e da riqueza interpretativa de que ela faz parte no último livro do ensaísta Fredric Jameson, cabe agora uma análise mais pormenorizada da narrativa e seus elementos de formação, começando pelas personagens.

Logo no início, o leitor sabe que terá por baixo uma centena de personagens para lidar ao longo das quase duas mil páginas épicas. Os First Hundred - Os Cem Primeiros formam o primeiro grupo de colonizadores do planeta e representam um coletivo de personagens (reverenciadas por uns, combatidas por outros, unidas em um determinado momento, dispersas na maioria do tempo), que, por sua vez, têm papéis e pesos bem diferentes ao longo do enredo. Uns são apenas citados, outros nem isso. Mas um grupo seleto acaba virando o guia no caminho em direção à mudança radical que o astro vermelho sofre até a terceira e última revolução em 2212.

Do subgrupo de 20 pioneiros que participam da história ativamente, a metade vai e vem na trilogia e poderia ser classificada como coadjuvantes. A outra metade seriam os protagonistas (Nadia Cherneshevsky, Maya Toitovna, Ann Clayborne, Sax Russel, John Boone, Frank Chalmers, Michel Duval, Arkadi Bogdanov, Hiroko Ai e Phyllis Boyle), mas mesmo entre eles apenas cinco atravessam os três volumes, com direito ao foco narrativo através deles e de realizar a proeza literária, graças ao tratamento geriátrico, de igualar o tempo subjetivo, o tempo histórico e o tempo geológico, testemunhando as transformações nos séculos 21, 22 e 23.

São eles Nadia, Maya, Ann, Sax e Michel. Apesar de serem tipos, personagens por excelência da forma épica, eles ganham o que poderia ser chamado aprofundamento psicólogo, pois, com o narrador, o tempo e as páginas ao lado deles, são expostos seus pensamentos, seus conflitos internos, seus sonhos noturnos, suas intimidades sexuais e suas mudanças ao longo do enredo.

Eles, contudo, são essencialmente personificações de pontos de vista científicos e/ou políticos que conversam o tempo todo e formam o longo diálogo de idéias na paisagem marciana que é esta trilogia, pontuada lá e cá com revoluções, ataques, contra-ataques, fenômenos climáticos e outras ações, gerando novos tópicos para mais debates.

"Não é uma contradição dizer que eu gosto de romance com personagens, mas eu gosto que minhas personagens tenham muitas idéias e que vivam em um mundo de idéias - como nós fazemos agora, então isso não é tão irreal”, declarou Robinson em entrevista à revista The Zone (LAWIE, 2002), sobre o porquê de suas criações encarnarem tanto uma plataforma, um ideário. Na própria narrativa é dito que os telespectadores da Terra "já estão começando a empregar o nome deles como uma espécie de código taquigráfico, uma sigla para as diferentes posições” (1993, p. 168), tal é a obsessão e a monomania de suas personagens, verdadeiros conceitos encarnados. 


\subsection{Sinopse da obra}

O primeiro volume, Red Mars (1993), começa com a cena do assassinato de John Boone, o primeiro homem a pisar na superfície marciana e líder carismático no início do processo de povoamento do astro vizinho. Com o herói pioneiro revelado morto já nas páginas iniciais, a narrativa retrocede então ao processo de seleção na Antártica para escolher os 100 cientistas e engenheiros para a empreitada capitaneada por EUA e Rússia: a lista é composta por 35 norteamericanos, 35 russos e mais 30 de outras nacionalidades, 15 escolhidos para cada lado (uma contabilidade que parece saída da lógica da Guerra Fria).

Já na viagem interplanetária dentro do transportador Ares, em 2026, começam as discussões políticas e científicas. O russo Arkadi Bogdanov advoga que eles devem fundar uma nova sociedade, sofrendo a oposição dos líderes dos contingentes norte-americano (Frank Chalmers) e também do russo (Maya Toitovna). Começa aí o confronto entre “o partido da Utopia” e o "partido da Terra", ou seja, entre os que querem reinventar e os conservadores que querem seguir as regras de Washington, Moscou e da UNOMA (sigla para United Nations Organization Mars Authority, fictício departamento da ONU responsável pela administração de Marte) - claro que, ao longo do extenso romance, várias personagens como a própria Maya e John mudam de lado.

Por outro lado, acontece o primeiro de uma série de debates entre o "terraformador" Sax Russel e a "conservacionista” Ann Clayborne sobre o papel da ciência em Marte: se transformá-lo em um ambiente próximo ao da Terra ou preservá-lo e estudá-lo em suas características originais. Além disso, já na nave é visto pela primeira vez o Coyote, o clandestino introduzido na nave por Hiroko Ai, a cientista japonesa responsável pelas plantações na espaçonave e na futura colônia.

Após a aterrissagem, são descritos os primeiros anos no novo lugar, com todas as inclemências do ambiente inóspito e o trabalho dos pioneiros para construir cidades, fazendas e fábricas embaixo de tendas com temperatura, pressão e ar controlados. O primeiro local de habitação, porém, é a Colina Subterrânea, onde os pioneiros compartilham um clima de cooperação para poder cumprir as milhares de tarefas. Parte da tripulação, liderada pelo "subversivo" Bogdanov, pára na lua Fobos para construir no satélite natural uma estação. Enquanto isso, Hiroko e o grupo que mantinha a granja somem e não estabelecem mais contato com os restantes. Nesse meio tempo, Marte recebe outras levas de imigrantes, como japoneses, suíços e árabes, que fundam cidades e fazem explorações econômicas - essas formam as colônias com presença importante na trama, mas outras também são registradas como chineses, gregos, afrikaners e etíopes.

Entre os fatos relevantes desse momento está o triângulo amoroso da líder Maya, que troca de parceiro segundo sua conveniência política, revezando nas mãos dos norte-americanos John Boone e Frank Chalmers - este último o representante do governo dos EUA no deserto astro. No decorrer do romance, John é alvo de uma série de atentados e começa por conta própria uma investigação particular para descobrir a razão. No transcurso, é perseguido por forças policiais enviadas pela Terra, preocupada com a nascente resistência que provoca sabotagens, fato que mostra 0 crescimento da ingerência das corporações capitalistas da Terra. Por outro lado, John aumenta sua popularidade com discursos defendendo uma independência marciana do planeta-mãe, incluindo sua participação no primeiro congresso entre os colonos, feito na elevação batizada de Monte Olimpo após o fim da grande tempestade que se alastra no início do enredo.

Mas John não vive o suficiente para participar nem da primeira de três revoluções no planeta (uma para cada volume da trilogia). Seu assassinato tem por trás a comunidade árabe em Marte, 
irritada com o norte-americano principalmente depois de seu conterrâneo Frank tê-los insuflado contra uma suposta posição antiárabe de John.

A expansão das corporações terráqueas inclui a construção de um elevador espacial, entre a lua Fobos e o planeta, para aumentar o fluxo de pessoas e de negócios por lá, mas também traz um cenário caótico com campos de refugiados, o surgimento de gangues, a atuação de máfias russas, o aparecimento de epidemias de tuberculose, a multiplicação das greves, um estado policial reprimindo as manifestações e a total falta de infra-estrutura para receber uma migração em massa. Marte chega nesse momento a uma população de um milhão de habitantes, muitos deles desaparecendo, atraídos pelos refúgios escondidos onde vivem os grupos contrários à dominação capitalista do planeta. Um novo acordo para limitar migração e exploração mineral é assinado, mas a própria UNOMA desobedece as regras.

Reagindo a essa situação distópica (simultânea a um cenário de guerra mundial na Terra, rápida e um combate de todos contra todos, sem alianças ou eixos como nas Guerras Mundiais do século 20), a insurreição é detonada em 2061, com mais de 60 cidades-tendas se declarando independentes da Terra, muitas tomadas pelos bogdanonistas. A principal delas é Nicosia, mesmo cenário do assassinato de John. Outra vez, essa cidade é trágica para os independentistas: Bogdanov e parte de seu grupo acabam na maioria mortos no bombardeamento por parte da UNOMA, que detém a última palavra nos temas, mas cada vez mais é influenciada pela pressão das metanacionais e interesses das grandes nações. A guerra inclui a derrubada de Fobos, minada por Bogdanov em sua passagem por lá, e, consequentemente, o elevador que a ligava ao planeta se espatifa no solo marciano.

Após a fracassada tentativa, os sobreviventes dos "Primeiros Cem” (entre os 21 mortos estão Alex, Sasha, Edvard, Samantha e Yeli) empreendem uma retirada para os esconderijos. Na fuga, Frank acaba morrendo engolido por uma avalanche quando tentava desatravancar o veículo que os transportava. "Red Mars" termina com a entrada desse grupo de fugitivos no refúgio de Hiroko no pólo Sul, onde impera a areofania, espécie de religião que celebra Marte e cuja líder é a cientista japonesa. Ao final do volume, todas as lideranças masculinas estão mortas: John Boone, Frank Chalmers e Arkadi Bogdanov. O planeta, mineral no começo, já sente a transformação e as últimas cenas são dignas de um "Marte Branco", com neve cobrindo a paisagem e um esconderijo no meio do gelo polar como albergue. O tom é de frustração e tristeza, mas o novo lar deixa no ar um fio de esperança. A última frase dita por Hiroko deixa claro isso, como num folhetim, num filme que terá sua seqüência ou uma novela de TV: “Aqui será onde nós começaremos de novo.”

Já Green Mars (1994) inicia-se com a história de Nirgal, garoto incubado em uma piscina, como uma série de outros descendentes de Hiroko e do banco de espermatozóides abastecido por alguns dos exemplares masculinos entre os primeiros colonizadores. Os primeiros marcianos natos são denominados “ectógenos", todos com traços asiáticos, elevada altura e menor densidade óssea (semelhante aos pássaros), causada pela gravidade menor - a maioria deles canhotos, supostamente porque eles sofreram algum tipo de manipulação genética.

É o ano de 2091 (30 anos após a revolução fracassada), e o refúgio da resistência chamado Zigoto, cavado na calota polar meridional, hospeda a primeira geração marciana sob a tutela dos professores pioneiros Sax Russel, Maya Toitovna, Nadia Cherneshevsky, Frank Duval, Hiroko Ai, Ann Clayborne e Simon Frazier (o total de habitantes permanentes é de 124, mas flutua até 200, dependendo das visitas de pessoas de outros refúgios da resistência, que somam um contingente de cerca de 5.000 pessoas). 
O capítulo de abertura acompanha Nirgal em sua descoberta da morte, do sexo e de suas origens. Ele presencia a morte quando não consegue ajudar com seus poderes de cura a Simon Frazier, companheiro de Ann. Também é o momento da experiência sexual, principalmente com Jackie, que é neta de John. Em seguida, ele tem de encarar a revelação que Coyote é seu pai. Os dois se aproximam quando o penetra convida o garoto para participar de suas incursões pela superfície marciana e sair daquela redoma de gelo, daquele universo indoor.

No capítulo seguinte, a ação tem um corte abrupto e se desloca para a Terra, onde o pequeno empresário recém-divorciado Arthur Randolph, ou Art, é arregimentado pela metanacional Práxis para estabelecer relações com a resistência de Marte, que tenta fazer contato com essa corporação terráquea - ela é apresentada como uma versão mais conseqüente, consciente e com procedimentos diferentes de suas predadoras concorrentes. Ele passa por um treinamento em um utópico litoral onde vivem os capitães da empresa, incluindo seu fundador, William Fort. Art é escolhido, viaja ao planeta e, com a ajuda de Nirgal, que teve a idéia de sondar a mega-empresa, ele se infiltra na resistência.

Enquanto a superfície de Marte vai aos poucos ganhando formas iniciais de vida e uma atmosfera mais próxima da Terra, a partir dos mais diversos métodos (moinhos de ventos com algas azuis, lentes e espelhos em órbita para aumentar a insolação, reatores nucleares, buraco de transição entre superfície e o manto de até 18 quilômetros de profundidade), continua a idéia de tomar o controle político do astro que está nas mãos das transnacionais com nomes como Subarashii, Amex, Armscor, Shellalco e Oroco. O centro das decisões, que antes da revolta de 2061 estava com a ONU e seu departamento marciano UNOMA, passa para um órgão cuja sigla é UNTA (Autoridade Transitória das Nações Unidas), que, na verdade, é um grupo dominado por executivos das transnacionais e que de transitória não tem nada, está mais para a idéia de Estado de exceção permanente, o temporário perene.

Estereótipo do cientista, Sax Russell se cansa da vida pacata de professor em Zigoto e decide entrar com identidade falsa e rosto cirurgicamente modificado na cidade de Burroughs, capital de Marte corporativo. Dessa maneira, volta a sua obsessão: a terraformação. Lá, acaba se envolvendo com Phyllis Boyle, a integrante dos "Primeiros 100" que se muda de vez para o lado dos interesses capitalistas. No meio do affair, ela reconhece sua verdadeira identidade, e ele acaba detido e torturado pelas forças policiais. Seus companheiros preparam o resgate do prisioneiro, com a ajuda do agente infiltrado Spencer Jackson. Na ação, Maya mata Phyllis e é recriminada pela violência. Na fuga, o grupo se divide, e uma parte tenta recuperar Sax estropiado após tantas sessões de tortura enquanto esteve detido. Ele vai aos poucos se restabelecendo, mas levando com ele sequelas que irão mudar seu temperamento e sua fé na ciência como único motor das coisas.

É nesse momento, em que a resistência se mostra para o status quo esperando uma reação após o resgate ousado, que o infiltrado Art propõe uma reunião para tentar um acordo mínimo entre os vários grupos da resistência (Marte primeiro, Marte Livre, os vermelhos, os verdes, os bogdanovistas, os seguidores da areofania, entre outros).

O congresso da resistência acontece em uma gigantesca caverna em Dorsa Brevia, em vários dias de discussões dos mais variados temas, desde a economia e a questão árabe até chegar nos limites de mudança na superfície e na atmosfera de Marte.

Duas “aparições” se destacam nesse encontro. A primeira é a de William Fort, fundador da Práxis e para alguns um inimigo da causa. Ele explica suas intenções ao querer se associar com a resistência e faz um relato do que está acontecendo na Terra, inclusive explicando o termo 
“metanacional”, que seria uma versão expandida das transnacionais (algo maior que as atuais multinacionais), que passaram a gerir e incorporar países, além de rivalizar com interesses de outras nações e megaempresas concorrentes. A outra aparição é a de Hiroko. Ela desponta quando a reunião parecia se encaminhar para um final chocho e realiza um ritual de areofania para celebrar a criação do documento.

Selado o compromisso de Dorsa Brevia, que para muitos ficaria só no papel, é hora da narrativa se deslocar para o novo Sax, após o cérebro sofrer um tratamento plástico. Com a ajuda de Peter Clayborne, filho de sua oponente Ann, ele começa uma onda de sabotagens, derrubando a lente que aquecia a superfície e gerava uma inundação de gás carbônico na atmosfera. Ele também faz o satélite Deimos, potencial base de ataque das metanacionais, sair de órbita. Essas ações extremas geram um contra-ataque das forças oficiais, com a tomada de cidades do chamado demimonde (locais como a cidade de origem japonesa Sabishii, que, tendo até universidade, vive à margem da lógica metanacional e abriga alguns opositores) e de refúgios da resistência (o que força novo sumiço de Hiroko e seus seguidores).

Os vários grupos da resistência planejam uma nova revolta, cada um por si só. Mas graças à coordenação de alguns dos pioneiros da colonização, esperam um fato desencadeante que possibilite uma mobilização bem-sucedida. E ele acontece: em meio a uma guerra entre metanacionais na Terra, o planeta originário da humanidade se vê inundado pelo brusco derretimento polar da Antártida, com a subida de seis metros de todos os oceanos, causando a submersão de todo o litoral mundial, consequentemente, de milhares de cidades. A situação calamitosa na Terra é o estopim para a resistência marciana tomar o planeta. O segundo volume termina com a capital corporativa Burroughs inundada após a explosão de um dique próximo que continha água e gelo. A população abandona o local guiada pelos líderes e vislumbram um futuro diferente para Marte com a saída das gigantescas empresas e sua ganância da face do planeta.

Blue Mars (1996) marca a transformação total de Marte. O volume termina com cruzeiros marítimos nos oceanos de lá e a derradeira cena acontece em uma praia paradisíaca. É o livro da trilogia mais fragmentado, mais acelerado, com mais capítulos (quase o dobro de Red Mars) e mudanças de personagens e de ambientes focados - inclui até uma visita à Terra de uma delegação do astro vizinho.

Dessa vez, vencida a batalha pela independência, os grupos verdes e vermelhos (respectivamente, os favoráveis e os opositores da terraformação) estão à beira de uma guerra civil, enquanto os representantes das metanacionais permanecem isolados na área em torno do elevador de saída do planeta.

Nesse cenário, Ann, maior defensora de um Marte primitivo e vermelho, exige para seu rival Sax, anteriormente obcecado pela terraformação, mas com as idéias reformadas após a tortura e subseqüente operação cerebral, que ele derrube a soleta instalada em órbita para aquecer e espessar a atmosfera. Sax cumpre a promessa em seu processo de aproximação com a adversária ideológica que no final da narrativa se tornará seu par romântico.

Na seqüência, a ação corta para a realização do congresso constitucional, para definir o futuro e apaziguar as diferenças, apesar do grupo vermelho ficar de fora e continuar com sua estratégia de sabotagens. Entre as decisões está a criação de uma federação, com o poder descentralizado e cada cidade-estado definindo como será a vida por lá. Fica instituída a criação de um parlamento bicameral para reger o planeta, com um Senado e uma Duma, que escolheriam o conselho executivo - a primeira presidente é exatamente Nadia, que coordenou a Constituinte, ao lado de seu par 
romântico Art.

É determinado que não haverá propriedade privada e que as empresas serão dos trabalhadores. Também se define que as áreas altas do planeta ficarão intactas para atender o desejo preservacionista dos vermelhos, com a criação de um tribunal para mediar os interesses dos grupos antagônicos.

Durante a Constituinte, parte para a Terra uma delegação marciana formada por Maya, Michel e Nirgal, que fica impressionado com o planeta de onde é originária a humanidade, principalmente com a chegada na tropical e picante Trinidad e Tobago, terra natal de seu pai, o Coyote. Enquanto Maya se concentra em fechar um acordo com os terráqueos na Suíça, Nirgal parte à procura de sua mãe, Hiroko, após receber várias pistas desencontradas de seu paradeiro. Por seu lado, o francês Michel retorna a sua terra natal, a Provença, para matar a saudade e insiste para Maya acompanhálo. Nirgal acaba se adoentando e voltando convalescente para Marte, se recupera e acaba se isolando primeiro em uma granja e depois fazendo uma peregrinação.

Em uma de suas andanças aparece diante de Zo, filha de Jackie, que Nirgal confunde com Diana, a deusa da caça para os gregos. Além de levar uma vida hedonista e arriscada (pratica uma espécie de vôo com roupas de pássaros e direito a quedas livres e rasantes), a garota atua politicamente em favor da mãe em todo o planeta solar, que na década de 2170 sofre uma expansão humana por Mercúrio, Júpiter e Saturno. Depois de seduzir Sax e brigar com Ann, Zo morre ao final do capítulo intitulado "Viriditas" em um acidente aéreo durante uma das sessões de seu perigoso hobby.

Sua morte afeta profundamente sua mãe, que está em campanha eleitoral para escolher o novo parlamento, enfrentando Maya. Enquanto Jackie adota uma posição de afastamento em relação à Terra e acena com uma restrição da migração dos terráqueos, Maya promete ser mais liberal quanto ao tema. Jackie acaba perdendo, se retirando da política e viajando para Aldebarã (sistema solar mais próximo do nosso), com direito a despedida no embarque de Nirgal, que não confessa sua paixão para o amor de toda vida.

A virada do século 22 para o 23 presencia também a morte de algumas figuras entre os "Primeiros Cem", como Michel, Vlad e Spencer. Além disso, os 14 sobreviventes entre os pioneiros sofrem com a falta de memória. Sax, com a ajuda da novata cientista Bao Shuyo, que aparece como sucessora sua nas invenções marcianas, desenvolve tratamento com substâncias e ondas eletromagnéticas que recuperam as reminiscências dos veteranos. Uma em especial dá desfecho a um dos mistérios da trilogia até ali: Ursula Kohl aplica o experimento em Zeyk, o chefe árabe, que retoma os fatos do dia da morte de John Boone e aponta que os responsáveis pelo assasinato foram Yussuf e Nejm, que eram da ala Fetah da comunidade islâmica. Outras personagens fazem o tratamento simultaneamente na Colina Subterrânea, o que garante um episódio com um flashback coletivo, com Sax, Ann, Coyote e Nadia vislumbrando tudo o que passou em suas vidas. Nesse momento, Sax confessa seu amor pela sempre antagônica Ann, e os dois partem em cruzeiro romântico.

A saga termina com a notícia da terceira revolução no planeta, detonada pela invasão de tropas terráqueas do elevador espacial de Marte. A reação é imediata, e a população vai às ruas para manifestar sua contrariedade com a ação unilateral. É uma espécie de revolução de veludo, com imagens similares às vistas a partir de 1989, quando a queda do Muro de Berlim detonou uma série de quedas dos regimes no Leste Europeu (com direito a beijos nos soldados e Carnaval na rua). Após esse episódio, um novo acordo é selado com a Terra que abranda a migração para Marte. 
A cena final da trilogia acontece em uma idílica praia quando a deprimida Ann (tenta três vezes o suicídio ao longo dos livros) sofre um mal súbito, mas contrariando sua pulsão de morte, ela luta para sobreviver e consegue, o que marca uma guinada em sua visão de mundo. 


\subsection{As personagens}

O narrador da trilogia troca de personagem focada de um capítulo para o outro. No total, 12 deles ganham essa escolta privilegiada - entre eles, alguns descendentes dos pioneiros (Nirgal, Zo e Peter Clayborne), além de um personagem que surge na trama pelo lado das corporações (Arthur Randolph).

Arkadi Bogdanov e Peter Clayborne (filho de Ann) têm direito, cada um, ao narrador na cola apenas em uma introdução de capítulo (texto curto em itálico que antecede e, por vezes, precede o corpo principal da parte, aumentando ainda mais a fragmentação da narrativa). A Peter é concedida atenção só em seu resgate, quando estava em queda livre após o elevador marciano ser destruído como conseqüência da explosão de Fobos (uma nave com duas mulheres realiza o milagre do salvamento nesse trecho de texto em forte tom onírico). Já Arkadi é focado para descrever sua própria morte na revolução de 2061.

Outras figuras-chaves do extenso enredo nem disso dispõem. Hiroko Ai, Jackie Boone, Phyllis Boyle e Desmond Hawkins (o Coyote), só para dar os exemplos mais emblemáticos, só aparecem na história quando o protagonista do trecho esbarra em algum eles. Devido a essa précondição, eles estão quase sempre em algum lugar desconhecido na maioria do tempo.

Quatro deles são especialmente perseguidos por quem conta a colonização marciana: Nadia, Ann, Sax e Nirgal, cada um ganhando o primeiro plano em cinco capítulos ao longo do enredo. Não por nada são eles que sofrem as maiores transformações diante dos olhos do leitor - seriam assim round characters, conceito que também poderia ser aplicado ao verdadeiramente arredondado planeta Marte e suas mudanças de cor.

O distanciamento da caracterização das personagens como apenas tipos também é uma valorização da mudança, fugindo do determinismo que o tipo impõe às figuras fictícias seja ao longo do tempo da narrativa (por isso o conceito de E.M. Forster de rotação das "personagens esféricas") seja ao longo do espaço físico (daí a idéia que Jameson utiliza de multiple subject position, em português "múltiplas posições do sujeito", com as personagens trocando sua subjetividade segundo o fragmento da sociedade em que estão em determinado momento).

Nirgal muda de líder carismático entre os marcianos natos para um ermitão. Nadia, de construtora apolítica, vira uma líder, a primeira presidente de Marte. Já Sax começa como cientista racional e frio (rotulado de "um rato de laboratório"), mas, após ser preso, torturado e sofrer uma operação cerebral, se torna o sabotador mais eficiente do planeta, para depois terminar como o parceiro romântico de sua eterna antagonista Ann, com direito à meiguice de criar uma lua para ela e, depois, se declarando em um "Eu te Amo", reeditando o clichê melodramático dos opostos que se atraem, o que, na esfera política, seria uma solução conciliadora, social-democrata. Com Ann não é diferente: de uma mórbida fixação com o mineral e com a morte (tenta, como vimos, três vezes o suicídio), ela termina lutando pela vida e sobrevivendo quando sofre um mal súbito no final da trilogia.

As brigas e os debates dentro do casal dialético Sax e Ann são uma constante na trilogia, e são vistos dos dois ângulos, como também de fora. Robinson revela em entrevista que esse é um traço de sua personalidade que ele estampa em sua obra, mas também é reveladora da subjetividade múltipla que Jameson aponta como característica nas utopias pós-modernas, complicando um pouco a dicotomia indivíduo-coletivo. 
"Eu fico muito feliz em me contradizer. Quando eu faço uma afirmação, muito rapidamente me ocorre justamente o contrário como sendo tão verdade quanto. Eu não sou um pastor ou um polemista por natureza porque eu não sou muito convicto no meu sentimento do que é verdade. Acho que isso é uma vantagem para um romancista. É como jogar dos dois lados de um tabuleiro de xadrez, enquanto estou de um lado eu posso perder de vista a tática que o outro lado pode tomar (...) Nos livros sobre Marte isso foi muito útil”, afirmou em entrevista. (LAWIE, 2002). A forma dialógica do autor indeciso está tanto no conteúdo como na forma da trilogia - prova disso é a troca de personagens focados de um capítulo para outro.

O conflito entre terraformar e preservar a geologia de Marte é o principal tema de atrito dentro da resistência e perpassa toda a trilogia, até a solução mediadora de limitar o processo segundo a altitude da região. Comentando especificamente esse assunto e essas personagenssímbolo, Robinson disse à revista eletrônica Sci-Fi Universe (BABCOCK, 1996): “[Ann e Sax são] eu lutando com meus próprios pensamentos sobre o assunto. É muito fácil para eu variar entre os pontos de vista de Ann e Sax, porque isso depende basicamente em quem estou focando naquele momento". E continua: "Trabalhando duro nesses livros, eu podia chegar a um estado onde era como anotar recados telefônicos ou ser um intermediário dessa função.”

Em seu ofício literário, Robinson reproduziria o modelo do homem de "múltiplas posições do sujeito", tão característico do pós-modernismo, como Jameson aponta no ensaio "Utopia And Its Antinomies” (“Utopia e Suas Antinomias”): “A obtenção de uma impersonalidade radical na utopia, o apagamento da propriedade privada do eu e a emergência de novas práticas descentralizadas e coletivas de relações individuais e sociais não corresponderia a uma abolição da subjetividade, mas uma nova forma da mesma, na qual o individualismo burguês - outro nome para o velho conceito humanista do 'homem centrado', sob ataque das teorias contemporâneas - foi substituído pelas 'múltiplas posições subjetivas' da pós-modernidade e do capitalismo tardio. Outra vez a noção de replicação do sistema vira a forma final de teoria da conspiração, e o conceito de uma transformação utópica se torna um recurso extra no depósito dos truques e atrações do capitalismo tardio” (2005, p. 168).

Essa postura é o foco da crítica de Slavoj Zizek, que ficou célebre no cenário intelectual ocidental juntando as teorias psicanalíticas de Jacques Lacan (1901-81) às idéias de Hegel (17701831). Segundo as palavras de Vladimir Safatle, no posfácio para o livro Bem-vindos ao Deserto do Real! (2003), o pensador esloveno denuncia “a crença na multiplicidade plástica das formas contemporâneas de subjetivação e na contingência radical daquilo que procura se colocar como póshistórico.” Jameson e Zizek basicamente colocam sinal positivo (o primeiro) ou negativo (o segundo) diante do questionamento do sujeito sendo o centro, processo que começa com a psicanálise e se estende para as chamadas ciências humanas. Jameson aposta nas possibilidades de diálogo, nos frutos do confronto e na síntese entre os fragmentos para fazer frente ao centro, oculto atrás de camadas supostamente tolerantes, diversificadas e democráticas. Já Zizek (2003) prefere ressaltar as interdições da pós-modernidade.

Há uma cena ilustrativa em Red Mars, em que o espelho, tão simbólico da divisão subjetiva para Lacan, cumpre um papel revelador. Na cidade de Stickney, na lua marciana Fobos, Arkadi discute com John sobre a situação política de Marte em uma grande galeria "que a primeira vista parecia demasiadamente grande para estar contida em Fobos: o piso, parede e o teto cobertos por espelhos facetados; umas placas redondas de magnésio polido estavam dispostas obliquamente, de modo que qualquer um que se encontrasse nesse espaço de microgravidade se via refletido em milhares de regressões infinitas.” Na chegada a essa sala, eles "aterrissaram e engancharam os pés em umas anilhas e flutuaram como plantas no fundo do mar em uma movediça multidão de Arkadis 
e Johns” e depois ao final da conversa por lá "um milhão de Arkadis se ramificaram em torno de John, com uma expressão muito mais grave que a de qualquer uma daquele Arkadi que ele pudesse lembrar - tão séria que as florescentes fileiras da própria cara de John exibiram uma expressão regressiva de preocupação boquiaberta” (1993, p. 340-344).

De tão leve, a passagem caleidoscópica reproduz a microgravidade local e, de tão elegante, se assemelha a uma teoria científica bem amarrada. Arkadi defende uma solução radical, a revolução, para tirar Marte das mãos terráqueas e corporativas. John quer um novo acordo. O espelhismo revela ao mesmo tempo a multiplicação e a fragmentação dos personagens, gerando a sensação que há um coletivo por trás dessas figuras, mas também revela uma individualidade desconhecida, como se ela não existisse ou fosse outra (o russo está mais sério do que costumava aparecer).

Ao mesmo tempo, o jogo de espelhos em diversos ângulos revela que a reprodução, a replicação, na verdade, é uma regressão - por isso, a insistência do termo nesta passagem. A ênfase é no efeito regressivo do reflexo do reflexo infinito (um atrás do outro como quando se coloca espelhos em paralelo), que deixa a imagem multiplicada cada vez mais indefinida e sem contraste. Daí é um passo para o "eu” decretar sua negação, sua cisão, seu deslocamento, sua dispersão ou qualquer outro "fenômeno"

Esse individualismo pós-moderno que se acredita múltiplo é alvo fácil para críticos como Zizek. Segundo Safatle (in ZIZEK, 1996), o pensador esloveno entra no debate da contemporaneidade pela politização desta "defesa da irredutibilidade do sujeito" e mobiliza isso na sua crítica contra a ideologia da "livre escolha" (conceito chave para a solução utópica de Robinson, com uma superfície marciana povoada de utopias surtidas). Isso é próprio do multiculturalismo liberal.

Nas palavras de Safatle, essa ideologia terá como ápice “o uso da noção de gender como construção performativa do sexual”, mas que "o desejo não se satisfaz na assunção de identidades ligadas a particularismos sexuais". Escreve o autor brasileiro: “O sujeito é aquilo que nunca é totalmente idêntico a seus papéis e identificações sociais, já que seu desejo insiste enquanto expressão da inadequação radical entre o sexual e as representações do gozo (seja na forma de identidades como queer, lésbica, sadomasoquista, andrógenos, etc.)”.

Aliás, o paradoxo é que tanta liberdade sexual só serve apenas para as pessoas se rotularem em um target. Contudo, a trilogia de Robinson não dá uma solução federalista para o sexo. A liberalidade dos primeiros anos de colonização logo é substituída por uma estrutura mais familiar, como se passasse da solteirice da juventude para a vida matrimonial e responsável da maturidade. Somente há indicações que algumas cidades apontam para um hedonismo também típico de nosso tempo pós-moderno em que se ordena que as pessoas consumam, desfrutem e muito nesse "nicho".

O exemplo sexual, mobilizado por Zizek (1996) e citado por Safatle, serve para denunciar a tal tolerância da multiplicidade liberal, afinal, "a falsa universalidade do capital acomoda-se muito bem a esta multiplicidade”.

“Todas estas reivindicações identitárias (que se dão principalmente na esfera do mercado: para cada público-alvo, uma linha completa de produtos e uma linguagem publicitária específica), estão subordinadas à falsa universalidade do capital. O mercado é o único meio neutro no qual tal multiplicidade pode articular-se assumindo a figura de uma rede mercantil de targets. Para Zizek, toda política de identidade faz assim necessariamente o jogo do capital”, escreve Safatle no mesmo posfácio. No limite, o multiculturalismo corrobora a tese do fim da História, afinal, em sua lógica 
descarta a política e aponta que todo o conflito é cultural.

Em Postmodernism or The Cultural Logic of Late Capitalism (1991), Jameson define o elemento constitutivo do pós-modernismo e seus efeitos: a nova superficialidade (new dephtlessness) e o conseqüente esmaecimento da historicidade e também do afeto. Não há mais a profundidade e a preocupação com a memória que as artes do alto modernismo tinham. No lugar delas, entra a superfície múltipla. "Se o capitalismo sempre buscou esconder o tanto de exploração e iniquidade necessárias para manutenção do mundo sob a égide da forma mercadoria, a ofuscação só se acentua na nossa era dita pós-industrial, que encobre a luta de classe sob a saturação de mídia, e a fragmentação do sujeito sob os prazeres serializados do consumo”, escreve Cevasco sobre a análise de Jameson sobre a função da cultura atual na sociedade (2008).

O próprio teórico admite que várias das características do pós-modernismo já estavam presentes no movimento moderno - ele comenta que o dadaísta Marcel Duchamp e o surrealista René Magritte poderiam ser considerados precursores da guinada seguinte da cultura. Para Jameson, em algum momento entre os anos 50 e 60 do último século, houve uma mudança na cultura, com uma grande quantidade de obras que mostravam a tal "crise do subjetivismo". Tamanho foi o número dessas produções que, na verdade, houve uma mudança de qualidade em relação à arte do movimento anterior. Enquanto nessa época o modernismo era aceito pelo Establishment (exemplo clássico são quadros de Pablo Picasso decorando sedes de banco), o pós-modernismo já nasceu dentro da lógica do consumo, utilizando elementos da cultura de massa.

Para o crítico, o desaparecimento do afeto resulta na transformação dos objetos em meras mercadorias, em um mundo em que até a natureza e o subconsciente estão colonizados pelo lucro. Esse império da superfície, revelador da contemporaneidade, relegou a profundidade e seus modelos teóricos - como o dialético (aparência e essência), o freudiano (manifesto e latente), o existencial (autenticidade e inautenticidade) e até o tardio semiótico (significado e significante).

Como efeitos dessa fragmentação, temos o fim do estilo particular e o reinado das colagens e pastiches, que não são mais citações, mas são "incorporadas na própria substância” da arte pósmoderna. A História, com H maiúsculo, vira um simulacro, só interessando a coleção de imagens (uma nostalgia das características brilhosas do passado) e não a recuperação de sua lógica dinâmica da transformação.

Literariamente, isso acaba na, usando as palavras do próprio Jameson, “canibalização de todos os estilos do passado" e a hegemonia de tudo o que é “neo”, em referência a uma idéia de Henri Lefevre. Ou seja, o pós-modernismo substituiu qualquer tipo de relação diacrônica em sincrônica a proposta de federalismo utópico mostra, porém, sugere uma solução na espacialização do que antes era temporal, ou seja, a História. Jameson elabora a idéia em sua introdução ao livro "PósModernismo - a Lógica Cultural do Capitalismo Tardio”, na página 19, da edição brasileira, tradução de Maria Elisa Cevasco: “A Utopia é uma questão espacial e poder-se-ia pensar que sua sorte teria potencialmente condições de mudança em uma cultura tão espacializada quanto o é a cultura pós-moderna, mas, se esta é tão desistoricizada e desistoricizante, como às vezes afirmo aqui, fica mais difícil localizar a cadeia sináptica que poderia levar o impulso utópico à sua expressão. As representações utópicas tiveram um extraordinário revival nos anos 60; e se o pósmoderno é o substituto para os anos 60, e a compensação por seu fracasso político, a questão da Utopia deveria ser o teste crucial do que restou de nossa capacidade de imaginar qualquer tipo de mudança.” 
Como doutor em literatura, Robinson usa vários dos dispositivos da nova escola em sua ficção científica. Além de refletirem o conflito interno no ideário de Robinson, é curioso ver também que algumas personagens reproduzem o trabalho do escritor de pesquisar os assuntos antes de escrever seus livros - ele contraria a receita "escreva sobre o que você conhece” e adotou o lema "pesquise o que vai escrever".

É assim com Sax após o trauma da prisão e tortura, quando procura estudar as chamadas “ciências humanas” para entender porque seu ponto de vista científico é tão criticado como limitado e reducionista pelas outras personagens. O mesmo ocorre com Maya em sua pesquisa atrás da verdade entorno da morte de John Boone e da suposta participação de Frank Chalmers.

Mas ninguém prefigura mais esse escritor-pesquisador que Michel Duval, o psicólogo entre os pioneiros. Logo no quarto capítulo de Red Mars, ele aparece em breve relato (todos em que o narrador o persegue são curtos). Nesse trecho, Michel estrutura a distribuição dos primeiros habitantes de Marte pelos humores, uma referência a antiguíssima divisão de Hipócrates (460-370 a.C) dos temperamentos entre melancólicos, fleumáticos, coléricos e sanguíneos.

Segundo a teoria humoral hipocrática, que dominou a medicina do século IV a.C até o século XVII, a vida era mantida pelo equilíbrio de quatro fluídos: sangue, fleuma, bile amarela e bile negra. O sangue viria do coração e determinaria um caráter otimista, confiante, popular e energético para as pessoas sanguíneas. Já o excesso de bile negra, que seria secretada pelo baço, faria os homens ficarem melancólicos. Por seu lado, os coléricos teriam muita bile amarela, produzida pelo fígado. E por último, a fleuma seria produzida pelo cérebro (por isso, o caráter racional) ou os pulmões (daí o aspecto aéreo de calma dos fleumáticos).

Esse jogo de humores também foi levado em conta por Fourier na montagem de seu falanstério, cidade-edifício utópica. O francês acreditava ter estendido a física de Isaac Newton e sua teoria das atrações para a área da sociedade. A formação de grupos teria, portanto, que obedecer à mistura de temperamentos. E Fourier catalogou mais de oito centenas de combinações possíveis de caráter dentro do falanstério. Para ele, as paixões humanas são divididas como os 12 signos do zodíaco, e distribuídas em quatro ramas principais, incluindo a paixão pelo luxo, pela intriga e até pela variedade - esta última, muito em moda nesses dias de diversidade multiuso. Essa lógica está presente hoje em dia na crença popular que a (utópica) felicidade matrimonial está no arranjo de índoles baseada no horóscopo. Cada homem seria um composto dessas 12 paixões. E, caso de problema mais sério, estava previsto nos falanstérios que em certas ocasiões houvesse a intervenção de experts em psicologia, como Michel Duval atua na trilogia marciana. Enquanto Saint-Simon fez uma divisão mais sociológica (com tipos sociais fixos) e Owen defendeu um comunismo de tipo monástico, Fourier se baseou em uma lógica psicológica para criar sua utopia.

Por um lado, ele previu algumas relações livres e outras fixas, sem que haja monogamia (algo sugerido no começo da trilogia marciana). Outra similaridade com Robinson é que Fourier atenuou o papel do dinheiro e da família. Nos falanstérios, haveria ricos e pobres, mas os prazeres seriam tantos e tão espraiados que o dinheiro deixaria de ser o facilitador do acesso a eles (mas o utópico admitiu diversos graus de prazer segundo o refinamento).

Além do dinheiro, o papel da família também termina esmaecido. O elo pelo parentesco não é suprimido, mas há outras formas de contrato amoroso que a tal instituição (os adolescentes e jovens criam diversas formas de relacionamento para acabar com a hipocrisia monogâmica). Em diversos momentos da trilogia, principalmente na criação da primeira geração marciana no refúgio polar, a 
família perde espaço para uma formação mais social. Além disso, há relatos de relacionamentos ruins entre Nirgal e sua genitora, Hiroko; e, da mesma forma, entre Peter e Ann, que repete a frase "não me venha com essa história de mãe".

Mas no fecho de Blue Mars, com a derradeira cena na praia, prenunciando um eterno domingo para a humanidade, a família ressurge como um elemento atemporal. Segundo Jameson, a família pode ser classificada como esse "pequeno grupo cuja existência não pode ser banida da Utopia ou esquecida e expelida com sucesso”, baseando sua persistência em um fundo biológico.

Além da psicologia, do dinheiro e da família, outro tema de fundo aproxima Robinson e Fourier. O pensador francês aponta que a liberdade só acontece quando há uma multiplicidade (uma idéia muito entranhada na mentalidade atual). "A psicologia de Fourier se baseia na premissa que a salvação e a felicidade se radicam na pluralidade e complexidade: a verdadeira liberdade se desenvolve sempre em meio à multiplicidade”, interpretam a dupla Frank e Fritzie Manuel, em seu El Pensamiento Utópico en el Mundo Occidental (1984).

No relato de Robinson, entretanto, para esquematizar a disposição, ele utiliza os retângulos semânticos criados por Algirdas Greimas (1917-1992), lingüista lituano que bolou esses desenhos porque acreditava que somente a dialética não dava conta da complexidade dos grupos de conceitos relacionados. Robinson pega emprestado esse instrumento das páginas em que seu ex-professor Jameson lança mão desse dispositivo estruturalista que utiliza em vários textos analíticos. Antes de apresentar o retângulo esboçado pelo personagem Michel, vale a pena exemplificar um dos retângulos que mais claramente mostra a idéia de Greimas. É exatamente o retângulo que dá conta dos conceitos filosóficos de essência e aparência:

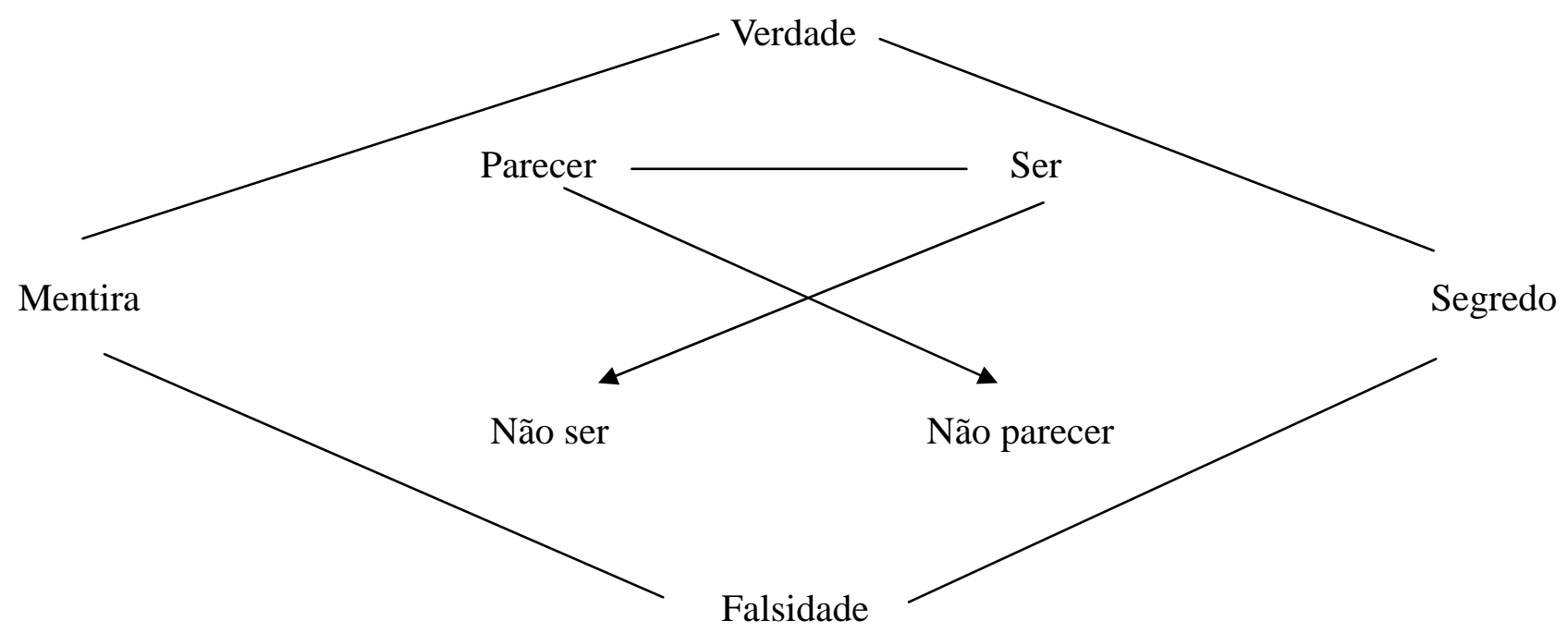

No capítulo "Homesick", Michel Duval começa a analisar o comportamento explosivo de Maya e compará-lo com os outros colonos (a estável Nadia, o fleumático Sax), quando cita os gráficos que Greimas criou com inspiração na linhagem “alquimista estrutural”, a tal combinação de elementos que geram uma terceira substância. Antes de montar o esquema dos temperamentos dos "Primeiros Cem", ele expõe o modelo três vezes didaticamente - para tanto usa até um exemplo moral e antropológico incluindo adultério, incesto e matrimônio. 
Na sequência, ele apresenta o retângulo com humores e vai falando quem se encaixa em cada vértice. Nesse momento se entrevê como Robinson foi esquemático na construção da combinação de personagens. O desenho abaixo mostra uma distribuição dos principais personagens, com base nas pistas que Duval dá no trecho, mas incluindo figuras que só entrariam na trama nos volumes seguintes. Além da posição nos vértices combinatórios, coloquei também os seres fictícios de Robinson como incorporações das qualidades "puras" de extroversão, introversão, estabilidade e instabilidade.

É revelador verificar que a estratégia formal se confirma quando o time dos sanguíneos fica desfalcado com as mortes de John Boone e Arkadi Bogdanov em Red Mars. Logo no início de Green Mars, o autor escala para a posição dois novos personagens, Nirgal e Art. Dessa forma, garante a reserva de figuras impulsivas e otimistas na trama, mas em versões mais simpáticas às corporações. A seguir o retângulo com as principais personagens:

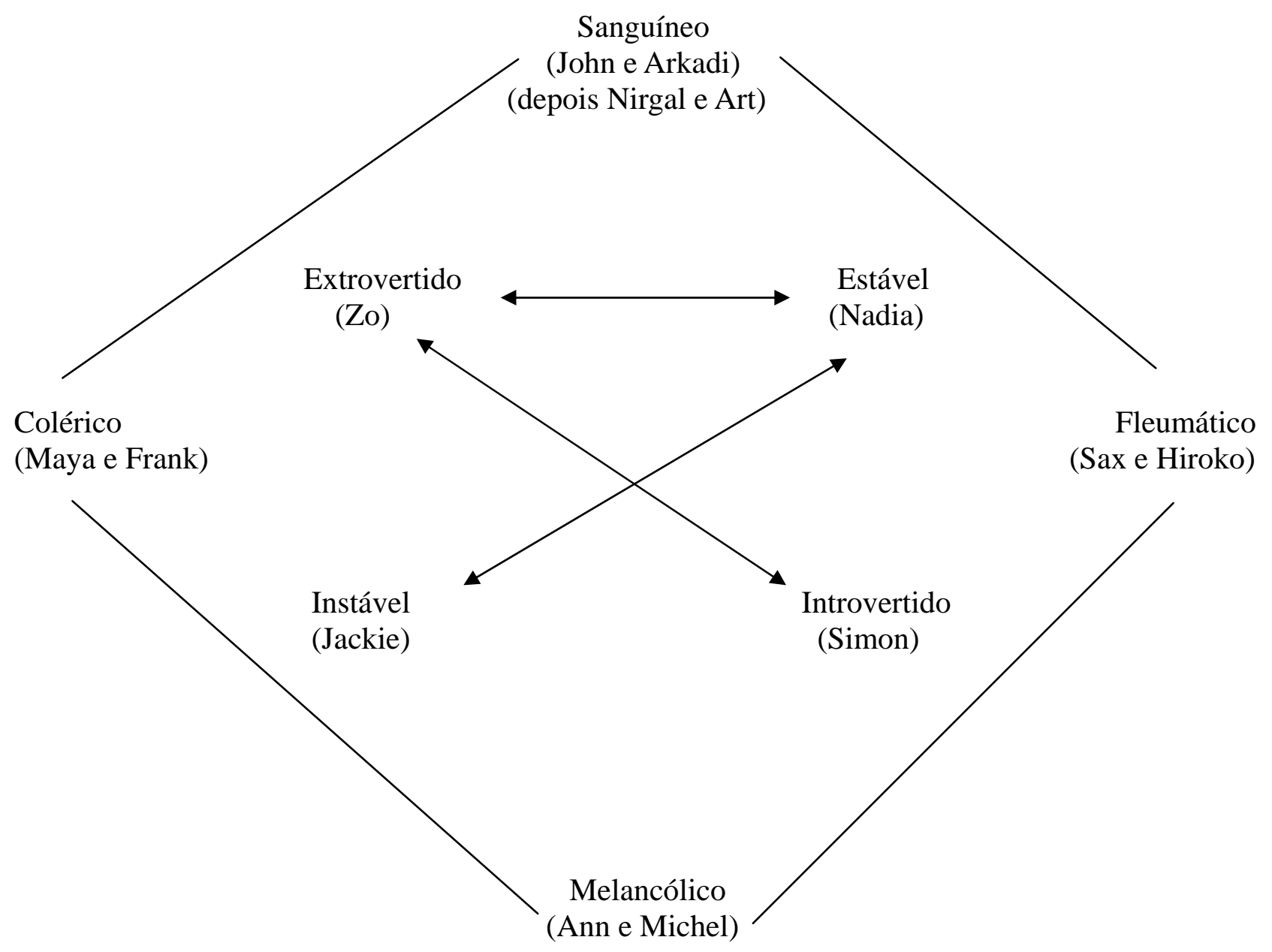


Esse mesmo esquema, que mostra a disposição por temperamentos dos convivas fictícios, esquematizando os possíveis ódios e amores pelo conceito de humor da Grécia Antiga, também pode ser aplicado nas posições diante do dilema entre transformar ou manter a paisagem marciana. Veja abaixo o esquema:

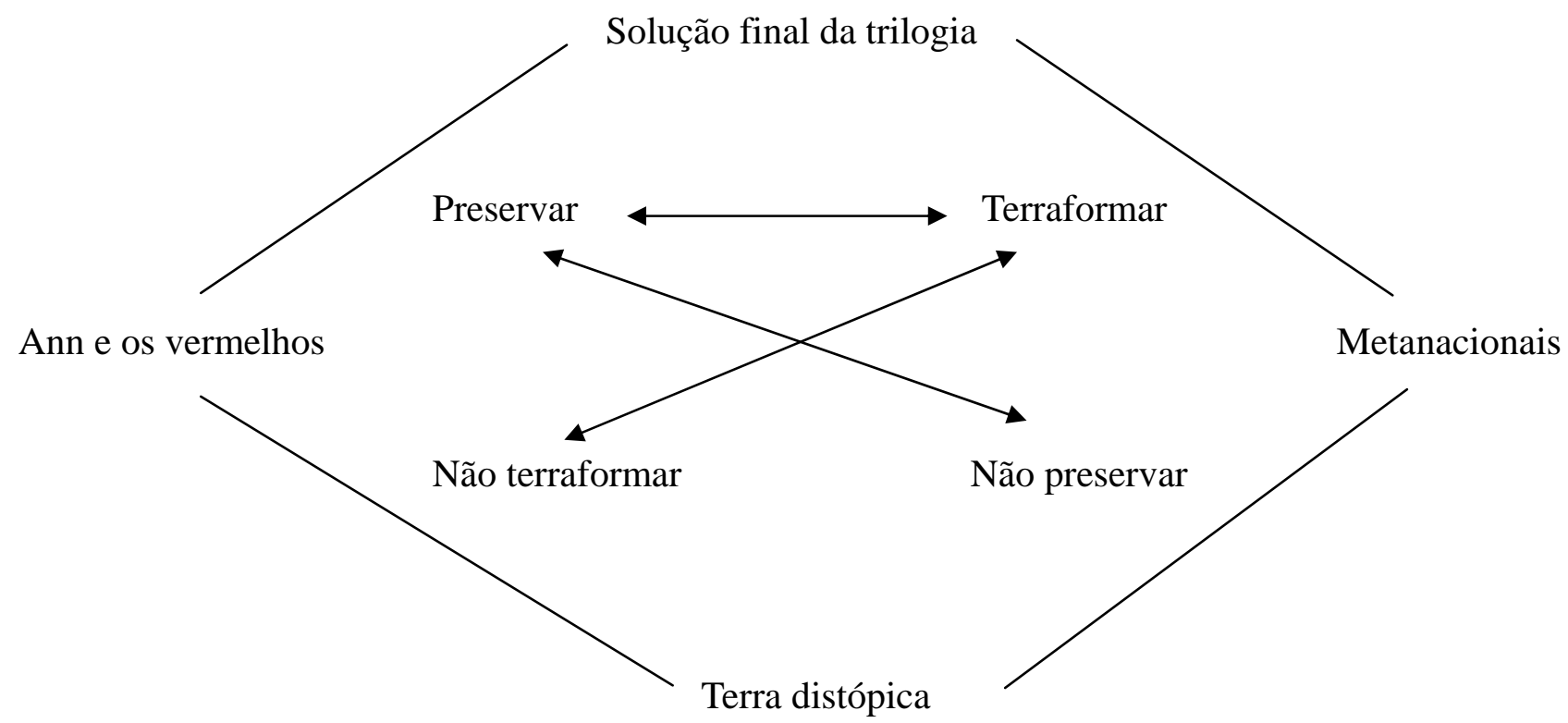

Um sonho de Ann é especialmente ilustrativo dos valores das principais figuras entre os "Primeiros Cem". Esse sonho acontece após a personagem ficar chocada ao ver o novo rosto de Sax, que assumira a identidade falsa do suíço Stephen Lindholm, para se infiltrar nos laboratórios corporativos (1994, p.171-172).

\footnotetext{
"Ao fim, apoiou a cabeça nos joelhos e caiu em uma espécie de sono. Os Primeiros Cem a rodeavam, os vivos e os mortos, Sax no centro, com a cara de antes e o perigoso novo olhar de desolação.

Sax disse: - A rede ganha em complexidade.

Vlad e Ursula disseram: - A rede ganha em saúde.

Hiroko disse: - A rede ganha em beleza.

Nadia disse: - A rede ganha em bondade.

Maya disse: - A rede ganha em intensidade emocional - e atrás dela John e Frank olhavam o vazio.

Arkadi disse: - A rede ganha em liberdade.

Michel disse: - A rede ganha em compreensão

Atrás, Frank disse: - A rede ganha em poder - e John deu uma cotovelada nele e gritou: - A rede ganha em felicidade!

E então todos olharam Ann. E ela se levantou, tremendo de raiva e medo, compreendendo que só ela acreditava na possibilidade que a rede não ganhava nada em absoluto, compreendendo que era uma espécie de louca reacionária. E só pôde sinalizar com o dedo trêmulo e dizer: - Marte, Marte, Marte.”
}

O próprio Michel, que formula os retângulos e prefigura o autor, se inclui entre os melancólicos, caracterizados como altamente artísticos, preocupados com a crueldade do mundo e perfeccionista - no romantismo, a melancolia (hoje apelidada de depressão) era considerada uma doença bem-vinda, uma experiência para enriquecer a vida. 
Muito mais que o nostálgico psicólogo, é Ann Clayborne quem é a principal figura melancólica da trilogia. Deprimida e suicida, se isola da convivência dos outros em várias oportunidades. Relatos focados nela fecham dois livros da série (Red Mars, em tom triste em um planeta em transformação e caótico; e Blue Mars, resgatando a vontade de viver em um mundo ordenado em um verdadeiro jardim com ilhas e mares, ficando o planeta original e mineral como uma reserva ecológica nas grandes altitudes).

Ela representa a ciência em estado puro, longe dos objetivos de lucro e tecnologia. Tanto que o amor dela pelo planeta é reflexo de sua convicção geológica. Como se fosse uma líder espiritual, chega a propor uma aerofania vermelha, reverenciando a paisagem mineral do planeta - repete várias vezes ao longo da trilogia a frase "o Marte vermelho se foi”, revoltada no início e resignada no final com a inexorabilidade do "progresso".

Por seu lado, os fleumáticos são tidos como observadores, amistosos, bons administradores e bons diplomatas. Entre eles, está Saxifrage Russell, que personifica a ciência aplicada. Ele sofre uma mudança de temperamento após uma cirurgia plástica e outra cerebral. De cientista "apolítico", interessado só na questão da terraformação, se transforma em sabotador para contentar seu par romântico e antagonista vermelha, Ann (mutação que corrobora a idéia das múltiplas posições subjetivas).

Outra do grupo é a ecoengenheira japonesa Hiroko Ai. Ela é o misticismo que Robinson cria, mas faz desaparecer no final da narrativa. Ela cria uma crença em tom oriental (termos xintoístas e substâncias alucinógenas das ilhas Fiji), bem na onda das novas religiões que pululam pela Califórnia contracultural - comendo terra marciana em uma cerimônia de iniciação, Michel perde a consciência e se envolve em uma espécie de orgia. A imagem de “deusa mãe” também é dada porque ela é a matriz da nova raça marciana, afinal, coletou espermatozóides dos primeiros colonos e os fecundou em seus óvulos para criar descendentes (chamados, como vimos, de ectógenos) em tanques de magnésio.

Outros dois fleumáticos são o "marxista” Vlad Taneev e o corporativo William Fort, apesar das posições opostas no espectro ideológico. Taneev é um pesquisador isolado, inventor em parceria de vários dispositivos que fazem a trama andar, como o tratamento geriátrico, a eco-economia, a operação cerebral e o tratamento de recuperação de memória - além da droga omegendorfo. Por seus feitos científicos, sua "mente brilhante" é comparada a Newton e Einstein. Outro apontado como gênio e ermitão é Fort, fundador da Práxis e guru corporativo. Personifica o empreendedor, o self made man. É chamado de "Pasteur de seu século" por ter achado a cura para o câncer e o resfriado comum, o que o deixa bilionário.

Já os coléricos são líderes atrás de saciar suas ambições como Frank e Maya. Os dois líderes dos contingentes, o norte-americano e a russa transitam na esfera da realpolitik. Frank é a incorporação do maqueavelismo, uma personagem conturbada, cínica e irritadiça. Seu nervosismo é exemplicado em cena memorável logo no primeiro capítulo em que sua raiva é canalizada para o sistema energético de Nicósia assim que toca a membrana da tenda que cobre a cidade (1993, p.19). Simbolicamente, ele morre engolfado pelo planeta, engolido pela terraformação, virando biomassa e gritando irado "go, idiot, go" "go, damn it, go".

Maya é um animal político, mas é também a personagem mais passional da trilogia. Vingativa, vaidosa e manipuladora, a sedutora russa do início da história não lida bem com a velhice e entra em conflito com a decadência corpórea (chega a raspar a cabeça para ficar com mais 
aspecto réptil) e a decadência mental (rejeita o tratamento para recuperar a memória porque não quer lembrar seu passado, principalmente seu triângulo amoroso e político com John e Frank).

Por outro lado, os catalogados como sanguíneos levam à frente: John Boone, o Adão carismático de Marte. Bom orador e aglutinador de idéias e pessoas, ele morre no primeiro livro, mas deixa para os seguintes volumes seus seguidores, os booneanos, defendendo uma solução intermediária entre as ideologias em jogo.

Outros dois desse tipo são Arkadi e Art, dois parceiros amorosos da protagonista Nadia. Arkadi representa tanto sua paixão política que até sua barba e cabelos são vermelhos, ele "era um evidente símbolo revolucionário, como se fora o jovem Fidel a ponto de entrar em Havana”. Ele é definido por Nadia como "uma força natural” e "a voz da consciência”, que posteriormente ela tenta colocar em prática com métodos menos revolucionários. E ao lado de Arthur Randolph, que é um especialista em arbitragens corporativas da Práxis, faz espionagem e lobby para essa empresa e acaba como auxiliar de Nadia na Constituinte marciana. Entre cientistas geniais, figurões políticos e a nova raça de Marte, Art é a representação do sujeito comum, típica figura que Phillip K. Dick colocaria em primeiro plano em seus livros. Estava imerso em uma vida perfeitamente ordinária em São Francisco até 2101, chefe de uma empresa de sucata e divorciando-se da mulher, até ser convocado para a missão metanacional no outro planeta.

Mas é uma personagem intermediária entre o rótulo de fleumática e de sanguínea que resume o conteúdo da trilogia marciana. Como Darko Suvin (1984) afirma, a construção de um sistema social para o leitor é, por sua vez, reconstrução do herói. E ele na trama é ela: Nadia.

Ela simboliza o sentido prático. A personagem ganha uma importância no final da história inesperada para quem ficou apenas na leitura de Red Mars. Engenheira especializada em construções em lugares gélidos, com várias passagens pela Sibéria, Nadia aparece na narrativa como um "pau-para-toda-obra”, construindo cidades, dutos e fábricas com a ajuda de robôs, que ela chama de "meus animais obedientes". Sem paciência para idéias abstratas (fica entediada com as discussões ideológicas de seus companheiros), ela segue uma fé no trabalho digna de um calvinista (se está sofrendo, trabalha que passa) ou de um stalinista (com as imagens de operários musculosos a fazer trabalho braçal). Não suporta ficar ociosa, o que é uma forma de não pensar. Prova disso é que ela se afunda no trabalho quando no pós-revolução de 2061 não sabe o paradeiro de Arkadi.

É classificada por John como “solvente universal”, por sua ação reparadora, por ter prestígio com todos e por sua imagem forte e incorruptível. Apesar de russa, mostra-se grande conhecedora de assuntos como jazz e folclore dos EUA. Admiradora de Louis Armstrong e King Oliver's Creole Jazz Band, especialmente de seus discos de 1947, trabalha assobiando essas músicas como se fosse um negro americano a construir ferrovias no século 19. Sabe sobre folclore norte-americano (discute com Arkadi, outro russo, sobre Johnny Appleseed, Paul Bunyan e Babe) e tem um perfil muito pragmático (em vários trechos, se apresenta como apolítica).

Seu nome, porém, é uma referência explícita a uma figura da história russa. O filósofo, escritor e crítico russo Nikolai Cherneshevsky (1828-1889) defendeu em seus textos que a luta de classe era o motor da história, pregou um socialismo baseado em comunas agrícolas e advogou pela emancipação dos servos. O Cherneshevsky da vida real foi influenciado pelas idéias do filósofo alemão Ludwig Feuerbach (1804-1872), famoso por sua polêmica com Karl Marx. Ele posteriormente influenciou o líder bolchevique Vladimir Lenin. Escreveu o romance cujo título, traduzido para o inglês, é What Is To Be Done? (O Que Deve Ser Feito?), que dá nome a um 
capítulo de Green Mars em que Nadia é a focada. Em Red Mars, há outro capítulo em que Nadia é a protagonista e cujo título é uma paráfrase: Senzeni Na, o que vertido do japonês para o português quer dizer "O Que Nós Fizemos”.

O livro de Chernerhevsky foi escrito na prisão czarista em 1860 e publicado em fascículos escapando da rígida censura da época. Relata uma heroína que luta contra o casamento por obrigação, organiza cooperativas, estuda medicina e vislumbra um futuro com direitos iguais entre os sexos, amor livre e tecnologia.

Outra referência (mais irônica) para Nadia é A Princesa de Marte, livro de 1912 escrito por Edgar Rice Burroughs, inventor da personagem Tarzan e autor de uma série de livros aventurescos sobre Marte. Mas Nadia é bem diferente da heroína de Burroughs, que também servirá de inspiração para o nome da capital burocrática do planeta de Robinson. Enquanto a moçoila de Burroughs é uma espécie de sedutora medusa de pele vermelha que defende uma civilização à beira da extinção, Nadia é pintada de forma bem menos atrativa. "Mais feia impossível” e "uma mulher baixa e redonda como uma pedra, de cara quadrada e cabelo curto e metade grisalho" são as opiniões estéticas de Maya sobre Nadia no segundo capítulo de Red Mars.

Mas como a cada capítulo há uma perspectiva diferente, as definições são mais generosas quando quem fala é Bogdanov em uma conversa de alcova, como no trecho que faz referência à obra de Burroughs:

\footnotetext{
“Beleza é o que você é, Nadezhda Francine. Por esse critério [as curvas] você é a rainha de Marte.”

"Princesa de Marte", ela corrige distraidamente, pensando no que ele havia dito.

“Sim, correto. Nadezhda Francine Cherneshevsky, a princesa nove-dedos de Marte.”
}

Nadia perde um dedo da mão logo no começo e culpa Maya que a desconcentrou de seus afazeres com suas histórias de amor entre John e Frank. É sintomático que Nadia perca um dedo, assim como Sax avarie seu cérebro, justamente as partes do corpo que mais contam para os dois, como duas espécies de castração. De qualquer forma, os dois problemas são sanados por procedimentos médicos de Vlad Taneev, que restaura o dedo perdido de Nadia e realiza operação para recuperar as funções cerebrais de Sax.

Sua transformação também é política. No começo, defende o capitalismo, argumentando que esse sistema é criticado porque funciona (à época de produção da trilogia reinava o neoliberalismo que prometia um desenvolvimento que depois se frustrou). Nadia se mostra contra soluções radicais, mas depois do romance (com direito a primeira noite de amor em um dirigível) e das conversas com Arkadi vai mudando de posição. Viúva, como Maya, acaba cumprindo a missão de seu mártir e promovendo a tão esperada revolução. Com a ajuda de seu novo parceiro, Art, ela acaba implementando a utopia. Justo ela que é a que menos pensava na história, só queria resolver os problemas pela frente, sem olhar para os lados, pura mentalidade engenheira.

Mas essa opção pelas personagens práticas no lugar dos idealistas é de Robinson. Ele explica em entrevista à revista Infinity Plus (GEVERS, 1999): "Eu sou muito insistente no compromisso, tolerância e moderação, exceção feita a certos temas em que eu suspeito que você tem que seguir firme em seus princípios. Isso é um dos desafios que qualquer sociedade que estiver atrás de condições utópicas terá que encarar. Eu penso que isso é a contribuição de Nadia e Art ao processo.” 
Nas últimas páginas da trilogia, Nadia, depois de sua passagem como presidente de Marte, aparece como uma matriarca de família em um almoço ao lado de Art, a filha de ambos, Nikki, o genro e os netos. A caminhada de Nadia é a trajetória da sociedade marciana imaginada por Robinson.

\subsection{O Narrador}

Ao colocar o foco em determinada personagem, o narrador dá profundidade a ela, relata seus sentimentos e impressões. O narrador se aproxima e se identifica com ela, por vezes resvalando em um discurso indireto livre, confundindo suas opiniões com as da personagem perseguida. $\mathrm{O}$ contador da história é um tipo de "maria-vai-com-as-outras", o que cai como uma luva em uma ficção científica que se propõe a expor utopias e não escolher uma delas.

O narrador de Robinson embarca nas idéias da personagem que ele escolta e se posiciona na sua perspectiva e na sua visão de mundo quando está em seu encalço. Aderem tanto que parece que estão falando em uníssono. Assim, o narrador é mais científico quando está com Sax, é mais contemplativo com Ann, mais prático com Nadia, mais sentimental com Maya e Michel. Por isso, a escolha de seguir tal ou qual personagem mostra a mão do escritor por trás dessa figura.

É um narrador que penetra na consciência das personagens, como nos sonhos cruzados entre Frank e John, ou nos pesadelos da atormentada Ann e seu planeta vermelho que desaparece.

Além dessa dimensão microscópica, o narrador também tem um ângulo orbital, descrevendo a geografia de Marte como se estivesse em órbita ou com um mapa na mão (desses muitos que estão estampados na trilogia). Aliás, os volumes começam com mapas da superfície marciana, num misto de ciência (as últimas revelações sobre o planeta estão estampadas no desenho de sua geografia de crateras, vulcões e planaltos) e ficção (como são as cidades imaginadas por Robinson).

Por essas duas características, a aparição na narrativa de quebras para falar de lendas folclóricas como o "pequeno povo de Marte” e o “Grande Homem” servem também como prefigurações desse narrador. Os seres diminutos são descritos como habitando o ombro de John Boone e falando ao ouvido do protagonista. Seria esse narrador que registra os sonhos, os pensamentos e a perspectiva da personagem. Já o "Grande Homem” seria o narrador das questões globais, da perspectiva ampliada, da localização geográfica, dos deslocamentos físicos.

Por outro lado, a constante troca de ótica gera uma mudança considerável como são percebidas as personagens, que assim como as ideologias do livro, são vistas por diversos ângulos, o que aumenta a complexidade de ambos.

Apenas para ficar nas impressões estéticas, e não pular direto para as ideológicas: Maya quando velha se vê com cara de tartaruga, mas, quando é Michel a personagem focada, ela aparece toda atraente ("a graça felina do corpo largo e musculoso de Maya, velho pela idade, mas em muitos aspectos o mesmo de sempre”). O mesmo acontece com Nadia, uma gordinha grisalha para os olhos da amiga Maya, mas que vira uma princesa de Marte aos olhos de Arkadi. Ou seja, quando a visão acompanha os nativos Nirgal e Zo, os "Primeiros Cem" ganham aparência de lagartos geriátricos, mas parecem ter recebido um tratamento com botox e lifting quando é um deles no foco da descrição, com direito a corpos sensuais aos 150 anos de idade. 
Além das rugas, quem sempre está fora do foco perde algo mais nessas tomadas de posição. Um exemplo claro é Jackie. Ela sofre oposição das três personagens femininas mais privilegiadas da história: Nadia, Ann e Maya. Apenas Nirgal tem uma visão mais positiva dela, afinal, teve um namoro na adolescência e mantém uma paixão latente por ela até o fim. Sem o foco também, o radical Arkadi também acaba estereotipado, enquanto a mística Hiroko teria aparecido mais na trama se ganhasse um pouco mais de atenção do narrador, já que, em mais da metade do enredo, a senhora japonesa não se encontra - talvez Robinson não quisesse exagerar dando uma solução mística ao estilo Ursula Le Guin e outros autores de ficção científica.

Mas o episódio que mostra mais claramente a limitação do tipo de narrador escolhido por Robinson é o relato do tratamento que os pioneiros se submetem para recuperar a memória no final do terceiro volume, tendo como cenário o Underhill, primeira colônia marciana. O foco escolhido é Sax, e ficamos sabendo dos efeitos que o coquetel de substâncias e as ondas eletromagnéticas têm sobre ele. Mas o flashback coletivo é negado pela forma. Sax insinua uma telepatia para enxergar os efeitos em Coyote e tenta interpretar o que acontece com Nadia, afinal, em sua alucinação, ela corre para as maquinarias que foram sua felicidade nos primeiros anos no astro vizinho. A solução, contudo, é manca, porque se baseia em ilações de um personagem e lança mão até uma comunicação mental, quando o mais efetivo seria que o narrador pudesse fugir do formato e captar as sensações de cada personagem envolvido. O curioso é que Robinson adota o narrador desfocado no prefácio em itálico do capítulo seguinte (o último da trilogia), quando é hora de mostrar os festejos pela terceira revolução marciana, para mostrar a euforia coletiva com o fato.

O narrador sobre os ombros de uma personagem também tem o efeito de aproximar ou distanciar a narração das ações. Mas Robinson prefere o segundo procedimento. As duas primeiras revoluções em Marte, por exemplo, são vistas pelo campo de visão de Nadia. Na revolta de 2061, ela se dói pela destruição de boa parte do que construiu até ali e depois sai em busca de seu amado entre os escombros, Arkadi, uma das baixas do conflito. Já na batalha de 2127, ela acompanha os acontecimentos por uma tela da televisão.

Os acontecimentos da primeira revolução são antecedidos pela narração atrás de Frank Chalmers, que tenta conter a iminente revolta. E só se desloca para o revolucionário Arkadi na introdução do capítulo seguinte (o sétimo de Red Mars, sob o título "Senzeni Na"), de apenas cinco páginas, mas suficientes para ilustrar a devastação da contra-ofensiva, com direito a narração de seu corpo sendo incinerado, em uma cena digna dos morticínios de Pompéia ou Hiroshima: "Enquanto lutava para ficar em pé viu que tudo se incendiava simultaneamente, as pessoas ardiam como tochas e justo diante dele seu braço estava em chamas” (1993, p. 476).

O efeito do afastamento do olho do furacão é exemplificado de forma categórica na passagem em que John está perambulando pela paisagem antes da revolução de 2061 (1993, p. 283).

\footnotetext{
"Rodou em direção oeste no piloto automático, subindo e descendo dunas sem ver nada, imerso na tentativa de entender o que era exatamente a história. E teve a impressão, enquanto continuava viajando um dia depois do outro, de que a história era como essa vastidão que sempre estava atrás do estreito horizonte, invisível exceto por seus efeitos. Era o que acontecia quando não se está olhando: uma desconhecida infinidade de fatos descontrolados que controlavam tudo.”
}

Isso mostra que a ação apresentada pelo narrador deixa fora do enquadramento a agência que opera por trás justamente quando a história dá uma guinada. John vê só os efeitos colaterais, as fraturas, como nos atos violentos que sofre, na repressão policial e, durante sua investigação, nas 
opiniões que as outras personagens têm da conjuntura. John só consegue vislumbrar a proporção do que está acontecendo quando está na reunião no Monte Olimpo, no final do mesmo capítulo, que se chama "Falling Into History” (Caindo Na História).

Uma exceção que só confirma a regra é o resgate de Sax, que ganha em adrenalina por ser relatado a tiracolo de um dos partícipes da ação (no caso, Michel).

Uma maior liberdade nesse engessamento narrativo se dá nas introduções dos capítulos, textos formatados em letra itálica que garantem uma fragmentação maior ainda à obra de Robinson. Esses textos podem ser complementares, contrastantes ou aparentemente desconexos do texto principal do capítulo. São neles que o escritor se permite mais liberdade formal, fugindo um pouco do narrador em terceira pessoa perseguindo as personagens. Um exemplo disso é a introdução polifônica ao capítulo “Armas Sob a Mesa”, com depoimentos sobre onde as pessoas estavam na hora da morte de John Boone, como uma repetição do mesmo fenômeno em torno do assassinato do ex-presidente dos EUA John Kennedy em 1963.

Outro expediente desse narrador apartado é penalizar os momentos de distensões com más surpresas, como se toda distração gerasse uma punição, todo prazer desviasse a atenção necessária, toda a queda na rotina acabasse com uma guinada histórica inesperada.

Nessa lógica, Nirgal e Jackie faziam sexo em uma colina quando explode o contra-ataque das transnacionais em Green Mars (1994). Maya e Michel desfrutavam de temporada na Provença quando recebem a notícia que Nirgal está convalescente. Art e Nadia protagonizavam uma cena doméstica digna de comercial de margarina, quando chega a notícia que Jackie e seu grupo desobedecem pela primeira vez a constituição recém-aprovada. Sax e Ann relaxavam em um romântico cruzeiro marítimo quando a tropas das Nações Unidas retomam o elevador espacial em Blue Mars. A sensação que o gozo particular é seguido do castigo coletivo lembra que é preciso estar em constante vigilância.

O narrador também compartilha com as personagens uma bagagem cultural e científica muito semelhante. A teoria citada por um deles é logo explicada pelo contador da história. Arkadi Bogdanov se refere a pintores e escritores em suas falas, como faz o próprio narrador diversas vezes. Logo se vê que o autor, o narrador e os outros personagens parecem ter uma trajetória similar, com passagens pelo ambiente acadêmico e o universo da ficção científica, como a próxima parte da dissertação sugere. 


\subsection{Estilos e citações}

Assim como troca de personagem, o narrador também ao longo das quase 2.000 páginas da trilogia alterna gêneros, algo comum na ficção científica. Tem policial noir, romance de formação, relato de viagens, fábula mitológica, literatura psicológica, space opera e muita descrição técnica que parece saída de manuais de uso.

A novela detetivesca é garantida por John Boone investigando sabotagens e atentados e tendo de lidar nesse percurso com policiais truculentos e grupos que querem eliminá-lo. Lá estão todos os ingredientes do gênero: o detetive oscilando entre a lei e o crime, ar sombrio das locações (no caso, escritórios ou laboratórios), o uso de substâncias entorpecentes (o omegendorfo, droga com endorfinas e opiáceos naturais, no lugar do uísque), as ciladas (como os policiais da UNOMA plantando um cadáver em seu quarto). O clima de suspense é proporcionado pelas sucessivas tentativas de assassinato e pela insistência da polícia em tentar a todo custo interrogá-lo e depois incriminá-lo. Mas a narrativa segue a la Robinson, ou seja, com muita discussão e diálogo em meio à ação.

Aparece também um romance de formação, com Nirgal criança descobrimento o mundo, o sexo, a morte e sua origem. Os relatos mítico-fantásticos estão presentes nas histórias sobre o Grande Homem, Paul Bunyan e os pequenos homens vermelhos.

Tem passagens que parecem road movies (as filosofias na paisagem proporcionadas pelas expedições de Ann ou pela fuga de Coyote, Art e Nirgal levando Sax ferido) ou literatura de viagem (John Boone visitando os sufis ou Nirgal conhecendo a Terra).

Há também uma série de plots que parecem saídos de algum filme-catástrofe, colocando as personagens em apuros no ambiente inóspito de Marte, mas eles servem apenas para criar um suspense, afinal, as personagens em geral se salvam - a exceção é a morte de Frank, levado, como vimos, por uma inundação. Mas, em outros episódios, a aventura meteorológica acaba com as pessoas se salvando por pouco, como Ann escapando de deslizamento e do urso polar, Sax e Phyllis se livrando de um poço no gelo ou Sax e Ann saindo sãos e salvos de uma tempestade em alto mar.

O exercício da colagem também se estende às citações diretas e indiretas de autores e obras. O mais evidente é o entrecho proustiano de Michel e Maya sobre memória involuntária, mas há tons dickensonianos na aventura inglesa de Nirgal, isso sem falar da proximidade evidente entre Zo e Dorothy, do Mágico de $\mathrm{Oz}$ - o nome dela é uma inversão do título da história, além do narrador citar a famosa frase ("There's no Place Like Home”) no capítulo que se centra na jovem.

Um certo tom professoral, aplicado principalmente nas dezenas de citações científicas como as teorias das supercordas, gene egoísta e o processo Bosch, o narrador também utiliza para descrever a geografia marciana ao estilo célebre de pintores, como o surrealista belga René Magritte ("as rochas negras isoladas que descansavam no gelo como esculturas de Magritte”), o paisagista inglês J.M.W. Turner ("Várias vezes o céu parecia em chamas, como uma cena de apocalipse de Turner”) e o ilustrador norte-americano Maxfield Parrish (“A linha de nuvens amarelas e rosadas derivou por um céu de azul pastel: parecia um pesadelo de Maxfield Parrish”). Descreve também a cúpula da cidade de Stickney "brilhava como um ovo Fabergé” durante queda do satélite Fobos.

As referências musicais também pontuam a trilogia, como a cena no Ares em que uma 
tempestade radioativa do espaço é acompanhada ao som de uma sinfonia de Beethoven. Nadia é a personagem mais musical, adoradora de jazz. O ritmo ressalta sua personalidade voltada ao trabalho e ela geralmente canta ou assobia temas durante suas horas de trabalho, como "The Sheik of Araby”, música de filme de Rudolph Valentino, enquanto aperta parafusos no frio marciano.

As colagens literárias também se sucedem com o narrador falando de As Viagens de Gulliver, de Jonathan Swift, e Frankestein, de Mary Shelley. As personagens também fazem referências, como Arkadi Bogdanov lembrando os livros de George Orwell ou os desenhos do holandês Maurits Escher (conhecido por ilustrar ilusões de ótica, geometrias impossíveis e jogos de imagens em que brinca com a perspectiva). Também Maya Toitovna encena na cidade de Odessa a peça $O$ Círculo de Giz Caucasiano, de Bertold Brecht.

Há também um "tributo" a T.W. Lawrence, autor de Seven Pillars of Wisdom (Os Sete Pilares da Sabedoria), no qual o militar britânico que ficou conhecido como Lawrence da Arábia conta sua participação junto aos árabes no conflito contra o Império Otomano durante a Primeira Guerra Mundial: as referências estão lá nas visitas de John Boone e Frank Chalmers às tendas islâmicas e a transposição das facções Ahad e Fetah daquele contexto colonial do início do século 20 direto para Marte do final do século 21.

Mas a personagem com as paráfrases mais interessantes é Frank Chalmers. Há um trecho em que reescreve a fábula de Walter Benjamin do anão que joga xadrez escondido dentro do autômato (alegoria da teologia operando por dentro da filosofia). Frank descreve sua atitude dissimulada frente a Maya "era como um anão metido dentro de um waldo (máquina de manipulação remota)”.

A paráfrase mais cheia de sentidos é a que foi pinçada por Jameson para dar título a seu ensaio sobre a trilogia: "If I Found One Good City I Will Spare The Man" (Se Encontrar Uma Cidade Boa Eu Salvarei o Homem). A frase aparece em discurso livre indireto, no meio da descrição do narrador, como um pensamento de Frank, personagem atormentada que cria tumulto jogando pedras na multidão e incitando os árabes a matar John. Ao mesmo tempo, espera um gesto de Maya que o faça parar esse ímpeto.

A frase é uma inversão de passagem da Bíblia, mais especificamente dentro do Livro do Gênesis, que conta a destruição de Sodoma. Deus aparece para Abraão e conta que vai destruir a cidade devido aos tantos pecados de seus habitantes (além da sodomia que dá nome a localidade, existe por lá ainda injustiça social, orgulho, alimentação excessiva, tranqüilidade ociosa e desamparo aos pobres e indigentes). Abraão argumenta que há pessoas boas por lá, mas Deus fala a frase transformada por Robinson: se encontrar 50 homens bons, eu salvarei a cidade. O número vai baixando até 10 , mas não chega a tanto a quantidade de gente de bem por lá. O único que se salva é Ló, levando suas filhas, depois de ser avisado pelos anjos. Enquanto Ló escapa, Deus lança pedras contra Sodoma, como Frank joga na população de Nicósia.

Entre outras interpretações, a frase lapidada por Robinson pode ser lida da seguinte maneira: "não são os homens que salvam as cidades, mas as cidades que salvam o homem". Ou seja, a redenção da humanidade não virá de um salvador, mas por pensar e criar sociedades que visam o bem comum, lógica que corrobora a idéia de federações de utopias que Robinson e Jameson defendem.

E na própria resenha "If I Found One Good City I Will Spare The Man”, Jameson aponta outras referências, como o diálogo que Robinson tem com seus antecessores no gênero, como as 
semelhanças com Olaf Stapledon (os exageros visuais na descrição de Mercúrio, Vênus e outros locais de terraformação em Blue Mars) e com Ernest Callenbach (sua Ecotopia e a possibilidade de ritos arcaicos de violência como válvula de escape).

Mas um paralelo mais revelador é com Ursula Le Guin, a autora que Robinson mais admira. O ponto mais direto é o capítulo que relata a viagem de Nirgal à Terra em relação a situação similar em The Dispossessed e o efeito de estranhamento da visão alienígena. No livro de 1974, o viajante Shevek descreve as sociedades do planeta Urras (vivendo uma Guerra Fria entre um bloco capitalista e outro socialista) e de sua lua anarquista Anarres. Apesar de uma posição mais simpática em relação ao astro que segue uma utopia próxima à projetada por Pyotr Kropotkin, Le Guin mostra com o subtítulo da obra "An Ambiguous Utopia” um distanciamento da fórmula de Anarres. A autora problematiza a questão da sociedade ideal e fica a impressão ao final do livro que tal coisa não é algo possível, apesar da ajuda mútua e da cooperação existente no satélite anarquista. É uma outra forma de expor o problema da sociedade ideal inatingível diferentemente do que Kim Stanley Robinson fez, imaginando um planeta com uma coleção de utopias à disposição do habitante - o autor mais recente arrumou uma solução mais condizente com a ideologia de seu tempo, mas nem por isso mais bem elaborada.

Outro diálogo citado por Jameson é com Robert Heinlein (1907-1988), autor dito como o artífice do estilo norte-americano de fazer ficção científica. Classificado como um escritor de direita (alguns apontam seu militarismo), Heinlein explorou uma série de temas em suas obras que encontraram eco ou resposta na trilogia de Robinson, um ficcionista que dentro do espectro político dos EUA pode ser chamado de left wing.

Em uma das “inspirações” de Robinson, Heinlein montou uma tabela de duas páginas com a cronologia de fatos do que ele imaginou como "História Futura”, que ia de 1940 a 2140. A partir dessa linha do tempo, ele foi encaixando seus relatos posteriores.

Em outro livro que ganhou "tributo" na trilogia marciana de Robinson, em 1941 ele escreve Methuselah's Children, sobre um grupo de homens que sofre tratamento, vivem uma vida longa e que são hostilizados pelo resto da humanidade que quer saber o segredo. Já em Stranger in $a$ Strange Land, de 1961, apresenta um humano crescido em Marte que viaja à Terra e oferece opiniões pungentes, filosóficas e até ofensivas - qualquer semelhança com a personagem Nirgal não é mera coincidência. Outro paralelo é com The Moon is a Harsh Mistress, de 1966, que conta a história de uma revolução promovida pelos colonos do satélite, com diversas referências em seu enredo à Guerra de Independência dos EUA, mesma influência que Robinson teve para descrever seus revoltosos de Marte

Mas há também conexões com Frank Herbert (Duna) e Isaac Asimov (Fundação). As referências a Philip K. Dick estão em várias partes, como no lapso de tempo no dia marciano (ele escreveu um livro com o título Martian Time-Slip) e na semelhança entre os ectógenos e os precogs de Minority Report (assim como os bebês das castas inferiores são colocados em incubadeiras com pouco oxigênio em Admirável Mundo Novo, de Aldous Huxley). O diálogo com a tradição sci-fi inclui também a inspiração em Shambleau, de C.L. Moore (1911-1987), como exemplo para o discurso de John que abre a trilogia.

Outra citação vai para Charles Sheffield, escritor que morreu durante a escritura da trilogia e que recebeu especial agradecimento impresso nos livros de Robinson. Entre outros detalhes (Sheffield é nome de uma das principais cidades marcianas), a homenagem está na introdução, 
destruição e nova construção do elevador espacial em Marte. No final da década de 70, Sheffield e Arthur C. Clarke publicaram romances (respectivamente, The Web Between The Stars e The Fountains of Paradise) que giravam em torno de um elevador espacial, idéia que foi desenvolvida pelo engenheiro russo Yuri Artsutanov para facilitar o transporte de pessoas e equipamentos para fora da órbita, dispensando os foguetes. Até agora o projeto não prosperou, mas como Clarke previu décadas antes, as telecomunicações via satélite, uma banalidade hoje em dia, ficou a aura de premonição patenteável (aliás, o autor de 2001 foi homenageado também na obra de Robinson dando nome a duas cidades lunares, Clarke e New Clarke).

Outra similitude é com as idéias de Charles Fourier. Fora a já citada referência aos falanstérios para a concepção do edifício comunal dos bogdanovistas (privilegiando as áreas coletivas aos espaços privados), o choque é tremendo para quem lê Walter Benjamin escrevendo sobre o socialista utópico francês em sua $11^{a}$ tese de "Sobre o Conceito de História".

Nesta tese, Benjamin foca nas visões social-democrata, marxista vulgar e positivista sobre o trabalho, analisando como esse conceito é mais associado à dominação da natureza que à exploração do proletariado: “Ao lado dessa concepção positivista, as fantasias de um Fourier, tão ridicularizadas, revelam-se surpreendentemente razoáveis. Segundo Fourier, o trabalho social bem organizado teria entre seus efeitos que quatro luas iluminariam a noite, que o gelo se derreteria dos pólos, que a água marinha deixaria de ser salgada e que os animais predatórios entrariam a serviço do homem. Essas fantasias ilustram um tipo de trabalho que, longe de explorar a natureza, libera as criações que dormem, como virtualidades, em seu ventre.”(1985). Pois, os sonhos de Fourier acontecem na trilogia, só trocando Marte pela Terra como locação.

O interessante na trilogia é quem realiza esse trabalho hercúleo e transformador: o cientista, que personifica o estereótipo da potencialidade do trabalho não-alienado e produtivo. 


\subsection{O cientista como herói revolucionário}

O catálogo de satélites artificiais, mutações biológicas e equipamentos robóticos dão um ar de livro de divulgação científica à trilogia de Robinson, trazendo as informações mais recentes (para a época) e utilizando no enredo teorias de áreas novíssimas, como a planetologia. E são esses livros da chamada popular science que propagam atualmente a imagem positiva dos cientistas.

No planeta Marte de Robinson, os robôs e máquinas fazem o trabalho braçal, acelerando a velocidade e a quantidade de realizações humanas por lá. Eles constroem cidades, dutos, estradas, fábricas, fazem buraco até o manto do planeta, conectam o elevador entre Marte e os satélites, mas no capítulo distópico de Red Mars, o sexto, aparecem trabalhadores explorados trabalhando em péssimas condições, greves e estivadores fazendo trabalho de carga que deviam ser realizados por robôs.

A mão controla à distância e intervém diretamente em situações de emergência - a personagem de Nadia, sua fixação com o trabalho e a perda de um de seus dedos é símbolo disso que Fourier imaginava. Mas o pensador utópico mais associado com a idéia de veneração da ciência prática é outro. "Saint-Simon é o profeta dos engenheiros e da produtividade industrial, igualmente aplicável no capitalismo controlado e no socialismo autocrático. O Canal de Suez, em igual medida que Stalin, e todas as obras de ficção científica onde o herói seja um engenheiro "ideologicamente neutro" a cargo da organização - desde Verne a Asimov, ou de Bellamy a Wells utópico, mas frágil - são sansimonianos”, escreveu Suvin em seu livro já citado (1984, p.159-60).

Não por nada os políticos conservadores são especialistas em se fantasiar de engenheiros, colocar capacete plástico de proteção e fazer fotos e vídeos em construções para fingir que são mestre de obras (junto com o modelo vem o discurso gerencial, também pretensamente neutro "não sou de direita nem de esquerda, sou pela eficiência, pelo choque de gestão”).

Esse mito da neutralidade dos engenheiros é criticado em seu cerne por Adorno no texto "Mensagens numa Garrafa”, mais exatamente na mensagem de número dez, em texto que faz comparação com seu total oposto, o idealista. "O dissidente totalmente regido pelos fins é hoje tão completamente desprezado como um 'idealista' e um sonhador, que fica mais inclinado a imputar poderes redentores a sua excentricidade do que a reafirmar sua impotência como impotente. Decerto, porém, que não se pode depositar maior confiança naqueles que estão em sintonia com os meios - os seres sem sujeito, impotentes para corrigir a injustiça histórica, adaptados à tecnologia e ao desemprego, conformistas e sórdidos, difíceis de distinguir dos falastrões do fascismo (...) ambos os tipos são máscaras teatrais da sociedade de classes, projetadas no céu noturno do futuro, e os próprios burgueses sempre se deleitaram com seus erros, assim como com sua irreconciliabilidade: de um lado, o rigorista abstrato, esforçando-se impotentemente para realizar quimeras, e de outro, a criatura subumana que, descendente da desonra, nunca poderá evitá-la.”

Na lógica burguesa que goza separando os meios dos fins, os engenheiros são esses "seres dos meios” e suas representações na trilogia marciana são Nadia e seus seguidores. São especialistas em criar meios para que as coisas aconteçam, mas de tão chafurdados na dita realidade (nada mais ideológico do que falar "você pode ver por si mesmo como são as coisas" e "deixe os fatos falarem por si”) eles edificam lugares ideais que cumprem apenas uma função analgésica do presente.

Com as revoluções fracassadas, a filosofia pragmática vence tendo os engenheiros na 
vanguarda. Ou seja, a mensagem por trás é “vamos ser práticos.”

Art Randolph, que termina como marido de Nadia, é ápice da ideologia acima, afinal, ele próprio se define como "engenheiro social”, devido a sua especialidade em arbitragens públicas. Esse tema é revelador de um dos limites extremos em que chegou o liberalismo norte-americano, que privatizou até sua Justiça, com empresas de mediação resolvendo casos envolvendo duas corporações ou processos de consumidores e empresas (na assinatura do contrato já aparece o nome do tribunal particular, muitas vezes ligado ao mesmo grupo capitalista, o que de cara já mostra que o cliente tem poucas chances diante do possível litigante). Ou seja, empresas julgam o que outras empresas fazem (um monopólio dos meios e dos fins), e até o papel mediador é retirado do Estado.

Adorno sentencia que meios e fins foram reificados no pensamento burguês, "os fins como 'idéias' cujas esterilidades residem em serem incapazes de se externar, sendo essa irrealizabilidade habilmente dissimulada como implícita no absoluto, e os meios como 'dados' da mera existência sem sentido, a serem classificados, conforme sua eficácia ou falta dela, como seja lá o que for, mas desprovidos de razão em si.” (2001). O filósofo alemão diz que essa antítese só é válida para o mundo que a produziu, mas não serve para o esforço de mudança.

E dentro desse raciocínio, Adorno se coloca, ao contrário de outros colegas oriundos da Escola de Frankfurt, em uma posição crítica às utopias. "Quem é versado na teoria dialética reluta em se entregar a imagens positivas de uma sociedade adequada, de seus membros e até dos que a aprimorariam. Os vestígios do passado impedem-no de fazê-lo; em retrospectiva, todas as utopias sociais, desde a de Platão, fundem-se numa desalentadora semelhança com aquilo contra o qual foram concebidas. O salto para o futuro, passando por cima das condições do presente, aterrissa no passado. Em outras palavras, não é possível formular os fins e os meios isolando-os uns dos outros"(2001).

Os cientistas são outras figuras que, apesar de seus rigores éticos, têm dificuldade em lidar com os fins dados aos meios que inventam. Na trilogia marciana, o cientista Sax, com seus espelhos orbitais e luas artificiais, representa esse trabalhador superpoderoso. Como o italiano Galileu Galilei, ele é o cientista prototípico, que olha atenta e demoradamente para as coisas a fim de entender o porquê e seus mecanismos, como fazem os literatos e o críticos para escrever sobre as ficções.

Símbolo da insistência da ciência contra os dogmas religiosos, Galileu também é a representação do intelectual revolucionário em suas descobertas, mas que não está disposto a posar de mártir e se retrata diante dos inquisidores. Sua figura cala fundo numa atualidade como a nossa em que as revoluções são só as científicas, uma época em que não há mais causas para as quais morrer, em que não há adesões ferrenhas, em que não se sabe exatamente onde se está parado, em que o confronto de forças se mostra tão pouco parelho que se pode anunciar uma mudança, mas não se vai às últimas conseqüências para defendê-la diante dos inquisidores modernos. Isso explica como Robinson acena com heróis revolucionários em Red Mars, mas em Blue Mars faz sua retratação pública (ele diante do leitorado norte-americano, como Galileu na frente da Santa Inquisição). É revelador que a última página tenha uma citação do murmúrio do italiano após o julgamento (o famoso Eppur Si Muove) para “dizer o que deve ser dito e continuar ali” sem ir para a "fogueira em nome da verdade, o que seria uma estupidez".

Isso, levando em conta que o cientista carrega consigo o mito do trabalhador não-alienado, aquele que sabe o que está fazendo e tem controle dos fatores em jogo. Essa impressão fica só na mitologia, afinal, os resultados sempre escapam de seu controle, como na cena típica do cientista 
maluco que explode o laboratório ou no enredo verdadeiro dos criadores da física atômica e o resultado em ogivas militares de destruição em massa.

Ocorre isso porque em nossa época a ciência substituiu a política como vetor da mudança. O dinamismo da sociedade científica cria a ilusão que só lá as coisas acontecem, rápida e eficientemente. Contudo, a ficção também se encarrega de criar os cientistas malucos, que explodem laboratórios atrás de elixires para salvar a humanidade, uma metáfora que a mudança nem sempre ou quase nunca está sob controle. O mais célebre é o protagonista de Dr. Jekyll and Mr. Hyde, de Robert Louis Stevenson, mas um exemplo mais recente é o psiquiatra do livro The Leathe of Heaven, de Ursula Le Guin, que tenta guiar os sonhos paranormais de seu paciente para transformar o mundo, mas suas boas intenções acabam resultando em um cenário distópico.

É revelador notar que os cientistas forjam uma utopia em Marte que na Terra, superpovoada e oprimida, não é possível. A história de Robinson acaba de forma distópica para o planeta original dos humanos - os terráqueos só vislumbram como solução migrar, não enxergando uma mudança por lá, o que seria tirar as metanacs do poder.

Ou seja, os cientistas cumprem o papel revolucionário que a tradição marxista reserva para o proletariado - justamente os cientistas, que historicamente minaram a força da classe operária na produção, como salienta Roberto Schwarz, no prefácio do livro Colapso da Modernização, do pensador alemão Robert Kurz (1993). Ao falar da tal "revolução eletrônica" e do desemprego tido como estrutural, ele escreve: "A novidade da presente crise vem da incorporação da ciência ao processo produtivo, a partir da qual o peso da classe trabalhadora (...) entra em declínio. Assim, contrariando o outro prognóstico de Marx, a crise do capitalismo se aguça no momento mesmo em que a classe operária já não tem força para colher seus resultados.”

Ou a questão é não se falar mais em luta de classes como pensam os auto-intitulados pósmarxistas, capitaneados por Ernesto Laclau e Chantal Mouffe, que acreditam que outros antagonismos são necessários e estão na ordem do dia para uma democracia radical e um pluralismo agnóstico que eles apontam como sua utopia - o entrecho multicultural da trilogia tem um quê desses ingredientes. O argentino Laclau e a belga Mouffe, co-autores de Hegemony and Socialist Strategy, atuaram no movimento estudantil dos anos 60 e em suas obras acadêmicas rejeitaram o determinismo econômico de Marx para içar outros confrontos sociais como protagonistas das mudanças políticas, idéia na qual os cientistas poderiam ganhar um papel maior que o de coadjuvantes históricos. A dupla pós-marxista importou da análise literária os eixos de simultaneidade e contigüidade para mostrar como os diversos grupos se associam ou se repelem para atingir seus objetivos políticos particulares, com sujeitos adotando diversas posturas dependendo da conjuntura. Essas idéias se aproximam das tais "múltiplas posições subjetivas”, que caracterizariam a sociedade pós-moderna e o capitalismo tardio - termo este criado na década de 70 pelo economista alemão Ernest Mandel (1923-1995) para classificar a última onda de desenvolvimento do sistema econômico resultante dos avanços eletrônicos (seguindo a lógica, a atual Era Digital poderia estar inaugurando um novo estágio, multiplicando os efeitos de sua aparente imaterialidade de tal forma que a quantidade de realizações geraria uma nova qualidade, um novo tipo de expressão cultural).

Por essas e outras razões, a visão dos cientistas como classe revolucionária é tão polêmica há quem os rotule como a primeira classe social globalizada, outros que os classifiquem como subclasse atrelada ao poder, como conselheiros e consultores, papel que os intelectuais acabam fazendo quando se aproximam da política diária. Mas na sci-fi eles sempre aparecem como seres 
nobres desde Júlio Verne e seus seguidores (são figuras vigorosas e apaixonadas quando jovens e distraídos e sentimentais quando velhos)

Pela teoria marxista, a classe proletária seria o agente da revolução por estarem no ponto de vista que revela a verdade, o ponto de vista da produção. "Somente aqueles que sabem quão calamitosas são as coisas realmente podem ser suficientemente livres de ilusões e de interesses para mudá-las”, sintetiza essa idéia o teórico inglês Terry Eagleton em seu livro After Theory (2003, p.136). Claro que entre as calamidades atuais está a ecológica, a qual os cientistas estão em posição privilegiada para apontarem. Mas eles estariam da mesma forma em um bom lugar para detectar o caos político e social?

O próprio Jameson aponta a atual aderência entre ciência e política na resenha do livro de Robinson: "É cada vez mais óbvio o fato que a pesquisa científica hoje em dia é ela mesma uma forma especializada de política institucional”. Ele ainda crava que é falsa a impressão no leitor da trilogia marciana que a obra intercala capítulos sobre ciência com outros sobre política, afinal, cada avanço científico em Marte “tem uma inevitável dimensão política”.

Robinson, porém, imagina em sua trilogia cientistas que apreendem as verdades econômicas, políticas e sociais tais como se elas fossem só visíveis pelo microscópio de seu laboratório. O exemplo maior é o triângulo Vlad, Ursula e Marina, criadores ao mesmo tempo do tratamento da longevidade e da eco-economia. Vlad faz uma defesa veemente de sua invenção econômica em debate com o conservador Antar durante o congresso para formular a constituinte marciana, com uma visão das mais pessimistas sobre o capitalismo e defendendo o poder para cooperativas, sindicatos e outras formas coletivas. Como Arkadi no início e Sax no desfecho da saga, Vlad representa um ponto de vista que, segundo o pensamento marxista, seria o do revolucionário, ou seja, o ângulo de visão que revela a verdade objetiva da sociedade.

Se a figura do cientista revolucionário surge como pouco crível em uma análise política, ela tem forte empatia com o público leitor de ficção científica. Porém, como diria Theodor Adorno em Notas de Literatura, a verdadeira arte é inverossímil, já que o verossímil só corrobora a sociedade de sua época. Como Jameson elogia a ruptura (“a nova estratégia discursiva”, cuja forma é a utopia), Adorno não perdoa na obra do inglês Aldous Huxley "essa infame continuidade" em que conclui seus livros, fetichizando o fetiche da tecnologia ("Aldous Huxley e a Utopia” em Prismas, livro de 1955).

O próprio Adorno, em seu livro Dialética do Esclarecimento (1985), aponta que o progresso da ciência aumentou as fórmulas e regras de probabilidade ao custo de renunciar ao sentido e ao pensamento. "Na atividade científica moderna, o preço das grandes invenções é a ruína progressiva da cultura teórica”, proclama.

Jameson prefere se afastar do lugar comum de colocar a ciência moderna no papel central na história das idéias. E afirma que a ciência, assim como o realismo literário, seriam subprodutos do processo de secularização da percepção e conhecimento da realidade, que resiste a escapar à compreensão humana (um dilema muito presente na personagem Sax: "Em teoria teríamos de sermos capazes de encontrar as razões sempre. Quando não podemos... bem, me sinto ultrajado. Às vezes, eu chamo... eu chamo isso 'A Grande Incógnita'”, explica para Nirgal porque quer responder a todos os porquês que seus alunos lançam em Zigoto).

Os cientistas, esses “portadores de futuro”, são os mocinhos da maioria dos livros de 
Robinson, contrastando com o estereótipo do monstro de avental tão comum nos laboratórios da ficção científica. A visão positiva do escritor foi um dos temas de entrevista para a revista Science Fiction Studies (FOOTE, 1994): “Ciência para mim é uma tentativa de solução, uma política utópica que não é autoconsciente, mas poderosa e uma fonte de esperança.”

Essa visão otimista dos cientistas é uma constante na tradição utópica. A hegemonia desses "seres racionais" sobre a sociedade é uma forma de utopia que tem sua origem no século 17, com Isaac Newton fascinando os pensadores. Fourier, por exemplo, se imaginou transportando as leis newtonianas para a sociologia.

Já nas primeiras obras de Saint-Simon, os cientistas ocupam um papel transcendental na sociedade, em uma casta superior a todas as outras. Para ele, o cientista era a força seminal da História. No topo da estrutura social, eles poderiam dar ordens racionais para cessar os conflitos sociais e atingir a felicidade terrestre.

O francês foi defensor da criação de um papado científico, com a convocatória de grandes concílios de mestres internacionais para guiar a humanidade - o que se assemelha aos congressos políticos e científicos promovidos por Robinson em sua trilogia de Marte.

Entretanto, no final da vida, Saint-Simon os destronou desse posto magnânimo. De paladinos heróicos passaram a simples seguidores, desbancados da alta administração da sociedade para viver de sinecuras (a versão moderna são as bolsas polpudas e os diversos prêmios à disposição deles).

Essa mudança de visão de Saint-Simon foi devido a que ele fora colocado de lado pela ciência oficial da Era Napoleônica, repleta de benesses assim como de burocracias e restrições. Nesse segundo momento, o pensador utópico equipara os cientistas aos empresários e trabalhadores no rótulo “industriais”, em uma visão, digamos, mais tecnológica do panorama.

A posição prestigiosa dos cientistas se reafirmou ao longo dos séculos desde o Iluminismo até chegar a ficção científica da transição do século 20 para o 21, da qual Robinson faz parte. Por isso, não é fora de lugar ele criar uma personagem como William Fort, o cientista que descobriu a cura do câncer, dono da corporação Práxis e que se transforma em um mecenas de Marte independente.

Essa imagem de ciência em estado puro antagoniza com a posição bem menos elevada que a classe científica real possui. Uma fala da personagem Arkadi Bogdanov exemplifica isso quando ainda no Ares tenta semear entre os colegas a idéia de criar uma nova sociedade: "Somos cientistas do século 21 em Marte mas, ao mesmo tempo, vivemos dentro de um sistema social do século 19, baseado em ideologias do século 17 (...) Temos de terraformar nós mesmos.” (1993, p. 89)

Mais adiante, a mesma personagem, em conversa com Sax, diverge da posição de darwinismo social do cientista. "A história é lamarquiana”, proclama, ressaltando que as pessoas fazem escolhas dentro de seu meio (Red Mars, página 88). Mas é um diálogo com o situacionista Frank que mostra seu perfil idealista, expansivo e provocativo às vésperas da revolução: "Pois levaremos uma vida humana, Frank. Trabalharemos para satisfazer nossas necessidades, e talvez terraformaremos um pouco mais. Cantaremos, dançaremos, passearemos ao sol e trabalharemos como loucos por curiosidade ou por comida” (1993, p.457).

Jameson, com sua aposta teórica nas potencialidades de uma utopia pós-moderna, também aponta que a mudança pode vir de onde menos se espera. Emprestando conceitos do filósofo francês 
Louis Marin e do crítico norte-americano Christopher Kendrick, Jameson afirma que qualquer futura teoria sobre reemergência do texto utópico deve levar em conta que essas articulações surgem de "uma caleidoscópica visão de uma classe sem projeto ou nação", ou seja, sem uma análise da situação e sem um alinhamento à estratégia política. Para Jameson, isso "caracteriza bem nossas próprias posições pós-Guerra Fria e pós-neoliberalismo”. Mas caracteriza também a tal classe científica, que se coloca sempre como internacional, sem ideologias ou alinhamentos.

Em sua profissão de fé utópica, Jameson diz que o que há de mais produtivo no texto utópico é "detectar até o mais fraco sinal positivo do passado e do futuro para uma bricolage e uma combinação deles e, dessa forma, produzir o que pareceria um quadro representacional.” (2005, p.29) 


\subsection{O tempo}

Um dos feitos científicos mais notáveis da obra é o tratamento para recuperar a memória dos 14 pioneiros que ainda vivem no ano de 2211, quase 200 anos após a chegada deles ao planeta. O esforço da equipe de Ursula, somado ao dos cientistas de Da Vinci e da novata Bao Shuyo, reativa com o auxílio da química (leia-se coquetel de pílulas) e da física (ondas eletromagnéticas) as reminiscências do épico e possibilita um flashback coletivo, uma recapitulação de tudo que aconteceu até ali, o que inclui, como vimos, a descoberta do assassino de John Boone, dando fim à trama detetivesca-psicológica dentro dos livros.

A rememoração dá brecha para uma redenção da civilização marciana criada pelo escritor. Ou como diria Benjamin (1985) em sua terceira tese sobre o conceito de história: "Somente a humanidade redimida poderá apropriar-se totalmente de seu passado. Isso quer dizer: somente para a humanidade redimida o passado é citável, em cada um de seus momentos”. Para o pensador alemão, o dia em que isso acontecer será o verdadeiro “juízo final”. Se levarmos em conta que a trilogia termina em uma paradisíaca cena de praia com várias gerações na areia e Ann pensando na famosa frase de Galileu após negar a tese do movimento da Terra em torno do Sol ("Mas ela se move”), o paralelismo com a tese benjaminiana é grande.

Mas a redenção tem uma feição fragmentária, afinal, o Marte utópico é um planeta de feudos multiculturais, em que cada região determina suas leis, crenças e hierarquias. Parece o cenário batizado por Zizek (2003) de "férias americanas da história", um universo liberal de tolerância em que os EUA se hospedaram até os atentados de 11 de setembro de 2001 jogá-los de volta à realidade mundial, demolindo suas torres. $\mathrm{O}$ autor esloveno conta que naquele momento a mídia anunciou o fim da "idade da ironia”, ou seja, não havia mais espaço para o deslize desconstrutivista pósmoderno do sentido. "Agora precisamos mais uma vez do compromisso firme e sem ambigüidade" era o mantra após o choque de realidade com as ações na capital financeira, Nova York, e na capital administrativa e militar, Washington (2003, p.50-1).

Mas o baque logo após a virada de século deu lugar novamente à anterior atitude pósmoderna de escamotear a realidade por meio de seus mecanismos de fragmentação. O pósmodernismo, no auge à época da escritura da trilogia marciana de Robinson, segue sendo um dispositivo bem prático de dissimulação, um bom subterfúgio para deixar o real apenas como uma reminiscência.

O crucial papel da memória também é apontado por Georg Lukács em Teoria do Romance (2000), quando fala que o embate da ação da narrativa se dá contra o poder do tempo e faz emergir “as experiências temporais autenticamente épicas: a esperança e a reminiscência”. Na trilogia de Robinson, tão extensa e com um tema tão épico como a colonização humana do universo, os dois capítulos finais se encarregam de recuperar a fé no futuro e a certeza do passado.

E é na transformação de Ann que isso fica transparente. De sua fixação mórbida pela morte, pelo suicídio, pela matéria inanimada e pelo planeta mineral, a personagem encena nas últimas páginas uma luta pela vida, quando o mal súbito que vitimou tantos contemporâneos seus a ataca. Sua opção pela própria vida é também a opção pela vida no planeta vermelho, cooptando por uma utopia biológica contra a utopia geológica que defendeu durante dois séculos. Com isso, ela ultrapassa o estágio existencialista a la Heiddeger em que o futuro é visto como "a promessa de mortalidade”, e dá ao futuro o sinal positivo típico dos utópicos. 
Pois, Ann parece se aproximar nessa cena ao estágio que Lukács descreve como a superação da relação sujeito-objeto: "O sujeito só pode ultrapassar o dualismo da interioridade e da exterioridade quando percebe a unidade de toda a vida (...) na corrente vital do seu passado, resumida na reminiscência.” Já a personagem Maya, perturbada pelos déjà vu, jamais vu, presque $v u$ e por seu passado de mulher manipuladora e triplamente viúva, prefere continuar sem passado, com a impressão de felicidade que a alienação concede.

O poder do tempo, citado por Lukács (2000), é minado na ficção de Robinson pelo tratamento de longevidade, que como Jameson frisou, cria uma "analogia entre o tempo histórico e a extensão de leitura do romance”. O tempo de vida dos pioneiros sobreviventes adota quase um ritmo geológico (ou areológico, já que falamos de Marte). As existências deles se alongam, enquanto as transformações na superfície marciana se aceleram como se tivessem apertado o botão fast forward. Ou seja, tempo biológico é estendido, e tempo geológico, acelerado ao máximo. Tudo para que eles coincidam, as mudanças aconteçam e "para proporcionar uma experiência da história impossível dentro dos limites biológicos”, como salienta Jameson. (2005, p.188).

Suvin (1984) afirma que isso funciona se houver um fundo científico a ligar a realidade do leitor com a ficção do autor: “Os protagonistas poderão triunfar ou fracassar em seus objetivos, mas no seu contrato básico feito com o leitor, nas leis físicas de ambos os mundos, nada garante nenhum desses resultados.” A expectativa de vida dos homens ter quase duplicado nos últimos séculos dá essa perspectiva de prolongamento da vida humana, afinal, o próprio Robinson sabe que o tratamento é uma artimanha em trama. "O tipo de pílula mágica que eu descrevo em Red Mars, que duplica instantaneamente a longevidade, é algo que não vai acontecer, mas a elevação gradual do tempo de vida é claramente possível”, afirmou para a revista de tecnologia Wired, em entrevista publicada em julho de 2007 (KEIM, 2007).

O novum faz dos homens não visitantes de Marte, mas agentes de longo prazo em sua transformação, apesar do épico marciano repetir a idéia de que é mais fácil mudar o que é exterior ao homem do que o que lhe é interno. Mas esse achado é que causa o estranhamento narrativo da trama: os líderes de uma utopia no século 23 são literalmente pessoas nascidas e moldadas no século 20.

Suvin classifica também uma subdivisão que pode ser chamada de "utopia médica", que abarcaria temas como a busca da imortalidade, da juventude eterna e da tecnologia prolongando ao máximo o metabolismo humano. Esse desejo é como a complementação ideal para a colonização do futuro que o capitalismo imagina empreender - seguindo a lógica egoísta: de que vale o futuro estar garantido se não vou estar lá ou vou estar em más condições para desfrutá-lo?

O professor croata comenta que "a forte tendência a uma extrapolação temporal, inerente a uma vida assentada em uma economia capitalista, cujos salários, lucros e ideais progressistas são esperados sempre no futuro" é mais um facilitador na hora de escrever ou ler relatos que escapam da limitação narrativa. "Mas a variável mais plausível em sua manipulação é o tempo, já que um relato situado no futuro de imediato alivia toda a necessidade de plausibilidade empírica”, escreve o teórico (1984)

Opinião semelhante tem Raymond Williams, que escreveu no livro de The Long Revolution que o futuro é um mero recurso "que elimina a tensão usual entre o padrão eleito e a observação moral.” (p. 307) Por esse mesmo raciocínio, o gênero fantasia cria efeito similar com um tempo 
mítico, seja ele passado, presente ou futuro (com isso, se vê que o chavão que afirma que a literatura dá "asas à imaginação" na verdade está corroborando um sistema que vive na ilusão que pode controlar os tempos com suas estatísticas, investimentos e tecnologias, mas que nos momentos de crise como a recessão que se avizinha a partir do final de 2008 mostra que o presente pode atropelar o futuro previsto e jogar o mundo em um cenário que se acreditava coisa do passado: uma crise global como a de 1929).

Em entrevista em 1996 para a Locus (1996), tradicional revista de informações sobre sci-fi com sede em Oakland (EUA) e fundada no ano de 1968, Robinson conta que o processo de tornar a atmosfera e o solo marcianos aptos à vida foi o mais veloz entre os sugeridos pelos especialistas no assunto que ele consultou - suas personagens usam desde moinhos de vento com algas até lentes na órbita, reatores nucleares, buracos de 18 quilômetros de profundidade até o manto do planeta. Na conta de calorias, entram as revoluções e a energia desprendida de seus armamentos, que acabam contribuindo também (os métodos agressivos de intervenção humana com grandes efeitos colaterais depois são renegados em obras posteriores). "Na minha trilogia marciana, a terraformação é rápida, levando 300 anos. Eu utilizei de tudo, de forma a que fosse a mais acelerada fisicamente possível, como se tudo desse certo: os efeitos sinergéticos funcionando com todos os métodos que me foram sugeridos. Eu acatei todas as sugestões que ouvi e ainda criei umas por mim mesmo (...) Se eu fosse montar na escala mais realística possível, levaria 5.000 anos.”

A prioridade é produzir um planeta habitável, para depois dar vazão às utopias. O tempo linear vira o espaço da produção. E no capitalismo, o tempo termina por equivaler a dinheiro. A aceleração de Robinson já se dá de princípio na data em que começa o empreendimento humano em Marte, mas esse é um dos riscos de escrever no gênero "futuro próximo", ou seja, a descrição de um porvir que entra no próprio tempo biográfico do autor (Robinson já expressou vontade de alterar seu romance The Gold Coast, escrito em 1986, porque nele a URSS aparece como os bad guys, mas o pedido foi recusado pelo editor. Ele mudaria o rival para nações de porte médio como inimigos dos EUA, o que é mais condizente com o momento atual, mas essa lógica também pode caducar em poucos anos caso a China, por exemplo, continue a crescer no mesmo ritmo atual e faça frente à superpotência, o que retomaria a lógica de dois pólos).

A corrida espacial desacelerou com o fim da então concorrente URSS e os vários fracassos e explosões com os ônibus espaciais norte-americanos. Poder-se-ia argumentar também que as guerras contra países islâmicos, como Afeganistão e Iraque, também mudaram o foco dos EUA. Esse argumento é menos convincente, já que na mesma época da Guerra do Vietnã, Washington realizou diversas viagens à Lua simultaneamente (entre 1969-1972, os EUA enviaram 12 homens ao satélite natural).

Em janeiro de 2004, com miras na sua reeleição, George W. Bush anunciou mais verba para a Nasa (0,5 \% do orçamento norte-americano vai para a agência), planos para uma base permanente na lua e uma missão tripulada para Marte. Os prazos são longos e evasivos, com a volta das naves tripuladas em direção ao satélite natural até o ano de 2020. Se as viagens lunares, cuja duração é de três dias, levarão tanto tempo para serem retomadas, imagine-se quando se dará a ida a Marte, que leva seis meses no espaço (como mostra a trilogia) - no livro de Robinson, ela está marcada para 2026.

Apesar da persistência do pensamento ao longo dos últimos cinco séculos, o texto utópico tem prazo de validade curto, como Terry Eagleton aponta - a concepção cai como uma luva para a obra de Robinson, ainda com forte influência do período de Guerra Fria. “A Utopia é a mais efêmera das formas literárias, construindo seus mundos ideais simplesmente para promover alguma obsessão 
local do presente”, escreveu em seu livro Figures of Dissent (2003b, p.29).

O ficcionista confessa, na mesma entrevista para a revista Locus, que queria fazer "um romance clássico, sobre um grupo de personagens, indo através de sua vida, do começo ao fim. Por isso, existe uma tão acentuada noção de conclusão nos três últimos capítulos para as três personagens principais. Eu não posso imaginar um fechamento mais total que aquele.”

Esse tratamento do coletivo é uma das características épicas da obra. Por sua extensão em páginas, em tempo narrativo, em personagens principais e em espaço da ação, o livro mostra uma envergadura típica de um épico. Outro ponto em que a trilogia se associa com o gênero é na relação com a memória. No final de Blue Mars, os acontecimentos ocorridos estão seriamente ameaçados seja pela amnésia dos pioneiros, seja pela visão iconoclasta dos jovens (Zo dá uma versão da história marciana que apequena os fundadores) ou pelos possíveis desdobramentos futuros (a política isolacionista acaba causando uma invasão terráquea, depois controlada).

Mas esse cenário é contornado quando os sobreviventes dos "Primeiros Cem” se submetem ao tratamento para recuperar a memória, o que devolve os contornos heróicos ao itinerário até ali. Jameson vê nesse episódio uma metonímia da estrutura de toda a trilogia: "O problema de memória dos sobreviventes e a relação da memória com a estrutura do cérebro são uma espécie de projeção decorativa do dispositivo estrutural ou narrativo.”

Como Benjamin lembra no ensaio "O Narrador”, a deusa da reminiscência, Mnemosyne, era para os gregos a musa da poesia épica. "A reminiscência funda a cadeia da tradição, que transmite os acontecimentos de geração em geração. Ela corresponde à musa épica no sentido mais amplo. Ela inclui todas as variedades da forma épica”, escreve nesse texto o pensador alemão. Essa recuperação do passado muda de chave pelas mãos de Jameson quando ele pede a recuperação do futuro (tanto do porvir imaginado no passado como o projetado na atualidade).

O aspecto coletivo, contudo, também tem sua face menos épica e mais burocrática. Esta aparece nos episódios em que o foco é a normatização da mudança. Há ao longo da trilogia pelo menos seis congressos relatados, todos mistos de encontros acadêmicos com fóruns sociais ou econômicos, divididos por painéis, temas e mesas. Quatro são puramente políticos (e há na trilogia uma revalorização da política), como a reunião após a grande tempestade, o congresso da resistência em Dorsa Brevia, a constituinte pós-revolução em Pavonis Mons e a cúpula com os terráqueos na Suíça. Os outros dois são congressos científicos, um em Green Mars, o último em Blue Mars, e a questão principal é a terraformação.

Mas o mais importante é o “A New Constitution”, em que as discussões e votações são descritas em cerca de 50 páginas. Em entrevista para a revista online Sci-Fi Universe, Robinson admite que temia uma má recepção do longo capítulo em que mostra como a constituição foi feita. "No capítulo constitucional, eu senti que estava me arriscando ao escrever sobre política tão longamente, mas, se você vai fazer isso, tem de colocar todas as cartas na mesa e ser muito explícito sobre como a sociedade funciona. Dessa forma, os leitores não precisam ficar intuindo como as coisas são. Talvez seja um capítulo tedioso, talvez eu o tenha feito interessante, é um desafio. Não há muitos romances que concedem um grande capítulo para falar sobre como uma Constituição foi escrita.” (BABCOCK, 1996). Jameson aponta que a visão utópica da reorganização burocrática remonta a Jean-Jacques Rousseau e Henri de Saint-Simon, mas que as constituições ficcionais ficaram por muito tempo fora de moda até o texto marciano de Robinson. 
Para o pensador alemão Carl Schmitt, o poder constituinte é um poder divino, afinal, é o poder da criação. Por isso, a participação de Hiroko no congresso de Dorsa Brevia, fazendo uma celebração mística do documento que saiu ao fim de dias de reunião discutindo um futuro e hipotético governo independente de Marte, parece uma prova da associação de Schmitt entre os constituintes e os deuses.

É também a inauguração de um novo tempo. Um tempo com um calendário de anos que causa estranhamento, como M-40 (que é o ano cristão de 2107) ou M-52 (2127), anos marcados a partir da chegada humana em Marte. Também é estranho que as estações do ano não tenham nomes sonoros e sejam na verdade equações que medem o ângulo de incidência do sol, como Ls = 0 - 90 . Outra particularidade marciana é que seus dias têm 39,5 minutos a mais que a jornada terráquea, mas se convencionou no romance que à meia-noite os relógios param e esperam esse tempo para dar a sensação de simultaneidade com a Terra. É nesse lapso de tempo (o tal Martian Time-Slip, título de livro de Philip K. Dick), quando justamente vários fatos se desencadeiam, como o lapso freudiano é quando se revela a verdade que estava no inconsciente.

Marte também possibilita uma aceleração ainda maior pelas seguidas revoluções que pelas questões astronômicas. Como escreveu Benjamin em suas teses, as revoluções e seus novos calendários (como o criado após a Revolução Francesa) funcionam como um acelerador histórico. É perturbador chegar ao final de uma saga de quase 2.000 páginas, com muitos trechos em que a ação pára para descrições científicas bem ao gosto naturalista, e ainda constatar que os mais de 200 anos ali narrados parecem imprimir uma velocidade tremenda em relação ao ritmo arrastado da humanidade de agora. Na verdade, essa impressão deixada pela trilogia escancara a estagnação e a mentalidade atuais em que qualquer mudança é vista como uma perturbação, uma interrupção, uma ruptura (todas essas palavras são possíveis traduções para a inglesa disruption). Ou o melhor seria adotar a imagem invertida de Benjamin em que a revolução é o "freio de emergência" para o “continuum da história”, que é a inércia humana?

Zizek atualizou o insight benjaminiano ao remeter ao sistema atual para que nada novo surja. “À parte uma administração econômica anêmica, a principal função do centro liberal-democrático é garantir que nada aconteça realmente na política: a liberal-democracia é parte do não-evento”, cravou em Bem-Vindo ao Deserto do Real! (2003, p.174).

Por sua vez, Jameson lembra em “The Future As Disruption” que a Utopia é caracterizada pelo confronto de duas temporalidades: “o gesto inaugural em oposição ao cotidiano utópico após o fim da história”. Robinson montou um enredo em que, ao final, as personagens mais ativas acabam se dando mal, enquanto as mais corriqueiras e pragmáticas acabam ao final tocando o dia-a-dia da revolução.

É emblemática a trajetória das figuras carismáticas como John Boone, Arkadi Bogdanov e Nirgal - os dois primeiros morrem logo no primeiro volume, o terceiro opta, como vimos, pelo escapismo após surgir como um possível líder arregimentador. Todos fazem discursos inflamados, propõe idéias novas e tentam unir a população. Contudo, a utopia de Robinson não pode ter um "grande pai" a ditar as regras, um "grande timoneiro" a guiar um povo, um "grande irmão" a estar de olho em tudo. Da mesma forma as personagens manipuladoras e maquiavélicas também se dão mal. O maior exemplo é Frank Chalmers, mas Maya e Jackie também entram nesse hall. O poder não está mais na esfera das negociatas, conchavos e golpes palacianos - ele está nas ruas e nos congressos. 
Isso se alinha com a opinião de Jameson de que a idéia de revolução é especialmente problemática "em uma época sem agência, mas em que o poder é uma rede cibernética”. Na trama de Robinson, quem mais agita acaba enredado, enquanto os mais cientes dos nós a desatar põem em ação a Utopia. É o embate entre os partidários do gesto inaugural contra os da regulamentação do sonho político. Nadia é quem narra as duas revoluções de um ponto de vista distante, mas é ela também que descreve o congresso da resistência em Dorsa Brevia, dessa vez bem próxima das discussões. No congresso constituinte após a revolução de 2127 é a vez do pragmático Art, par de Nadia, dar o viés do que é narrado.

Nesse último episódio, o enfoque é na rede de interesses, na diferença de opiniões (chama-se até o representante das derrotadas corporações), na contemporização dos conflitos, da aceitação da fragmentação típica do pós-modernismo, da busca de um acordo comum entre as posições. A defesa de uma espécie de federalismo seria mais condizente com o problema de criar uma utopia em épocas cibernéticas (com alta tecnologia e globalização), que obrigatoriamente, segundo Jameson, obedeceria a uma formatação diferente de suas edições anteriores, de cunho campestre e industrial.

O que a trilogia aponta são utopias sincronizadas em mesmo cenário, todas utopias estáticas internamente, o que pode aumentar ainda mais a sensação que se chegou ao "fim da História". Afinal, só há sincronia. Não há diacronia, ou seja, não se pode ver mudança com a passagem do tempo. O movimento só se dá no espaço, se dá no deslocamento de uma utopia para outra, o que pode significar trocar um local de caçadores pré-históricos e, afastando-se milênios em poucos quilômetros, ir para uma cidadela tecnológica com humanos que têm aspecto marciano.

No texto “Uma Utopia Moderna”, H.G. Wells diferenciou entre as utopias estáticas e dinâmicas. A pergunta por trás é: há um mundo perfeito ou a busca literária e política seria atrás de algo melhor? Há quem acredite na sociedade ideal: tanto Fourier como Marx projetavam que emergeria do último conflito de sistema e classes o cessar de toda luta de poder entre os homens.

Há outros que preferem a segunda opção. Um deles é Yevgeni Zamiatin, autor do romance futurista My (Nós), escrito em 1920, tido na URSS como panfleto anti-soviético por mostrar uma sociedade opressiva e obra que influenciou George Orwell e Aldous Huxley. "As verdades de hoje são os erros de amanhã: não existe número final”, foi a máxima de Zamiatin, que se considerava mais revolucionário do que os bolcheviques e morreu exilado em Paris em 1937, desprezado pelas autoridades stalinistas e pela comunidade russa conservadora que morava na França.

O final paradisíaco da trilogia de Robinson sugere uma opção pela utopia estática, apesar do cardápio vasto delas. É uma pluralidade estanque, diferente das versões antigas, como o imaginário tradicional hinduísta de sucessão quase infinita de numerosos mundos. Na trilogia, o que há é a cronologia humana e seus calendários passados e futuros expostos e imóveis para a livre escolha.

No multiculturalismo que acaba formatando principalmente o último volume, o futuro é um presente com mais caminhos opcionais, que vão além do horizonte atual. Robinson leva essa lógica ao extremo como se toda a História estivesse à disposição. O catálogo inclui até o tal grupo de caçadores do terceiro livro, representando um tipo de sociedade que extravasa os instintos agressivos do homem, diametralmente o oposto da sociedade de corte e seu gestual contido (também prevista pela utopia).

Na cena final da trilogia, Art e Nadia estão na praia cuidando dos netos e fica-se sabendo que a filha do casal, Nikki, "empreendeu uma viagem com os selvagens das Montanhas Hellespontus". 
Percebe-se uma similaridade com os parques temáticos e resorts de aventura que tentam recuperar como show o passado de tempos bruscos, seja um passeio em "barco pirata" pelo Caribe ou um torneio medieval em um bar (uma violência domesticada, sem o sangue das guerras e revoluções).

De partida, as energias libidinais e destrutivas do homem representam uma irracionalidade que não combina com o sonho meditado de cooperação entre os homens para se chegar à felicidade. As teorias de Sigmund Freud, que podem ser classificadas de distópicas, mostraram como essa busca é mais complexa e ultrapassa a dimensão material (FREUD, 1961) (o trabalhador deixar de ser mercadoria não basta). Já Friedrich Engels apontava que é impossível que formas primitivas resolvam conflitos em sociedades mais desenvolvidas. Se seguirmos as indicações acima, nem o cérebro nem o fígado vão salvar a humanidade. 


\subsection{O espaço}

Além dos deslocamentos no tempo, há uma clara transposição de lugar, projetando para Marte os desejos que seriam direcionados para a Terra, em uma patente metáfora entre os dois astros, como o futuro pintado na ficção científica sempre uma metáfora para o presente.

Contudo a Terra propriamente registrada na trilogia cumpre uma espécie de futuro distópico, ficando relegada a um cenário catastrófico de continuidade e contabilizando os prejuízos de sua vocação capitalista - no final da trama se prefigura uma salvação da Terra por parte de Marte, pelo menos com o paliativo de permitir uma maior migração de terráqueos ao novo planeta azul.

O espelhismo conforma a relação entre Terra e Marte na ficção de Robinson. A personagem Nirgal explicita esse procedimento de Robinson ao abrir seu discurso na chegada à Terra com a frase: "Marte é um espelho em que a Terra contempla sua própria essência." O novo planeta habitado seria uma versão purificada, segundo o jovem marciano. Essa mudança de consciência provocada pelo distanciamento da Terra é figurada no começo da trilogia como uma insanidade provocada pelo planeta, principalmente na visão do pragmático Frank Chalmers.

O autor monta ainda um espelhismo reverso, invertendo as características, até mesmo as físicas. Um exemplo, o aquecimento da atmosfera e o conseqüente derretimento polar é positivo em Marte, e negativo na Terra. O hemisfério das águas é o sul na Terra, e o norte em Marte. Mas a inversão mais inventiva é o movimento conservacionista ser vermelho (mineral) contra a versão verde (biológica) dos terráqueos.

Outra inversão é o papel da multidão nos dois planetas. Na Terra, ela é uma massa de manobra, um aglomerado bovino e uma estatística superpovoada - a única revolta registrada é pelo tratamento de longevidade, ou seja, protesto por mais daquela vida, mas não uma vida melhor. Já em Marte, o povo tem um papel político importante, forçando as tropas das metanacs a recuar após ocuparem as ruas durante as revoluções de veludo ou, como a personagem Hiroko sugere, de aerosol.

A Terra também serve como termo de comparação para mostrar o gigantismo e a vastidão da geografia marciana - nisso há um quê de Rabelais. Dessa forma, uma inundação é descrita como “cem vezes maior que o Amazonas”. Já um canyon é dimensionado "na escala de um SuperHimalaia”. Em entrevista a revista Locus (1996), o escritor fala de sua opção pela ficção científica ao ar livre: "Das mais diversas maneiras, a existência em nosso século 20 é absurdamente nãofísica. E vivemos dentro de caixas. É uma das imagens da ficção científica: um mundo de cérebros dentro de garrafas.”

O elogio à natureza inclui a paisagem mineral que os pioneiros vislumbram ao chegar. Estranho para o ponto de vista comum, a personagem Ann reverencia o cenário áspero e pétreo, como alguns paraísos pretéritos, feitos de gemas como ônix, jaspe, safira, esmeralda ou topázio.

Já os partidários de um Marte verde compartilham da imagem do paraíso como um jardim, a representação de uma natureza perfeita, esculpida pela mão do homem. No caso da trilogia, essa seria uma utopia de traços edênicos (pelo lado passadista, ingênuo e idílico) misturados com componentes prometéicos, principalmente o uso da tecnologia e do conhecimento para criar espécies resistentes ao frio e aridez local. 
Robinson se viu beneficiado pela enxurrada de informação após a chegada em 1976 das primeiras imagens feitas pela nave Viking, que pousou em Marte naquele ano. $\mathrm{O}$ autor teve a sua disposição imagens em três dimensões da superfície de buracos, crateras e rochas. Consultou o responsável pelo mapeamento marciano do Instituto Smithsonian Aeroespacial, além de um expert britânico em terraformação.

Mas a pessoa mais consultada foi Christopher McKay, planetologista da Nasa, que publicou artigo na revista especializada Nature elevando o tema terraformação a uma questão importante dentro da pauta científica da atualidade, reforçada ainda mais com o aquecimento global ganhando destaque na mídia após o governo britânico divulgar relatório em 2006 sobre a potencialidade de prejuízo das empresas e a ameaça de instabilidade econômica que as mudanças climáticas irão causar. A terraformação já foi tema de vários livros de ficção (Arthur C. Clarke e Robert A. Heinlein utilizaram o tema) e também de publicações de divulgação científica (Carl Sagan, especialmente).

Se a colonização de outros astros está nos livros e nos planos futuros da humanidade, ou o homem se adapta aos ambientes inóspitos, por meio da engenharia genética ou da automatização de parte do corpo (cyborgs), ou terá de praticar algum nível de terraformação dos planetas escolhidos. O imaginário das incursões humanas pelo universo começou muito decalcada na experiência do expansionismo europeu, principalmente no Império Britânico durante a virada do século 19 ao 20. Depois foi a fase do caminho contrário, o temor inglês de ver sua ilha invadida, pelos alemães ou franceses, fez surgir uma onda livresca de invasões alienígenas. Os EUA seguiram essa onda, mas mirando no "perigo amarelo" (Japão) na Segunda Guerra Mundial e no “perigo vermelho” (URSS) durante a Guerra Fria. Passados esses períodos e com a possibilidade de outras formas de vida na Via Láctea descartada pelas recentes descobertas astronômicas, a literatura norte-americana intensificou seu lado colonizador. A trilogia de Robinson é um exemplo dessa tendência, e, mesmo ela, carrega a idéia anterior de imperialismo, associando a Terra à pátria-mãe (Inglaterra) e Marte como uma colônia que se torna independente e influente (EUA).

Robinson só não pôde utilizar as informações e imagens do rover Pathfinder, que começou a percorrer a superfície do planeta em 1997, ano seguinte da publicação de Blue Mars - de qualquer forma, Robinson estava a anos-luz em termos de dados que seu conterrâneo Percival Lowell (18551916), que escreveu em 1895 o livro Marte sobre a civilização marciana que irrigou todo o planeta. Ele elevava à ficção a "descoberta” do astrônomo italiano Giovanni Schiaparelli em 1877 de canais na superfície. Hoje a suposição é que esses canali foram criados pela ação das águas em um passado remoto do planeta. Mesmo com essas atualizações, Robinson preferiu colocar em seu relato o tal pequeno povo vermelho, recorrente até a década de 50 nos livros sobre Marte (depois o tema da colonização o superou em popularidade, afinal, as teses de vida em Marte iam sendo derrubadas).

Fora o conhecimento de segunda mão, o literato fez duas viagens que o ajudaram a compor o cenário. Durante o processo de criação, ele foi ao Meteor Crater, imensa cratera perto de Flagstaff (Arizona) para colecionar impressões, imagens e se inspirar com a paisagem mais marciana que terráquea de ali. A literatura norte-americana sempre lidou com a idéia de vastidão de sua natureza, seja de suas florestas ou de seus desertos. E criou em torno dela uma série de seres simbólicos, bestiários e fábulas populares. Por exemplo, o Grande Homem e Paul Bunyan são representações do homem devastador (ou empreendedor, na versão capitalista).

A outra visita de Robinson aconteceu um ano após a publicação de Blue Mars: a convite de um departamento do governo dos EUA ele ficou seis semanas na Antártida com a encomenda de 
escrever uma novela ambientada por lá, o que ocorreu logo depois. Mas a passagem pelo Pólo Sul também teve reflexos na trilogia: para uma segunda impressão dos livros, ele acrescentou algumas idéias e sensações que vivenciou no frio extremo para dar mais verdade ao relato do igualmente gelado Marte.

Os dez anos de pesquisa, as milhares de informações novas e as consultas aos mais variados especialistas, até na matéria ecopoiesis (espécie de engenharia planetária com objetivo de criação de um ecossistema sustentável em um lugar sem vida), deram à trilogia um realismo quase fotográfico das paisagens e dos ambientes de um lugar onde o homem nunca esteve.

Contudo o grau de detalhamento que Robinson desfila nas centenas de páginas dividiu a crítica. Arthur C. Clarke, autor do clássico 2001, Uma Odisséia no Espaço, ficou admirado com a riqueza. "O melhor romance jamais escrito sobre a colonização de Marte. Ele deveria ser leitura obrigatória para os colonizadores do próximo século”, disse o escritor inglês quando da publicação. Já parte das revistas especializadas não gostou da extensão e do recurso naturalista de parar a ação para descrever paisagens e processos (como o de fabricação do tijolo ideal para Marte).

Esse revestimento realista dá a impressão de um futuro plausível - uma noção que o autor voltou do futuro para relatar aquilo, a idéia que o futuro pode estar na imaginação profética desse escritor de ficção científica.

E se acumulam as descrições sobre a composição das rochas, sobre como se dá o impacto de um meteoro, sobre o escoamento do degelo da calota polar e sobre o crescimento de formas de vida na superfície, sejam liquens cor-de-rosa ou plantas de folhas peludas. Fora os diversos deslocamentos das personagens, que descrevem todos os quadrantes do planeta, começando pela primeira viagem dos geólogos, logo após a chegada, para encontrar água no pólo até o cruzeiro marítimo de Sax e Ann 200 anos depois. Esse esforço mostra, como Adorno escreveu, que toda a obra de arte é um tour de force - e a superfície de Marte se mostra tão resistente como a sociedade humana, mas as duas, ao final, se revolucionam pela vontade do escritor.

Robinson usou e abusou do material que recolheu na pesquisa. Uma passagem exemplar são as viagens interplanetárias entre a Terra e Marte, seja a pioneira no Ares com os primeiros colonos, seja a de Art em Green Mars, descrevendo o ambiente na base de lançamento de Cabo Canaveral. O nível de informação, que vai do combustível utilizado até as sensações físicas em cada compartimento da nave, cria a impressão que vai ser dessa maneira que o homem se deslocará em seu expansionismo espacial.

Essa preocupação realista na ambientação extremada contrasta com a solução fabulosa de o protagonista dormir e acordar no futuro, como nos clássicos utópicos da sci-fi do século 19 Looking Backward (1888), de Edward Bellamy, e News From Nowhere (1890), de William Morris. Ou entrar em máquinas do tempo ou câmaras criogênicas. Para Robinson, não pode ser tão fácil assim chegar a uma sociedade ideal, até um tratamento geriátrico ele estabeleceu para ganhar tempo para conquistar o espaço.

E essa é uma das razões porque o romance se estende por dezenas de centenas de páginas em três volumes até chegar a sua utopia federalista - para um final distópico, com uma compensação no toque de esperança mística, bastaria ficar no primeiro tomo da trilogia, com o fecho dos revolucionários derrotados chegando ao refúgio de Hiroko. O final feliz minimamente crível para nossa época em que reina a inanição requer idas e vindas, vitórias e derrotas, para mostrar que a 
história se move, que pode tomar outros rumos e que existem outras forças fora a inércia.

Na dialética entre being e becoming, há a clara opção pela transformação, atravancada, por vezes reformista, por vezes revolucionária, mas, de toda forma, uma aposta de futuro próxima a de Ernst Bloch. "Somente ao se abandonar o conceito fechado e imóvel do ser surge a real dimensão da esperança. O mundo está, antes, repleto de disposição para algo, tendência para algo, e o algo assim intencionado significa a plenitude do que é intencionado”, afirma o alemão em $O$ Princípio Esperança (2005, p.28).

Essa energia para a mudança já aparece no deslocamento inicial dos pioneiros, mas só se realiza plenamente depois de vencidos obstáculos geográficos e humanos, respectivamente pela terraformação e a independência de Marte. "O trabalho que faz a história avançar, sim, já há muito a fez avançar, conduz para a causa que tem possibilidade de ser boa, não como abismo, mas como montanha para o futuro. Os homens, assim como o mundo, carregam dentro de si a quantidade suficiente de futuro bom; nenhum plano é propriamente bom se não contiver essa fé basilar”, é o fecho que Bloch dá ao primeiro volume de O Princípio Esperança (2005, p.433).

A imagem do abismo e da montanha vem a calhar porque a superfície e a atmosfera de Marte impõem às personagens um desafio. Robinson pingou vários subplots na trilogia com apuros climáticos a la Julio Verne e suas aventuras em cavernas, balões e fenômenos meteorológicos. O dirigível de Nadia e Arkadi arrastado pela tempestade, Phyllis e Sax caindo em um poço de gelo e neve, ou Ann aproveitando uma avalanche para tentar mais um suicídio frustrado são alguns exemplos. Em todos esses casos (como em vários outros), o suspense criado em torno da possibilidade da força da natureza destruir o homem termina com as personagens se safando por pouco - a exceção, que confirma a regra, como já mencionado, é o episódio de Frank sendo engolido por uma onda durante fuga após a revolução de 2061. O revelador é que essas narrações, no final, servem apenas para mostrar como o planeta é hostil à presença humana, sem conseqüências para o desenrolar da linha-mestra do enredo, ou seja, são plots que só reforçam o que as descrições já disseram.

Até o final do século 19, as excursões utópicas tinham lugar em lugares extremos do globo terráqueo, como o Pacífico Sul. Quando o homem pisou até nos pólos ártico e antártico, a imaginação teve que migrar para fora da atmosfera para achar um lugar onde as quimeras se realizassem. No espaço sideral, o local preferido foi Marte, porque, à distancia, se assemelhava com a Terra (pólos com gelo, presença de nuvens etc.), em tons mais vermelhos.

Não por nada, John Boone parece Cristóvão Colombo ao imaginar um paraíso a ser construído na terra avistada. O trabalho de terraformar Marte desviaria o instinto agressivo dos homens para a natureza inóspita do lugar, remetendo a uma tese recorrente. "A histórica substituição do homem pela natureza como objeto de agressão, que com tanta força remete a Marx e a Freud, alimentou a crença otimista de Saint-Simon de que, com o tempo, não só será viável o progresso intelectual, se não também o progresso moral”, escreveram Frank e Fritzie Manuel no terceiro volume de seu livro sobre a utopia no Ocidente (1984, p.100).

Na idéia sansimoniana de exploração ilimitada da natureza, a luta intestina de classes e países seria deslocada para domar o mundo mineral e vegetal e explorá-los para o progresso humano, algo muito presente no intuito inicial da colonização de Marte contada por Robinson (uma visão polêmica do autor, afinal, a terraformação é uma ação muito agressiva e arriscada). Nessa ação de mudança total no cenário, os cientistas e os capitalistas têm papel primordial. "Na sociedade 
científica industrial, os impulsos básicos se orientariam em direção ao mundo dos objetos. Os cientistas estavam descobrindo as mais profundas verdades da natureza, e o industrial estava domando as forças refratárias da natureza (...) A direção dos homens da nova sociedade não era senão um fenômeno auxiliar de exploração da natureza, tanto no âmbito temporal como no espiritual”, escrevem o casal sobre as teorias de Saint-Simon e seus seguidores (1984, p.101).

Robinson sabe do dilema bem lukacsiano entre o narrar e o descrever e fez sua opção como mostra para a revista The Zone em entrevista (LAWIE, 2002): “Acho que o velho estilo da ficção científica, no qual era permitido parar a narração e explicar uma tonelada de coisas é uma oportunidade tanto quanto um problema estético. Se usar de forma adequada, você passa um monte de informação (incluindo a ideológica) que a ficção científica moderna, fluida, sofisticada e convencional não consegue te dar. Por exemplo, em meus livros sobre Marte, eu fiquei muito feliz de voltar a essa metodologia e dizer: 'Se é interessante, não importa que seja uma massaroca expositiva.’ É muito pós-moderno na idéia que qualquer coisa é potencialmente uma história (...) você pode pensar que é uma esquisita oportunidade pós-modernista de fazer algo que não seja só criar cenas de ação.”

Ou seja, o manual técnico de instruções de uma geringonça ou o tratado de climatologia ou o manifesto político são outros estilos literários a se juntarem na bricolage de Robinson. Por essas e outras razões, a trilogia deixa uma sensação de artefato, pelas constantes citações, referências, pela clara montagem das personagens, pela invenção de cidades, fatos e mapas e pela linha do enredo, que é fragmentada pela mudança constante de foco, lugar e estilo. Mas também o acúmulo de informação e a técnica realista dão a impressão que o autor veio do futuro para relatar o que vai ocorrer.

Quando se atravessa os longos trechos descritivos da trilogia, percebe-se que Robinson cria uma oscilação que vai do divertimento à exasperação, da credibilidade ao desdém. Enquanto a descrição das paisagens tende a fazer o leitor saltar páginas, quando o assunto são as cidades imaginadas por Robinson há um encantamento. 


\subsection{As cidades}

Os relatos das cidades marcianas obedecem, por um lado, a disneyficação dos lugares - há aldeias caiadas como nas ilhas gregas, alamedas à parisiense e prédios espelhados à moda norteamericana. Por outro lado, Robinson também inventou uma arquitetura bogdanovista, ou seja, projetos que unam um estilo leve e encurvado com a ideologia de uma função social progressista das construções, escola que no Brasil teve representantes famosos como Oscar Niemayer e Villanova Artigas. Arkadi Bogdanov defende teorias sócio-arquitetônicas com áreas mistas de trabalho e de recreio, grandes galerias e dormitórios pequenos, para uma maior sociabilização das pessoas.

A idéia de a arquitetura promover o avanço social teve como precursor Fourier. Ele imaginou cidades-edifícios e, dentro delas, imaginou uma divisão com uma dúzia de temperamentos e centenas de combinações, em um sistema bem mais elaborado que o adotado pelo psicólogo Michel Duval na trilogia. O curioso é que todas as tentativas reais de criar esses falanstérios acabaram não seguindo à risca as complexas recomendações de Fourier, então, nunca se soube se estavam certas ou não.

Outro exemplo é a utopia projetada por Robert Owen, com suas cidades industriais que exigiam de seus moradores um comunismo de tipo monástico ou militar. Essa sim foi aplicada na Inglaterra e nos EUA, com sucesso por um tempo, mas logo depois se viram isoladas e abandonadas. A receita para aproveitar o exército de desempregados que poderiam levar a um quadro de anarquia acabou descartada por ela mesma representar uma ameaça ao status quo.

Jameson destaca a invenção das cidades e dos edifícios como formatação da criação da própria utopia. "Nós identificamos a cidade em si como uma forma fundamental de imagem utópica (como se o molde da cidade refletisse o cosmos), talvez nós deveríamos abrir espaço para o edifício individual como um espaço de investimento utópico, aquela parte monumental que não pode ser o todo e, assim mesmo, tenta expressá-lo” (2005, p.4).

Jameson se fascina especialmente pelo prédio projetado em Noctis Labyrinthus para assobiar, chiar ou apitar segundo o ângulo dos ventos fortes de lá no momento: "No dia da inauguração, o vento que baixava das encostas de Noctis se viu incrementado por rajadas, e a música flutuou como em uma composição triste, colérica, dissonante ou harmônica em súbitos fragmentos. Parecia a obra de uma mente, talvez de uma mente alienígena.” (1993, p.324)

Outros locais lembram, pelo fantástico e mirabolante, as tradicionais cidades imaginárias da ficção científica, sempre com um quê de orientalismo, afinal, projeta-se o outro alienígena com a ajuda da alteridade mais à mão no imaginário ocidental. Algumas cidades-tendas recordam também as Cidades Invisíveis, do escritor italiano Italo Calvino, por sua leveza, por sua geometria particular e pelos materiais inusitados utilizados em sua edificação. E no último volume, Blue Mars, elas ganham tons de delírios imagéticos, principalmente quando a humanidade se expande para Mercúrio e Vênus.

Imaginando cidades se visualiza a utopia como aquela outra dimensão imanente ao mundo humano da luta, como aquele lugar sem lugar no mapa deste globo, um "outro mundo deste mundo" - sem a transcendência do sentimento religioso, mas com a força das possibilidades hipotéticas. Como diria Suvin (1984), à página 71 de seu livro: "A utopia é um impossível possível”. Nesse trecho, o teórico faz uma comparação com a sátira, que ele define como o "possível impossível”, e 
sentencia que os utópicos explicam o que os satíricos só insinuam. O possível se relaciona com o estilo científico e o tratamento realista que o gênero dá aos vôos futuros, que compõe o “impossível”, o “fora de alcance”.

A mistura de passado, presente e futuro repete a química da utopia, fazendo o leitor, ao mesmo tempo, estranhar e se identificar com os cenários, como se visitasse o Epcot Center, centro de diversão na Flórida que proporciona uma volta plastificada ao mundo sem sair dos domínios do império de Walt Disney. O mundo disneyficado é a fotografia retocada da sociedade de nosso tempo, em uma perspectiva açucarada que oculta os conflitos sociais e políticos.

Mas também, como Jameson explicita, essa disneyfication é um complicador para o localismo contra o universalismo, ou seja, do federalismo proposto pelo ensaísta e pelo escritor contra a unificação que o atual processo de globalização impõe ao mundo - outro fenômeno que pasteuriza a humanidade é o turismo, e há turistas japoneses visitando a marciana Sabishii por parecer mais com a imagem de Tóquio que a própria cidade terráquea no futuro. Essa ênfase de localismo versus universalismo também mostra o ponto de vista de Jameson, que fala dos Estados Unidos, país que obriga na atualidade o mundo a adotar o "universalismo mercadológico", mas, ao mesmo tempo, se fecha em uma visão paroquial, pelas próprias palavras do crítico.

O teórico propõe uma utopia que se parece a esse nosso mundo globalizado, mas com os sinais trocados: as pessoas, e não o dinheiro, são livres para ir onde quiserem. As pessoas poderiam escolher entre várias utopias para viver, e não, como agora, que podem escolher onde investir (isso para a parcela pequena que não faz parte da massa de "sujeitos monetários sem dinheiro", como os excluídos do sistema atual são definidos pelo pensador alemão Robert Kurz).

A valorização do deslocamento humano dá a possibilidade de começar do zero, e transformar o planeta em uma rede de cidades ligadas pela geografia, mas separada pela história - mesma lógica com a qual o historiador francês Fernand Braudel descreve a história do mar Mediterrâneo e seus portos de civilizações diferentes, lógica essa que é resgatada por Jameson para defender uma globalização que respeite as diferenças.

O exemplo mais curioso da lógica disneyficada é Vanuatu, uma versão indoor da cultura polinésia. Um túnel de lava abriga um lago com três ilhas e três aldeias, com temperatura ambiente bem tropical e fileiras de palmeiras, além da indispensável “cordialidade sexual” das nativas.

Esse mesmo tom de parque temático se repete no refúgio principal da areofania, Zigoto, e sua cópia reduzida Gameto (criado porque o abrigo inicial sofreu quedas de gelo de seu céu artificial). Os seguidores de Hiroko moram em casas de bambu e passeiam em praia com dunas e ondas provocadas por uma máquina - tudo isso sob a cobertura de gelo da calota do Pólo Sul.

Como no estilo bogdanovista, há uma valorização dos lugares coletivos, como mostra esse trecho que descreve como as crianças ectógenas se comportavam em Zigoto: "Subiam por escadas em caracol das grandes casas de bambu e brincavam de esconde-esconde nos quartos sobrepostos e nas pontes pênseis que comunicavam os diferentes lados. Os dormitórios de bambu formavam uma meia-lua que contornava a maior parte da aldeia. Os grandes troncos tinham uma altura de seis a sete segmentos, e cada segmento albergava um quarto, mas reduzidos quanto mais acima estavam. As crianças ocupavam os quartos individuais na parte alta: cilindros verticais com janelas de três a quatro metros de largura, como torres nos castelos de fábulas. O segmento intermediário alojava os adultos, quase todos quartos de solteiro, mas também havia de casal. As salas de uso comum 
ocupavam os pisos inferiores.” (1994, p.27-8)

Zigoto e Gameto parecem municípios edênicos que se espalham pelos rincões prósperos do mundo, afinal, as microutopias estão há muito tempo à disposição das classes altas e médias, que dispõem também do privilégio de ir e vir pelo mundo (e até fora dele com o já previsto turista espacial) com o laissez-passer que o dinheiro lhes confere - Jameson e Robinson imaginam isso como um direito para todos.

A utopia na versão norte-americana, que depois foi globalizada, migrou para dentro dos condomínios, que recriam um mundo ideal, isolado por cercas elétricas, circuito interno de vídeo, seguranças e guaritas. Esses vales resplandecentes e emparedados colocam em questão se as microutopias são válidas (a lógica utópica não é “ou todos são felizes ou ninguém é”?). O próprio Robinson vive em um condo, uma Village Home de mentalidade cooperativa com muitos espaços coletivos e poucos privados, como a dupla de redutos polares da resistência marciana.

Já Sabishii é também um simulacro de cidade, dessa vez um misto da moderna Tóquio e da tradicional Kioto, fundada por japoneses que chegaram a Marte só sete anos após os pioneiros. Está encravada em uma região de pedras grandes e irregulares, com altares do xintoísmo e do zenbudismo escavados nos desfiladeiros e um dragão desenhado no solo com rochas de lá. A cidade, sede da Universidade de Marte, é cercada ainda por um bosque bonsai. Seus habitantes são nipomarcianos de cabelo comprido, usando desgastados macacões marrons e andando descalços. Sabishii é a capital também do demimonde. Esse termo, que originalmente em francês classificava as cortesãs que transitavam na aristocracia, denomina na trilogia as localidades que servem de transição entre os refúgios da resistência e as tendas corporativas.

Outras cidades surpreendem pelas maravilhas de possibilidades e pelas soluções para as condições locais. É o caso da capital da lua marciana em forma de batata Fobos (1993, p.338-9): "Stickney resultou ser uma pequena cidade movimentada, a cúpula de uma cratera coberta com o mais novo em revestimento contra a radiação, e o solo em círculos concêntricos escalonados que descendiam até uma praça no fundo. Os círculos se alternavam entre parques e edifícios de dois andares com jardins nos telhados. Havia redes no ar para as pessoas que perdiam o controle de seus saltos através da cidade, ou que decolavam por acidente; a velocidade de saída era de $50 \mathrm{~km} / \mathrm{h}$, de modo que era quase possível escapar da gravidade”.

Os anéis de arborização de seu urbanismo lembram o paraíso socialista pintado por Bellamy em Looking Backward, livro que inspirou o Garden City Movement na virada do século 19 para o 20 principalmente na Inglaterra, EUA e Alemanha, e que no Brasil resultou em empreendimentos nada coletivistas como a região paulistana dos Jardins e os posteriores condomínios fechados importados junto com o pacote american way of life a partir dos anos 70 .

Já em Green Mars, Medusa, cidade misteriosa visitada por Nirgal, Coyote, Art e Sax, é confundida por eles com uma localidade bogdanovista porque as construções têm formas arredondadas. Mas a suposição é descartada. Toda feita de alabastro, a cidade é povoada apenas por estátuas de pessoas fazendo coisas do dia-a-dia, como comprando no mercado ou jogando xadrez na praça, crianças brincando e leões passeando como gatos pelas calçadas. É como se uma Medusa tivesse transformado em pedra uma cidade utópica, congelado-a em sua rotina, em sua temporalidade diária. A conclusão da razão daquilo só vem quando os quatro deixam o local e divisam um baixo relevo com a figura da mulher com a cabeleira de cobras em um paredão de pedra que olhava para a cidade. 
Por seu lado, as capitais corporativas são também reproduções de suas similares da atualidade. Vizinha ao elevador espacial está Sheffield, que é pontilhada por prédios de escritórios de até 50 andares e portas giratórias para entrar. Seus bulevares são arborizados e pontuados de restaurantes como o Antonio’s, de cozinha internacional ou italiana.

Mas a capital das transnacionais em Marte é Burroughs, que acaba submersa ao final de Green Mars. Segue o mesmo receituário de edifícios corporativos, mas com restaurantes no alto do despenhadeiro que cerca a cidade ou à beira do canal que corta o parque central, onde as personagens podem fazer seus almoços de negócios com vinho e pedir sua sobremesa com o café.

O nome da cidade é especialmente interessante, afinal, o sobrenome Burroughs é ligado a dois escritores que aliaram em suas biografias ficção científica e dinheiro.

O primeiro é Edgar Rice Burroughs (1875-1950), imortalizado como o criador de Tarzan, mas que escreveu 12 livros ambientados em Marte depois do primeiro "A Princesa de Marte" ser um sucesso de vendas - ele mesmo admitiu que sua ambição monetária foi o motor de tantos livros sobre o planeta. Hoje, a Edgar Rice Burroughs Inc. cuida dos direitos das personagens que ele criou e sua sede é em Tarzana, subúrbio de Los Angeles em que o escritor imaginou erguer um parque similar ao de Walt Disney e seu Mickey.

O outro é William Burroughs (1914-1997), escritor símbolo da geração beat que, com suas visões alucinadas e cidades sem governo, inspirou escolas dentro da ficção científica como a new wave e a cyberpunk. O detalhe de sua biografia é que ele era neto do fundador da Burroughs Corporation, fabricante de calculadoras e computadores, e viveu da mesada da família boa parte de sua vida.

Os refúgios da resistência são batizados com nomes sugestivos como Prometheus (escondido atrás de uma porta em um despenhadeiro, habitado por francófonos e decorado com plantas e tapetes por todos os lados), Christianopolis (povoado por "verdadeiros cristãos” contrastando com a religiosidade gananciosa de Phyllis Boyle) ou ainda Gramsci, Mauss Hyde e Bogdanov Vishniac.

O nome das cidades marcianas de Robinson também revela um procedimento bem norteamericano, batizar suas cidades com nomes de localidades de outros países, especialmente européias. Isso aconteceu pela expansão acelerada na conquista do Oeste dos EUA (daí surgirem cidades como Paris, no Texas, e Brazil, em Ohio). Em Marte não é diferente o ritmo frenético de construção de cidades, dessa forma surgem Nicosia, Cairo e Odessa.

Mas as cidades de Robinson não são apenas desafios geométricos, experiências científicas, inovações estéticas ou puros decalques de locais já existentes. Mais do que formas elas encerram idéias por trás da arquitetura. Em uma punição quase bíblica, Burroughs é o símbolo da ideologia corporativa e acaba submergida por um mar, como se esse passado de Marte das metanacs fosse parar no subconsciente do planeta. As incendiárias Nicosia e Cairo também são devastadas, junto a outras cidades, no contra-ataque das metanacs como reação ao ímpeto revolucionário de 2061. Já a contracultural e mística Zigoto acaba embaixo de gelo da calota polar por ser uma utopia de equilíbrio instável.

E seus significados já surgem na própria concepção. No começo da trilogia, é reveladora uma passagem em que, logo após o pouso em Marte, Nadia explica para Sax o porquê de o armazém 
estar tão cheio: "Essa é uma cidade inteira, desmantelada e distribuída em peças (...) É uma cidade universitária. Com departamentos de primeira ordem em várias disciplinas.” Nadia está falando da futura Underhill, a primeira cidade, habitada somente pelos cientistas pioneiros em clima da mais pura utopia acadêmica.

É de lá que se vislumbra um mundo diferente, se mostra que o mundo do lado de fora é uma criação (a idéia que a verdade é uma ficção que esqueceu que foi tramada). Underhill repete a atualidade, quando as universidades viraram refúgio para as utopias - além de um componente residual pré-capitalista, a academia é um lugar estratégico para disparar críticas ao sistema hegemônico. A própria idéia de federação pode ser também uma representação desse universo paralelo que é um campus, com seus prédios que separam engenheiros, físicos, geólogos, biólogos, agrônomos, psicólogos e professores de letras (as utopias robinsonianas parecem separadas por departamentos).

Essa vida compartimentada resulta na especialização, na fragmentação, em personagens como os de Robinson, dá em idéias como as esferas modernas de conhecimento substituindo a ética religiosa e também na arte pós-moderna. Nesse aspecto, a interdisciplinaridade que Jameson pratica, mobilizando todas as ciências humanas em sua crítica cultural, mostra que é possível erguer pontes em um mundo tão despedaçado como faz o saber promovido por ele. 


\subsection{Enredo e figurino de época}

Outra marca da trilogia de Kim Stanley Robinson é o investimento do autor em mudanças de fundo no futuro que projeta, mesmo que a solução final seja no marco múltiplo bem ao gosto pósmoderno. Ou seja, ele não apenas encena uma versão high-tech do que acontece hoje, diferença essa que Jameson divide nas categorias estéticas de imagination e fancy, emprestadas do poeta e teórico romântico britânico S.T. Coleridge (1772-1834), que criou os termos para desmascarar as firulas e lantejoulas do classicismo e do barroco, escolas anteriores a sua. Como os badulaques voltaram à moda na virada do século 20 ao 21, o crítico norte-americano recupera essa noção forjada pelo célebre inglês para diferenciar a inovação rasa da profunda.

O conceito de fancy descreve o tipo de criação artística que se concentra no detalhe, no figurino, no mise-en-scéne. Por isso, sua promessa de futuro é regida pelo fetichismo, seja o da tecnologia, o do design ou o da novidade pela novidade. O universo da fancy, com seus caprichos e rodeios, está muito mais preocupado com a decoração que com os temas que movem a ação, encobertos por tanto ornamento.

Já a imagination estaria ligada a imagens cerebrais mais racionais e mais próximas dos sentidos, menos extravagantes que seu par superficial. Jameson simplifica a distinção e diz que, em termos literários, fancy é o estilo, enquanto imagination pode ser lido como o enredo - o crítico faz ainda paralelos dessa divisão com os conceitos-pares de belo/sublime de Immanuel Kant e de expressão/construção de Theodor W. Adorno.

Vale uma comparação rasteira para deixar bem clara a diferença entre os conceitos: no desenho animado Jetsons, do estúdio Hannah-Barbera, uma família de classe média do início dos anos 60 é transportada para o futuro, mesmo procedimento feito nos Flintstones, rebobinados para a pré-história (o que naturaliza aquele estilo de vida, afinal, ele vem do passado longínquo e permanece no futuro). Na verdade, o american way of life ganha uma nova roupagem, mas por trás da casca (veículos a jato, casas aerodinâmicas, domésticas robotizadas e máquinas que servem comida) lá está a mesma sociedade da época (machismo, capitalismo, moralismo, etc.).

Ou seja, zero de imaginação nos temas fundamentais e muita firula para encobri-los. Fancy regeria o universo das pseudonovidades, algo possível, até previsível dentro do real. Já imagination seria o motor para a novidade (o novum), aquilo que de tão revelador, necessário e capital parece irreal.

Jameson é taxativo na introdução de Archaeologies of the Future (2005): "Nossa imaginação é refém do nosso próprio modo de produção ( ...) Isso sugere que, ao melhor, a utopia pode servir ao propósito negativo de nos fazer mais conscientes da nossa prisão mental e ideológica e que, consequentemente, as melhores utopias são aquelas que fracassam de forma mais completa.” O paralelo é tremendo com o propósito da psicanálise que, segundo o próprio Freud, é que o consciente ganhe terreno diante do imenso mar do subconsciente que nos governa com suas pulsões e paixões sem que possamos controlar - para ilustrar a idéia, o austríaco usa a metáfora dos diques a ampliar o território dos Países Baixos diante das ondas e marés do mar do Norte.

Mas, como toda boa arte utópica, o trabalho intelectual, preocupado com temas fundamentais, tem de conviver com o ofício retórico. Na ficção científica, um tipo de romance histórico que se deslocou para o futuro (e, ao contrário da fantasia, tem um nexo com passado e presente), o escritor 
se ocupa também do papel de figurinista e encenador.

O pormenor, o estilo e a ambientação estão na extensa obra de Robinson, até como reflexo dos anos de pesquisa que incluiu a colagem de elucubrações, e visões de seus antecessores literários, além de sua produção própria de delírios. Então, não faltam na trilogia dispositivos, bebidas e drogas saídas da mente de Robinson. Um exemplo fantástico é a roupa de pássaro que dá a Zo as propriedades aéreas de uma ave, um símbolo do desejo de liberdade que a utopia também prefigura. Há também exemplos de travestismo utópico, como vestir os cidadãos de determinada cidade de macacão, para simbolizar a estatura comum de todos como trabalhadores, assim como em outras obras se vestia o proletário de monge para colar nele os hábitos monásticos.

Não muito longe da receita dos Jetsons, o ficcionista projeta a permanência de vários hábitos muito em voga nos anos globalizados da última década do século 20 - revelando que se está falando de nossos dias e não de séculos vindouros. Lá estão, de forma residual ou consagrada, os hábitos alimentares globalizados, como o café expresso, a barra de cereal, o espaguete, o burrito e os restaurantes com apóstofre, como o Antonio’s.

Também não falta o ritual da happy hour, como Maya e Frank tomando brandy após um dia estressante de politicagem, e a praticidade do fast food entre uma tarefa e outra, como Nadia esquentando lasanha congelada no forno de microondas.

Mas o trabalho de invenção é também unir junções para criar. Há dois exemplos que têm papel importante na trilogia: a kavajava (coquetel de café e kava) possibilita as longas sessões dos congressos; e os consoles de pulso (misto de computador e celular) são o principal meio de comunicação entre as personagens espalhadas pelo planeta. Esses dois elementos ilustram a dialética de identidade e diferença, entre presente palpável e futuro potencial.

Deslocada de seu contexto, a kava, bebida ritual e alucinógena das ilhas Fiji (Oceania), é misturada com o café, infusão estimulante das horas de serviço - taxado como bebida de sobremesa, o cafezinho virou uma das principais commodities do capitalismo por sua função de aumentar o rendimento dos trabalhadores. Ou seja, é mescla da ilusão, da invenção com o trabalho para forjar uma constituição, um novo começo.

A trilogia de Robinson é pródiga também em fabricar drogas nada ritualísticas. Há os gases inaláveis pandorfo (fictício) e o óxido nitroso (real e mais conhecido como o "gás hilariante”). Mas a mais usada é a pípula de omegendorfo, inventada por Vlad Tannev, adotada por John Boone e experimentada até pelo nerd Sax Russell. É um estimulante mental e sensorial que pode ter inspiração em drogas reais (ecstasy) ou fictícias, já que a sci-fi esconde muitos entorpecentes em suas páginas.

A presença de alucinógenos e estimulantes é mais marcante no gênero durante os anos 60, com os movimentos de contracultura influenciando obras que relatavam a percepção de mundos paralelos ou por trás da aparência graças à ação dos entorpecentes. Mas também é importante na produção recente como na linha cyberpunk. Uma das substâncias fictícias mais célebres é a especiaria melange na saga da série Duna, de Frank Herbert. O material possui propriedades geriátricas e é fonte de poder, afinal, permite viagens espaciais. Ela só é encontrada no planeta Arrakis, produzida pelos vermes gigantes que habitam o solo arenoso do local.

Outro narcótico famoso da sci-fi é a ultramorfina, usada pelo torturado sacerdote católico no 
desenrolar de Hyperion (1989), de Dan Simmons. O próprio Kim Stanley Robinson já tinha experimentado criar alucinógenos em sua bibliografia anterior. No livro The Gold Coast, em uma Califórnia do século 21, os entediados moradores de Orange County usam com conta-gotas drogas sintéticas com denominações sugestivas como visionaria, afabilidade social e doce Califórnia. A personagem criadora das drogas, Sandy Chapman tem dificuldade em comercializá-las porque ele mesmo é usuário e arrasta sua existência entre uma venda e outra. Já Case, protagonista de Neuromancer, é obrigado a implantar um fígado novo já que o seu foi devastado pelo vício - outras partes de seu corpo são degradadas por implantes eletrônicos na Bíblia cyberpunk.

A fancy invade também na trilogia de Robinson o terreno que seria da imagination quando um enxame de subplots decora a linha mestra da trama. Na trilogia, as mais corriqueiras dessas historinhas pré-moldadas são os suspenses meteorológicos, nos quais os personagens são colocados em situações de perigo para se safarem no último trago de oxigênio ou na última tentativa de senha para entrar em uma cidade-tenda. Após o primeiro desses subplots fica a sensação que a tensão só foi criada para ilustrar o inóspito que Marte é, mas a dissipação conseqüente reforça o poder de superação dos homens.

Mas há adereços que dão indícios dos temas de fundo. É o exemplo da língua falada no mundo criado por Robinson. Como se trata de um futuro próximo, não há uma língua inventada como em outras obras da ficção científica. O linguajar marciano é um inglês adaptado à nova realidade. Uma espécie de inglês standard em que são acopladas algumas palavras do árabe (principalmente para descrever a paisagem, afinal, o idioma do deserto guarda nome para cada tipo de cenário árido) e do japonês (que com os conceitos de nissei, sansei etc. denominam as gerações nascidas no planeta vermelho). O russo também é falado lá e cá, principalmente em cidades bogdanovistas. Contudo, como na atualidade, um inglês funcional é a língua franca nesse Marte vindouro.

O detalhe idiomático revela que por trás da superfície globalizada (influências vindas do hemisfério oriental do mundo) é a lógica norte-americana a que predomina e serve de base tanto para a visão de mundo como para a comunicação.

Isso também acontece nas influências específicas à ficção científica. Robinson mantém diálogo intenso com seus antecessores de língua inglesa, mas as referências à tradição russa entram apenas como citação, muitas vezes de forma cifrada. A mais frutífera delas esconde por trás o sobrenome da personagem Arkadi, que traz à baila o russo Alexander Bogdanov (1873-1928), médico, economista e escritor de ficção científica. No começo do bolchevismo, ele era o segundo em popularidade no grupo político, só perdendo para o líder Vladimir Lenin, que o acusou de idealismo e, por isso, foi expulso do movimento em 1909. Com o aumento da repressão czarista, o Bogdanov da vida real exilou-se na ilha italiana de Capri com outro escritor bem mais célebre no ocidente, Máximo Gorki. Durante a Primeira Guerra Mundial, atuou como cirurgião no front e não teve participação nos eventos que geraram a Revolução Comunista de 1917. Chegou a afirmar que eram um "delírio de um louco" as Teses de Abril de Lenin, que reforçavam a idéia de revolução proletária e negavam apoio ao governo menchevique após a queda do czar.

Depois veio a ocupar o posto de professor de economia na Universidade de Moscou e continuou desenvolvendo pesquisas médicas. A principal delas era tentar o rejuvenescimento do corpo por meio da troca de sangue. Chegou a aplicar o método em Maria Ulianova, irmã de Lenin, em 1924. Em 1928, acaba morrendo como resultado de sua obsessão com o tema. Ele pegou malária e tuberculose ao receber sangue de um estudante seu. 
Outro fato que o deixou conhecido foi escrever em 1908 a narrativa utópica ambientada em Marte chamada Estrela Vermelha, com toques feministas (as mulheres se libertam da "escravidão doméstica”) e defesa do operariado (os trabalhadores decidem quantas horas trabalham). Na ficção, que depois ganhou o subtítulo de A Primeira Utopia Bolchevique, também está presente o método de rejuvenescimento por meio de transfusões de sangue, que acabou causando a sua própria morte e que inspirou Robinson a colocar o tópico em sua saga marciana (o curioso é que a personagem Vlad Taneev tem uma trajetória mais parecida com o Bogdanov histórico, afinal, é médico e economista, e co-criador do tratamento geriátrico, como também da eco-economia).

Mobilizando esses exemplos linguísticos, cenográficos e referenciais, fica sugerido o que no capítulo conclusivo é melhor problematizado. Isto é, a construção da trilogia marciana esconde, pouco a pouco, um componente importante de fundo: por trás da fancy cosmopolita e globalizada está uma imagination tipicamente norte-americana. 


\section{QUESTIONAMENTOS}

Após a apresentação do tema no primeiro capítulo e a análise detalhada da trilogia marciana na segunda parte, este último trecho da dissertação guarda o objetivo de lançar perguntas e propor respostas sobre um dos temas principais da obra de Robinson, um escritor sem dúvida utópico, mas que mostra ao longo da obra sentimentos conflitantes sobre o assunto - aliás, como boa parte da esquerda, dividida entre a idéia de ruptura e o compromisso jogar o jogo democrático.

O assunto pinçado para a discussão aparece ao longo desta dissertação, mas aqui ele é problematizado: a opção pós-moderna de Jameson e Robinson de apostar em uma federação de utopias (no lugar de uma solução totalizadora, sintética, sincrética ou mais abrangente) como o modelo mais adequado para os tempos em que vivemos, em que a hegemonia do capitalismo impõe que não há alternativas a esse sistema. Para eles, só a idéia de que há e se pode imaginar alternativas já é toda uma revolução no pensamento único atual - ainda mais preponderante nos EUA.

É como se ficasse receitado para a hegemonia dos EUA em tempos de globalização um antídoto feito da essência original norte-americana: o espírito federalista e descentralizado da independência de 1776. O plano original corrigiria os desvios do percurso, transcorridos mais 200 anos.

Esses EUA, de tom solar e inaugural, estão personificados em John Boone, que não por nada tem o sobrenome do mítico Daniel Boone, personagem lenhador e desbravador das florestas da América do Norte. Outra referência indireta envolve seu prenome. John é uma alusão direta a John Kennedy, com o paralelo claro na introdução ao capítulo 6 de Red Mars (Armas Sob a Mesa), em que aparecem uma série de depoimentos de pessoas sobre o que estavam fazendo na hora em que o líder foi morto, coisa que todo norte-americano vivo na época do assassinato do presidente JFK sabe e faz questão de lembrar.

Já Frank Chalmers é o lado atual e sombrio do país, que vaga pelo mundo como seu doppelgänger a enfiar goela a baixo o pacote dito democrático no Iraque, Afeganistão etc. Em um trecho de Red Mars, um líder sufi avisa John que Frank é seu nafs, termo que define o "eu maligno" presente no peito dos homens.

Por isso, é revelador observar que na trilogia de Robinson a figura dos Estados Unidos, como governo e nação, se esfumaça com o decorrer da narrativa, cumprindo um papel importante em Red Mars (Frank Chalmers, secretário dos EUA em Marte, é a personificação institucional da "Land of Freedom" e, quando morre, leva com ele a representação oficial). Mas as referências ao país praticamente desaparecem no último tomo. É como se a superpotência tivesse explodido e seus destroços se espalhassem pela obra inteira, e recolhê-los é a única forma de identificar a visão de mundo por trás da obra.

E essa explosão acontece quando Marte vai se endereçando para uma solução federalista, cujo maior paradigma é justamente os EUA, pioneiro nesse regime em países de grandes dimensões e exemplo para os outros existentes pelo mundo, inclusive o Brasil.

A alternativa para a globalização (chamada pelos críticos de "americanização”) da mesmice para o mundo, que derruba todas as soberanias, é a retomada de uma espécie de pacto federal, que é, como Alexis Tocqueville definiu em A Democracia na América, o confronto de duas soberanias, a 
local (da cidade-estado ou da província) contra a universal (nacional ou supranacional). O equilíbrio entre as duas partes é dado por uma legislação complexa, mas que deve ser conhecida por toda a população, como apontou o pensador francês.

Na trilogia marciana, o passado federalista derruba o presente centralizador em um futuro em que a presença dos EUA se esvai, mas é prefigurada em vários lugares, inclusive no retrato que se faz de Marte. Essa lógica de fusão dos três tempos foi analisada por Sigmund Freud, que afirmou no ensaio "O escritor e o sonho diurno" ("Der Dighter Und Das Phantasieren”) que "passado, presente e futuro são como as contas de um colar incrustadas pelo desejo”.

É justamente esse mecanismo que possibilita o fantasiar, como escreveu o pai da psicanálise: "A fantasia oscila de certo modo entre os três tempos, os três momentos temporais de nossa representação. O trabalho mental começa com uma impressão atual, uma ocasião do presente que foi capaz de despertar grandes desejos na pessoa e, a partir de aí, remonta à recordação de uma vivência anterior, infantil na maioria das vezes, na qual o desejo se realizava, e então cria uma situação referente ao futuro, no qual se configura a saciedade desse desejo.”

Ou seja, o presente imperial dos EUA da virada do século 20 para o 21 busca em sua infância como nação em pleno século 18 a inspiração para seus próximos passos, uma vez que é dada como certa a colonização de astros vizinhos nas próximas décadas, com orçamentos e pesquisas já adiantados.

Claro, Robinson mistura isso com citações à Revolução Francesa, Russa e outras tentativas de sociedades com forte inclinação igualitária. Tudo para apresentar sua alternativa cheia de alternativas, perante o presente de um reinante "there is no alternative". Mas fica no final uma sensação próxima àquela transmitida pela seguinte frase de Adorno: "O salto para o futuro, passando por cima das condições do presente, aterrissa no passado.” Ou aterrissa em um eterno presente de onde não se consegue sair de vez.

Para começar, a solução federalista de utopia é sintomática de uma esquerda sem direção em uma época estrangulada por uma direita fechada no chamado Consenso de Washington, o mesmo, que mesmo bastante desacreditado, anda em funcionamento ainda (foi revisado em 2004 pelo FMI, após uma série de fracassos que começaram com a crise asiática de 1997 e deram na quebra da Argentina em 2002).

A escrita da trilogia marciana coincide com o auge do acerto neoliberal de 1990, receitado tanto para uma América Latina quebrada quanto para os países asiáticos que queriam virar "tigres" e também para o Leste Europeu pós-socialismo. O consenso gozava naquele tempo de prestígio que as novidades têm, apesar do prefixo "neo" evidenciar que pouco havia de diferente daquela versão, digamos, vintage do liberalismo - no final, o crescimento dos países foi pequeno diante dos estragos sociais que os planos do FMI, Banco Mundial e Tesouro dos EUA fizeram. 


\subsection{Solução pós-moderna para se chegar à sociedade ideal}

Se cada utopia se estuda como reflexo das crises específicas que se pretende resolver, a de Robinson desconfiava da solução centralizadora, visto que essa estava nas mãos dos conservadores, enquanto a outra alternativa desse tipo, a experiência do bloco comunista, tinha caído pouco antes.

Além de trazer um forte apelo democrático, a saída federalista retrata essa esquerda tão esfacelada como a própria arte contemporânea. Daí uma encaixar na outra, pela visão de Jameson e Robinson, que acenam com um sistema político tão fracionado quanto as quebradiças alas das artes, da esquerda e, generalizando mais, da própria sociedade atual. O ficcionista quis contar uma saga em que todas as alas fossem contempladas. Por isso, o fracasso da revolução de 2061. Por isso, as difíceis tentativas ao longo de Blue Mars para se chegar ao final feliz e “progressista”.

A morte de John na abertura da saga também afunda a solução sincrética. Ele prega que se esqueça o passado e se reinvente do zero, do vazio a solução marciana para a humanidade, convocando a população a "escolher, cortar e unir" os genes culturais, o passado, em uma posição mais ativa e menos reativa em relação à história. John é o líder sincretista, defendendo uma síntese das comunidades em uma só cultura local, uma fusão global e total, como se encerra na idéia de sincretismo. Essa posição fica clara em sua relação com os assentamentos sufis. "John vê os sufis como seu outro/irmão árabe e como uma prova viva das soluções sincréticas - não só porque os sufis têm uma tradição religiosa sincrética como também porque eles são cientistas e ao mesmo tempo místicos” (FRANKO, 1997). O sincretismo também não é a panacéia para se chegar à ótima república, afinal, a cultura brasileira foi moldada em um processo desse tipo e gerou uma das sociedades mais injustas sobre a terra (por trás da mistura das crenças, raças e culturas estão claras as subdivisões abismais do país, que resistem a ciclos econômicos e partidos no poder).

De qualquer forma, é revelador que justamente o líder que busca uma unificação, uma mistura ideológica, seja assassinado por fundamentalistas, ou seja, aqueles que não querem ver suas idéias diluídas em qualquer fusão de fés. Ao final, a trilogia reforça a solução sectária ao adotar o multiculturalismo, que com sua lógica de respeitar as diferenças acaba, na prática, por criar ainda mais trincheiras.

O utopista toma partido por um lado ou outro. E Robinson vai pelo flanco dos reformadores, revolucionários de veludo e pelos liberais multiculturais.

A utopia reproduz o aparato cênico de seu tempo, o imaginário, a preocupação pelos temas contemporâneos de sua escrita (um exemplo é a fé na ciência que Robinson deposita na trilogia marciana e que em livros posteriores fica menos cega). Claramente, entre as angústias de época relatadas por Robinson estão a ecologia, a migração de trabalhadores, o poder das corporações e o papel dos cientistas na sociedade. As possibilidades plurais se abrem, mas não se fecham, continuam como possibilidades, o que forma a sina da pós-modernidade.

A saída federal tem uma feição pós-moderna por colocar suas fichas justamente na fragmentação de mundos ideais como fórmula. Dessa forma, o sistema federalista serviria como marco legal e neutro que permitiria a constelação de lifestyles independentes e interligados. Trocarse-ia o lastro econômico (o capital) que serve de solvente universal por um político (o federalismo), com a mesma função de meio de cultivo de microutopias. 
Mas será que essa cara multifacetada não é resultado da perspectiva desde o campo do consumo, com suas infindáveis opções de utopia (na trilogia vira até marca com o conhaque Utopia)? Dessa maneira não se deixa de lado o ponto de vista da produção, que na nossa sociedade é bem unificado sob a tutela do capitalismo? As utopias de bolso, como as sociedades alternativas, são válidas ou são uma miragem que atrapalham o caminho para um futuro melhor para todos? Ou será que também essas várias utopias simultâneas não são a representação de um tempo (pós-queda do Muro de Berlim) em que o pensamento de esquerda está esfacelado em tantos grupos e micropolíticas? Será que a obsessão na trilogia em evitar a morte também não é uma figuração da fuga de uma solução inevitável, de uma palavra final sobre o assunto?

Como o próprio Robinson disse em entrevista citada acima, vivemos um tempo em que se espera e se imagina de tudo, menos uma mudança profunda. Ou seja, o mundo do consumo se inova a cada instante, mas o da produção segue o mesmo há dois séculos, só que cada vez mais acelerada pelas inovações tecnológicas. A própria vida cotidiana parece um cenário de ficção científica, mas sem pitada alguma de utopia nela.

No terceiro volume da obra El Pensamiento Utópico en el Mundo Occidental, de Frank e Fritzie Manuel, tem uma frase lapidar sobre o assunto: “As sociedades capitalistas não querem tratados teóricos e morais que advoguem o estabelecimento de formas ideais dentro do âmbito vigente tecnológico-científico, pois sua intenção patente é a maximização das capacidades para o consumo de bens e serviços” (1984, p. 372). Essa potencialidade e essa falta de regras é que, por exemplo, fomenta a indústria da pirataria, que é o capitalismo em sua forma virótica.

Como o sistema está a serviço da irracionalidade, as utopias produzidas em seu seio buscam ser mais racionais, lógicas, porém, os resultados tendem a uma cortante descontinuidade, como na obra de Robinson.

O que Jameson e Robinson propõem é uma invasão da lógica do consumo para a esfera da produção, uma sugestão tão atraente como deixar o trabalho em uma monótona linha de montagem e ir se divertir nas galerias comerciais entre tentadoras vitrines e gôndolas, com direito a uma maisvalia de diversão. Com modelos novos, outros copiados do passado e versões residuais do modo atual, Jameson e Robinson querem que se reinvente a produção, e dessa forma recriar as relações humanas, que se moldam por ela.

E esse homem que estende sua relação com os bens de consumo para os bens de produção é próximo daquele "eu flexível”, definição adorniana para o homem que muda constantemente para consumir e ser consumido (afinal, ele mesmo é submisso à propriedade). Mas essa idéia acaba se mostrando uma compensação em um tempo sem perspectiva de grandes mudanças políticas - a própria democracia obedece aos ditames da concorrência capitalista de publicidade e consumo de lemas, slogans e candidatos.

A revolução migra do imaginário coletivo e se refugia no subjetivo. O “eu” é que se reinventa de um dia para o outro em mudanças radicais dentro da célula corporal. O deslocamento é apontado por Zizek. "Em nossa era pós-ideológica, em vez de tentar mudar o mundo, deveríamos reinventar a nós mesmos, todo o nosso universo, engajando-nos em novas formas (sexuais, espirituais, estéticas...) de práticas subjetivas?”, se pergunta o esloveno, para responder que, em meio ao desprezo pós-moderno pelas grandes causas ideológicas, a busca do "verdadeiro eu” é na verdade o esvaziamento do "eu” (2003, p. 104-5). Na utopia marciana de Robinson, o personagem pode trocar de "eu" trocando de cidade. 
A sociedade de consumo típica do american way of life já tinha sido antevista por Tocqueville (1973) em sua viagem de 1831 e 1832, com cujas observações escreveu seu clássico livro. Ele fala da paixão dos norte-americanos pelas “pequenas comodidades”, que é a própria vida para eles. “O bem-estar material, portanto, não é para eles o fim da existência; é um modo de vida. Consideramno, de certa maneira, como a própria existência e dele gozam sem pensar”, escreveu em $A$ Democracia na América.

Tocqueville vê um reflexo político nessa nova característica. O francês afirma que, mais temerária que a idéia de revolução, é a perspectiva da estagnação da sociedade humana, em esferas cada vez menores geradas pelo individualismo. "Tremo, confesso, ante a idéia de que se deixem possuir de tal maneira por um amor lasso pelos prazeres presentes, que desapareça o interesse por seu próprio futuro e pelos de seus descendentes e que prefiram seguir molemente o curso do destino a fazer-se necessário um súbito e enérgico esforço para endireitá-lo.” Nada mais atual para falar desses EUA jogado em um consumo à base de crediários a perder de vista, com habitantes preocupados com o gigantismo de suas pick-ups e fazendo vistas grossas para o aquecimento global, como se não fossem seus filhos e netos queirão enfrentar o problema.

O próprio Adorno fala em seu ensaio “Aldous Huxley e a Utopia” que Tocqueville teve uma visão mais crítica dos EUA que vários intelectuais do século 20, como o próprio autor de Admirável Mundo Novo. O francês descreveu uma sociedade que em muitos aspectos era superior à conturbada França da época, mas ao mesmo tempo mostrou, como acentua Adorno, um ceticismo, como diante da "falta de liberdade que permeia a igualdade desenfreada". Já o escritor inglês, que depois se instalou na Califórnia, receitou o reforço do individualismo como solução ao totalitário Estado Mundial de sua ficção. Adorno diz que esse é um falso dilema, afinal, o quadro totalitário é gerado pelo próprio reinado da idéia de indivíduo. "O individualismo irrefletido se impõe, como se o horror observado pelo romance não fosse ele mesmo fruto da sociedade individualista”, escreve o filósofo alemão em texto publicado no livro Prismas (2001).

Robinson foge desse impasse, escolhendo como solução algo intermediário entre o coletivo e o individual. Por um lado, ele opta pelo já discutido “narrador de múltiplas posições”, que guarda uma identidade com os personagens que persegue e, ao final, respeita todas as diferenças entre eles. Ou seja, a federação também é uma solução narrativa para Kim Stanley Robinson.

Por outro lado, existe no enredo uma opção pelo sectário, os partidos, as cidades-estados, o meio-termo entre o individual e o coletivo: a particularidade, a peculiaridade de cada grupo político. Como Jameson ressalta, a trilogia "está ricamente informada da onipresença das facções e das questões políticas que elas representam (as quais são, claro, unificadas pela ameaça exterior de um ataque armado da Terra)”, para diferenciar de outras utopias como as de More ou de Rousseau, em que há uma hostilidade à democracia devido ao temor que um partidarismo signifique a preponderância de grupos étnicos ou lobbies sobre o interesse comum (2005, p.165).

Mas na trilogia eles se multiplicam. Fora as entidades que defendem interesses terráqueos em Marte, há, entre os mais citados e naqueles presentes no congresso constituinte, os seguintes grupos: bogdanovistas, boonianos, verdes, vermelhos, Marte Livre, Marte Primeiro, Kakaze, neomarxistas de Bolonha, Liga Qahiran Mahjari e os schnellingistas - estes últimos seguidores do fracassado biólogo Oskar Schnelling que começou um movimento espiritual enquanto esteve na prisão de Korolyov, pouco depois da Revolução de 2061 (seus seguidores moram em covas em despenhadeiros e praticam uma vida comunal baseada nas leis da bioquímica). 
Zizek (2003) comenta como, após a queda do muro de Berlim, a esquerda européia e mundial ficou fracionada, em uma oposição bem ao gosto pós-moderno de Gilles Deleuze, divididos em grupelhos, brigando entre si e longe dos centros de decisões - o que lembra a briga pelo poder da resistência marciana após a tomada do poder.

"É a atual oposição ao capitalismo global que oferece uma espécie de imagem espelhada da afirmação de Deleuze acerca da exigência inerentemente antagonística da dinâmica capitalista (uma forte máquina de desterritorialização que gera novos modos de reterritorialização): a defesa de identidades particulares (culturais, étnicas) ameaçadas pela dinâmica global coexiste com exigências de maior mobilidade global (contra as novas barreiras impostas pelo capitalismo, interessadas principalmente na liberdade de movimento do indivíduo). Então é verdade que as tendências (essas linhas de fuga, como as definiu Deleuze) podem existir de forma nãoantagonística, como partes da mesma rede global de resistência? (...) É claro que essa lógica da multiplicidade funciona (pois ainda estamos tratando de resistência). Mas o que acontecerá quando - se esse for realmente o desejo e a vontade desse movimento - 'tomarmos o poder'? Como será a 'multiplicidade no poder'? Houve a mesma constelação nos últimos anos de decadência do socialismo realmente existente”, lembra o autor esloveno em Bem-Vindos ao Deserto do Real! (2003, p.170).

Ele arremete sobre os elogios atuais à multiplicidade na mesma obra: "Existe coisa mais monótona que a poesia deleuziana da vida contemporânea como a proliferação descentrada de multidões de diferenças não-totalizáveis? O que impede (e, portanto, sustenta) essa monotonia é a multiplicidade de ressignificações e deslocamentos aos quais se submete essa textura ideológica básica” (2003, p. 88).

Essas constelações, partidárias ou não, se encaixariam melhor nos retângulos de Greimas do que no esquema dialético simples de tese, antítese e síntese, afinal, há muito diálogo na trilogia, mas não há uma síntese. Há sim uma federação de contradições e negações, e esse é o motor narrativo da obra.

Mas até onde essa proliferação do individual e do coletivo não é uma solução aprisionada na mentalidade de nossa sociedade de consumo? Para Jameson, não há porque temer as utopias pósmodernas porque elas podem ser tão produtivas como as versões antigas (e mais unificantes), afinal, é o mundo que nos cerca, e simplesmente condená-lo é tão infrutífero intelectualmente quanto criar apologias em sua honra. Mas o crítico, em sua argumentação dialética, sabe muito bem que essa escola reproduz os meios de produção de nossa época: “O apelo à natureza humana não é mais plausível no espírito pós-moderno e construtivista do capitalismo tardio e suas ideologias. Essa é, na verdade, a ambigüidade do pós-modernismo como filosofia, que seu progressivo endosso da anti-essencialista multiplicidade e do perspectivismo também replica a mesmíssima retórica do mercado no capitalismo tardio como tal” (2005, p. 163).

É importante verificar até onde essas microutopias não são representações da micropolítica presente na esquerda em geral, e, especificamente, na norte-americana, com sua defesa de guetos, minorias ou formas de contracultura diante do puritanismo geral do país. A imaginação pára nesse cenário. Robinson tem uma opinião positiva dessa estratégia gradualista, de vitórias paulatinas e setorizadas. "É de conhecimento geral que a expansão dos direitos legais para mais e mais pessoas (mulheres, minorias étnicas, crianças, deficientes físicos e formas alternativas de vida) - isto é, progresso social na história, um traço utópico na história - tem sido um projeto e 
uma conquista da esquerda”, afirmou em entrevista à revista Infinity.

A multiplicidade está no aspecto político e cultural da sociedade (Jameson argumenta que a cultura reveste a política atual, em mais um efeito da pós-modernidade), mas do ponto de vista econômico e social nunca esteve mais unificado e concentrado em poucas mãos. Depois de afirmar que a descentralização na política deu em democracia local, pluralismo e uma valorização da diferença, o próprio Jameson diz que o mesmo processo não é mais possível no campo econômico: "Deve ser pensado que na área econômica a agenda de descentralização ofereceria um vantajoso espaço para a crítica do monopólio e das gigantes multinacionais; infelizmente a alternativa pequenos negócios, empreendedorismo e invenção - não mais assusta como algo viável” (2005, p. 162).

A situação fica ainda mais difícil se olharmos como é feita a política hoje em dia. Ela virou outro item de consumo nas democracias ocidentais, graças ao sistema eleitoral que precisa de campanhas que pasteurizam candidatos, e as pessoas escolhem partidos como se fidelizam com produtos, com rótulos, marcas, jingles e slogans como sabão em pó ou margarinas. Como politizar um mundo em que a política virou subproduto econômico?

Na verdade, a política está pasteurizada e empacotada para consumo em épocas de eleição, como nas festas de fim de ano. "A democracia é hoje o principal fetiche político, a rejeição dos antagonismos sociais básicos: na situação eleitoral, a hierarquia social é momentaneamente suspensa, o corpo social é reduzido a uma multidão pura passível de ser contada, e aqui também o antagonismo é suspenso”, escreve Zizek (2003, p.98).

Os políticos se tornaram só mais um ponto de incerteza em que se baseiam as grandes assertivas do tão seguro capitalismo - mas podem ser monitorados por pesquisas de opinião assim como o quase imprevisível clima é controlado por satélites. Por isso, Jameson pega essa lógica e a subverte ao propor uma utopia que seja um show room de formas de governo, economias e sociedades - já que o homem pós-moderno parece que não vive mais sem a miríade fantasmagórica de bens que o capitalismo lhe oferece.

Apesar disso, o teórico norte-americano aponta a componente utópica como o centro da composição. "O que identifica a trilogia marciana como uma utopia, e não como um romance político sobre uma revolução recorrente, é o lugar de sua premissa ainda não examinada, que no texto utópico tradicional sempre é encontrada em uma trincheira, que o separa da realidade cotidiana da Terra”, afirma Jameson em sua análise da obra (2005, p.415).

O curioso é que a receita utópica é apresentada por Sax, ou seja, tem uma cara de experiência científica, "um laboratório de laboratórios". É como se montasse a seguinte equação: "Resgate da política + revalorização do pós-moderno = federalismo.”

Mas esse resgate da política que Kim Stanley Robinson faz é a desejada pela ala progressista norte-americana, partidária do multiculturalismo, da micropolítica e do que, por lá, é chamado liberal, ou seja, o que estaria à esquerda do Partido Democrata. Mas é uma política que está longe de apontar algo diferente da ideologia já vigente.

Neste ponto, é interessante cotejar a crítica de Zlavoj Zizek, que aponta que o limite dessa ideologia da "livre escolha" pregada pelo multiculturalismo liberal é a construção de gêneros e targets para o mercado - que é o final da trilogia de Robinson a não ser uma utopia da "livre 
escolha” de utopias?

O esloveno tem como alvo o liberalismo da sociedade norte-americana, que é vendido como molde para esses tempos de globalização. Dentro desse sistema, a luta extrema é pelos direitos civis das minorias e a liberdade de expressão da maioria. "A única forma de garantir a servidão social é por meio da liberdade de pensamento”, decreta Zizek (2003, p.17). Nesta época pós-moderna, existe a liberdade de desconstruir, duvidar e distanciar-se, mas pensasse muito e agisse pouco. O lema pinçado pelo crítico, "pense o quanto quiser com toda a liberdade, mas obedeça", descreve como poucos o ambiente intelectual dos EUA, no qual todas as correntes de pensamento encontram espaço, até o marxismo teórico de Fredric Jameson na Universidade de Duke.

Na análise de vários intelectuais, o que impera é o cinismo nesse homem pós-moderno. Um dos que além dessa constatação é o sociólogo francês Pierre Bourdieu. "Há outras razões por que a ideologia parece já não ser um conceito da moda. Uma é o que se chamou 'falsa consciência esclarecida'. Em outras palavras, numa era pós-moderna, a idéia de que simplesmente funcionamos pautados pela falsa consciência é simplista demais: as pessoas, na verdade, estão muito mais cínicas ou astutamente cônscias de seus valores do que isso sugeriria. O que torna a questionar o conceito de ideologia. Por fim, existe a tese de que o que mantém o sistema em funcionamento é menos a retórica ou o discurso do que, digamos, sua própria lógica sistêmica: a idéia de que o capitalismo tardio funciona por si, de que já não precisa passar pela consciência para ser validado, de que garante, de algum modo, sua própria reprodução”, afirmou Bourdieu em entrevista a Terry Eagleton, datada de 15 de maio de 1991 e publicada no Brasil na obra Um Mapa da Ideologia (p. 266-7).

No mesmo volume, o organizador Zizek emite diagnóstico semelhante. "A forma de consciência que se adapta à sociedade 'pós-ideológica' do capitalismo tardio - a atitude cínica e 'sensata' que advoga a 'franqueza' liberal em matéria de 'opiniões' (todo mundo é livre para acreditar no que bem quiser, isso só diz respeito à privacidade), que desconsidera as expressões ideológicas patéticas e segue apenas motivações utilitaristas e/ou hedonistas - continua a ser, stricto sensu, uma atitude ideológica: implica uma série de pressupostos ideológicos (sobre a relação entre os 'valores' e a 'vida real', sobre a liberdade pessoal etc.) necessários à reprodução das relações sociais existentes." (p. 20 do livro acima citado).

É a atmosfera típica dos EUA, em que "cada um é cada um”, que leva à tal polifonia de personagens que é a própria estrutura de Robinson, dando sua receita progressista de multiplicidade e tolerância. O fim da primazia unificadora da economia daria lugar ao retorno do político ao comando da humanidade, mas uma volta liberal e fragmentada. O argumento por trás é que as várias vozes podem deixar o antagonismo interno de lado e acentuar o convívio entre elas e, assim, servir de oposição ao mundo hegemônico da atualidade - o problema é que esse mesmo conservadorismo dominante se traveste de open minded, aceitando toda a manifestação como válida dentro de "nossa sociedade democrática ocidental”, apenas para reafirmar sua posição central.

De tão tolerante, Robinson deu espaço até às corporações capitalistas em seu mundo ideal pós-capitalista. A corporação Práxis se associa aos marcianos e sua presença na nova sociedade só é questionada em algumas reticências iniciais dos líderes do planeta vizinho. Astuta, a solução de Robinson revela a lógica do momento de sua escritura, com empresas e ideologias de fundindo na mesma proporção e experimentando distintas graduações entre os valores idealizados de liberdade e igualdade. 
A democracia liberal é o reino das opiniões, porém, toda e qualquer verdade dita como definitiva é denunciada como totalitária. E como solução para este mundo sem certezas universais, achou-se a solução de chegar perto delas criando uma multidão de perspectivas e narrativas. Assim constrói seu discurso Robinson em sua federação utópica, assim imagina que da multiplicidade surja a liberdade, palavra geralmente usada onde ela não existe. 


\subsection{Marte como espelho dos EUA}

O próprio conceito de federalismo pode ter sido escolhido por Robinson e Jameson para facilitar para o público dos EUA, leitor inicial de seus escritos. Dessa forma, resumiam a imagem dessa sociedade descentralizada e de utopias ao mesmo tempo autônomas e interligadas que formam Marte do século 22.

O ficcionista bem que tenta despistar o leitorado. Dois de seus principais personagens se mostram reticentes diante de comparações entre a independência de Marte e a dos EUA. Frank Chalmers esbraveja com um dos prisioneiros após o levante de Nova Houston, no final de Red Mars (1993, p. 465): "Você e seus amigos tentam viver uma rebelião de fantasia, uma espécie de 1776 de ficção científica, habitantes da fronteira que se livram do jugo dos tiranos. Mas as coisas não são assim. Todas as analogias são errôneas, enganosamente errôneas porque mascaram a realidade.”

O interlocutor não se intimida e responde: “Teremos nossos Washingtons, Jeffersons e Paines, te asseguro (...) em qualquer caso é mais uma metáfora que uma analogia.” Em atitude típica de Frank, sua personagem sai irritada e contrariada: “É ridículo.”

Já John Boone passa por situação similar em conversa com Marian, sua guia na localidade de Senzeni Na, antes da revolução de 2061 estalar (1993, p.348). "Coloquem na cabeça que essa trama de revolução não passa de uma fantasia sobre a Revolução Norte-Americana, já sabem, a grande fronteira, os bravos pioneiros explorados pelo poder imperial, a revolta para passar de colônia a estado soberano... tudo falsa analogia”, diz o primeiro homem a pisar em Marte. Mas, ouvindo os argumentos da interlocutora, ele muda de posição no parágrafo à frente: “Ainda assim, nos separam 80 milhões de quilômetros, e nós estamos aqui e eles não. Talvez não sejam os EUA da época, mas desfrutamos de algumas das mesmas vantagens: estamos muito longe e somos donos do planeta.”

Até o russo Alex Zhalin entra nesse jogo de negação antes de morrer na revolução. "Isto não é a revolução americana, nem a francesa, nem a russa, nem a inglesa. É todas elas ao mesmo tempo e todas as partes”, afirma durante discussão. Há referências a todas essas guinadas da História na trilogia, mas o molde principal em que Robinson formata seu enredo são os eventos que o público norte-americano reconhece como seu passado, aparecendo no planeta vermelho de forma cifrada.

Toda a perspectiva do quadro criado para essa odisséia marciana converge para os Estados Unidos, seguindo a tradição local de vestir seus cowboys com trajes espaciais e comparar a paisagem estéril dos planetas com a do Velho Oeste. Por isso, o país ser seu ponto de fuga único da narração de Robinson, contrastando com o ponto de vista multifacetado e esquivo que nos proporciona o narrador.

Ou seja, a construção da narrativa se refugia em uma estrutura fragmentada e globalizada que estaria na esfera da fancy, enquanto a imagination por trás do relato segue a visão de mundo uniformizadora muito norte-americana. Retirando a camada cosmética de cosmopolitismo, que cita iguarias gregas (a aguardente retsina ou o prato souvlakia), o samovar russo, termos japoneses e costumes árabes, o que há é um pano de fundo claramente estadunidense no livro - sem que haja nenhum traço patriótico.

Por isso, os nomes podem ser de personagens da história russa ou os restaurantes com café expresso fechando as refeições. E o misticismo tem uma clara feição asiática, dando a deixa que há ali um resquício desse orientalismo californiano. 
Tudo é assimilado pela globalização a la norte-americana, com a ideologia do melting pot ao fundo. Todos os sabores e delícias da Terra são empacotados em embalagens descartáveis de delivery fast-food. Todo o mundo cabe no Epcot Center. Se o detalhe é internacional, mas regido pelo prisma dos EUA, as questões de fundo são ainda mais envasadas na origem made in USA.

Em entrevista posterior à publicação, Robinson admitiu similaridades, mas afirmou que não queria nada explícito. E esse trabalho de ocultamento que ele realizou acabou resultando que os EUA estão em toda parte, sem estarem em nenhuma. O país desaparece oficialmente ao final do primeiro volume com a morte de Frank Chalmers, seu representante legal na superfície marciana. Uma cena que escancara essa personificação acontece quando Frank, vestido de smoking (o traje símbolo dos EUA), assina um novo tratado com a UNOMA, liberando a imigração e a exploração mineral, e brinda o documento com a saudação "Pelos Estados Unidos da América”, pensando que essa fala ficaria bem no vídeo para os telespectadores terráqueos.

Mas com o soterramento de Frank na trama, e consequentemente dos Estados Unidos, quem fica com o papel imperial sobre Marte são a versão fictícia do máximo organismo internacional (ONU cria a UNOMA para defender os interesses terráqueos) e das empresas de caráter multinacional.

Por um lado, Robinson encontra um papel ativo para a ONU, que, hoje em dia, atua à reboque das iniciativas dos EUA e sua indústria armamentista, o centro das decisões que ganhando ou não a chancela das Nações Unidas segue como xerife planetário.

Há na trilogia, porém, uma perspectiva que os EUA saiam de seu papel atual de superpotência hegemônica e o mundo fique multipolar. Essas previsões rondam o imaginário local há tempos. No final dos anos 70, o temor era que URSS e Japão tomassem a frente, mas a combalida indústria norte-americana se reergueu com a revolução digital. Em meados da década passada, antes da crise na Ásia de 1996 mostrar as debilidades dos chamados tigres, a tese era que o centro econômico migraria definitivamente para o oceano Pacífico. Com a turbulência global de 2008 centrada em Washington, essa idéia ganha de novo força: um relatório das agências de inteligência dos EUA divulgado em novembro de 2008 aponta que o país perderá força internacional diante da China, Índia e outros países até 2025.

Os EUA robinsonianos do ano 2026 aparecem decadentes e precisando do sucesso da empreitada marciana para recuperar sua posição - situação similar a de sua parceira Rússia, descrita como "uma espécie de gigantesca Coréia que praticava um idêntico e modernizado capitalismo brutal, perfeitamente taylorizado e com um verniz de democracia e bens de consumo que disfarçava as atividades do governo.” (1993, p.453)

Por outro lado, está a idéia que as empresas vão superar em importância os países, visão surgida da comparação do PIB de algumas nações com o patrimônio de certas corporações (os três maiores bilionários, entre eles Bill Gates, têm mais patrimônio que o PIB somado dos 48 países mais pobres do globo).

As empresas agigantadas de Robinson -uma delas se chama Amex - agem na trilogia à semelhança da postura de polícia do mundo que os EUA adotaram nas últimas décadas, com intervenções militares no Oriente Médio e América Latina. 
Contudo, o próprio Jameson vê como falso esse temor. "O lado paranóico desse medo [das empresas engolirem os países] pode ser apaziguado pela cumplicidade que existe entre os Estados e as operações dessas corporações, dada a porta giratória que une os dois, em especial em termos do pessoal que serve ao governo americano", escreve o teórico no ensaio "Globalização e Estratégia Política”, presente no livro A Cultura do Dinheiro (2001, p. 22-3). A relação, portanto, é de complementaridade, com um defendendo o interesse do outro, e os Estados agindo como um tipo de “empresa-mãe”, uma incubadora de empreendimentos privados.

Os EUA estão em tantos lugares no livro que surgem até no contingente russo, que não cumpre o papel de "outro" na trama. Aliás, os estrangeiros em Marte são exatamente os interlocutores da pauta de relações exteriores dos EUA, ou seja, os europeus (em especial, a Rússia, a França, a Inglaterra e a Suíça) e os asiáticos (Japão e Meio-Oriente em destaque). É sintomático que um autor que vive a 700 quilômetros da América Latina não coloque um personagem desta região em seu enredo - o mesmo acontece com a África e Oceania.

Maya, por exemplo, usa imagem de donuts para descrever a nave Ares. Outra comparação bem ianque é feita pelo marciano Peter, dizendo que, visto de sua órbita, Marte se assemelha a uma bola de basquete suja.

Mas, a mais norte-americana das eslavas é a pragmática Nadia. Seu conhecimento em jazz se compara com sua expertise em construções em ambientes gelados, a razão primeira de sua ida para o planeta vizinho. Ela conversa com outro russo, Arkadi, sobre a fase esplendorosa de Louis Armstrong em 1947 e trabalha assobiando melodias da King Oliver's Creole Jazz Band. Nadia também defende os EUA como exemplo a ser seguido como sociedade de tolerância interna. "Os Estados Unidos sempre foram advogados do cadinho de culturas, pela idéia do melting pot. Era um país para o qual as pessoas podiam ir desde qualquer lugar e do qual podia formar parte. Na teoria, pelo menos. Podemos aprender muito desse modelo”, fala para Art (1994, p.422).

O mais revelador, porém, é que Nadia é quem primeiro cita figuras do folclore norteamericano, como Johnny Appleseed, Paul Bunyan e o Grande Homem, que depois ganham trechos inteiros na narrativa para ilustrar um passado mitológico para a paisagem marciana. É nesse instante que o paralelo entre Marte e os EUA fica mais explícito.

O lenhador Paul Bunyan e seu bezerro azul Babe, presentes nas fábulas infantis acima do Rio Grande, simbolizam a vastidão e o gigantismo norte-americanos, e isso é transplantado para o planeta vermelho. O fascínio que o homem normal e corrente tem pelos frutos de seu trabalho é projetado em uma figura mítica na criação do mundo (a história da obra de Deus em sete dias é a mais conhecida no Ocidente). Dessa forma, imagina que um homem gigantesco moldou um planeta que, na verdade, é resultado da ação dos fenômenos físicos e químicos ao longo do tempo.

É uma projeção do próprio trabalho do homem a terraformar Marte. A idéia do desafio que o ambiente marciano representa e a superação humana são uma constante na trilogia. "O trabalho que faz a história avançar, sim, já há muito a fez avançar, conduz para a causa que tem possibilidade de ser boa, não como abismo, mas como montanha para o futuro. Os homens, assim como o mundo, carregam dentro de si a quantidade suficiente de futuro bom; nenhum plano é propriamente bom se não contiver essa fé basilar”, afirma Ernst Bloch para fechar o primeiro volume de O Princípio Esperança (2005). A metáfora geográfica entre o abismo e a montanha mostra a ação do homem, a opção pela transformação (becoming) no lugar de reverenciar o ser (being), tão própria dos utópicos. "Somente ao se abandonar o conceito fechado e imóvel do ser surge a real dimensão da 
esperança. "O mundo está, antes, repleto de disposição para algo, tendência para algo, e o algo assim intencionado significa plenificação do que é intencionado", sentencia Bloch no início do mesmo livro (2005, p.28).

O próprio Robinson declara que quis unir história e geografia nessa escolha pela transformação. "Eu pensei que tinha de alguma forma que incorporar um elemento histórico e um elemento paisagístico - essas coisas globais. Sendo assim o caso, a história da terraformação de Marte, que é um lugar gigantesco para fazer essas coisas utópicas, simplesmente tinha que ser uma história longa. Se eu tenho uma idéia e ela precisa de um longo romance para ser cumprida com sucesso, então, eu fico muito feliz de levar a cabo esse longo romance que lhe faz justiça”, disse em entrevista a The Zone (LAWIE, 2002).

Por isso tantas referências essenciais aos EUA. Há o debate entre o isolacionismo ou o “destino manifesto" de Marte, que faz o centro das decisões migrarem para lá, como os Estados Unidos fizeram o comando mundial atravessar o Oceano Atlântico e deixar a Europa. Fala-se até em uma "febre do ouro" no começo do século 22 depois da recuperação do elevador planetário. O grupo dos "First Hundred" se parece com o Country Founders dos EUA. Por tudo isso, Jameson aponta que a trilogia é "essencialmente anticolonialista, no espírito da Revolução Norte-Americana” (2005, p.195).

Principalmente os eventos relatados do final de Green Mars e do começo de Blue Mars guardam muitos paralelos com a história norte-americana. Marte parece uma nova América, um novo centro, que se distancia e supera sua pátria-mãe, a Terra ou a Inglaterra. A federação marciana recupera diversas idéias pregadas pelo principal ideólogo da Revolução de 1776, Thomas Jefferson, como o autogoverno, liberdade política e democracia participativa (os EUA jeffersonianos inspiraram livros utópicos que pintavam de cor-de-rosa esse momento histórico, assim como aconteceu com a Atenas de Péricles ou o estado Inca no Peru).

Como Bellamy em Looking Backward, Robinson censura a faceta ianque do capitalismo, com uma mistura de radicalismo político, comercialismo deslavado, parafernália tecnológica e propaganda gananciosa, com milhares de técnicas para induzir o consumidor-eleitor-cidadão. Isso para clamar pela igualdade, a irmandade e a abundância prometida no sonho racionalista jeffersoniano.

Dessa forma, a utopia de Robinson teria um lado também de volta mítica a um período de "anos dourados", uma imagem algo similar aos paraísos religiosos e da idéia de retorno a uma época edênica. Esse traço de redenção que está presente na independência dos EUA já vinha da colonização de suas terras, dois séculos antes, como Roberto Schwarz aponta no ensaio "A Letra Escarlate e o Puritanismo”, presente no livro A Sereia e o Desconfiado (1981)

No texto que analisa o clássico de Nathaniel Hawthorne (1804-64), o crítico brasileiro faz um paralelo entre o romance A Letra Escarlate e um livro que relata a história da chegada dos puritanos à América do Norte contada por um deles. É William Bradford (1590-1657) e sua publicação The History of Plymouth Plantation.

Schwarz (1981) resume um enredo algo parecido com a chegada a Marte da tripulação criada por Robinson. “Como outros grupos utopistas e religiosos, os puritanos reconheciam no egoísmo o correlato subjetivo da propriedade privada. Em consequência, aproveitaram o começo da vida nova, na América, para experimentar o comunismo platônico. Ao que parece, os membros da comunidade 
acederam na partilha de seus bens presentes; a dificuldade sobreveio quando não se dispuseram a dividir também a escassez em partes iguais. A repartição desigual da escassez é o correlato negativo da propriedade privada, a sua forma arraigada na cabeça de quem se concebe como produtor de bens particulares. Superá-la não exigia apenas a partição do que já existia - facilitada pela pouca monta da riqueza e pelos perigos da colonização incipiente - como também a partição de todos os esforços individuais futuros, que deveriam buscar a superação comunitária, e não pessoal, da escassez. Provação excessiva, mesmo para puritanos”, escreve Schwarz sobre o relato de Bradford, mostrando que a privação é um limite que a gift economy tem que lidar.

Depois Bradford conta que os pioneiros repartiram a terra em propriedades privadas, a produção aumentou e a colônia na Nova Inglaterra prosperou. "A relação entre egoísmo e propriedade está evidente: as energias que se ausentam quando está em jogo a comunidade, e dizem presente quando o trigo é particular, só podem ser egoístas”, sentencia Schwarz, para comentar a opinião do historiador sobre o "efeito estimulador que o egoísmo tem”. Essa crença ganhou viés biológico recentemente com a tese do gene egoísta, teoria que dava aval científico à defesa do interesse próprio e é citada duas vezes na trilogia de Robinson. A personagem Frank Chalmers usa essa teoria para explicar seu comportamento autocentrado. Em uma passagem mais sarcástica, o gene egoísta reaparece: Phyllis abaixa as calças de Sax, libertando sua ereção, e ele lembra essa teoria.

Em um trecho pinçado pelo ensaísta brasileiro, Bradford continua sua descrição e apresenta a solução encontrada justificando a "racionalidade" da medida, contra-argumentando o ideal platônico de sociedade, que prometeria homens florescentes e felizes: "Pois esta comunidade (tanto quanto o foi) provou criar muito descontentamento e confusão, retardando muita ocupação que teria sido para seu benefício e conforto (...) Ninguém objete que esta corrupção é dos homens, e nada tem a ver com o próprio caminho. Respondo, vendo que todos os homens têm neles esta corrupção, que Deus em sua sabedoria escolheu outro caminho mais próprio para eles”.

Nesse momento, Schwarz aponta o subterfúgio na linha de raciocínio de Bradford: “O apelo a Deus é a muleta do passo falso: o que foi razoável é declarado racional (...) O existente é verdadeiro, impermeável à crítica." Ou seja, o irracional do capitalismo é recoberto com a embalagem de racionalidade, mas se revela nas entrelinhas como na análise que o ensaísta brasileiro faz de A Letra Escarlate, ao ver o porquê da perseguição à protagonista do romance. A adúltera Hester Prynne se vivesse nos EUA da atualidade teria toda uma linha de produtos para acompanhar a letra "A" vermelha costurada em sua roupa, mostrando que o mercado perdoa o pecadilho desde que possa virar um nicho - é só ver as lojas que vendem uma moda que fantasia as pessoas de prostitutas ou gangsters. No lugar de ser consumida pelo fogo em praça pública, Hester poderia agora consumir "nas melhores casas da praça” e desfilar seu orgulho em um episódio do seriado Sex and the City. Ou seja, a irracionalidade que Schwarz viu na sociedade norte-americana ganhou uma nova camada a esconder o pecado original.

Essa mesma lógica se apresenta na obra de Robinson. O comunismo platônico que se frustra também está na trilogia marciana de Robinson, justamente no momento da colonização inicial. Em Underhill, todos se dividem em razão do inóspito do local e do muito que há por fazer no planeta. Entretanto, quando os pioneiros espaciais já estão bem acomodados, começa um fenômeno similar ao descrito na migração puritana. A personagem de John Boone simboliza essa utopia inicial cheia de boas intenções, enquanto o outro norte-americano Frank Chalmers é outra encarnação desse razoável que vira racional, afinal, ele é o representante do governo norte-americano em solo marciano. 
Acaba por vencer a lógica das corporações, que dominam os primeiros anos com seu poderio financeiro, tecnológico e militar, afinal, elas podem dinamizar a terraformação e a criação da economia local. Ao fim e ao cabo, as várias iniciativas privadas servem também para aquecer o planeta vermelho e dar-lhe uma atmosfera semelhante à da Terra - até mesmo as guerras servem para tal propósito.

Essa lógica segue quando o planeta é dividido em cidades-estados que podem estabelecer a lei que quiserem, sem um centralismo que dite todas as normas, em uma mistura de federalismo e liberalismo que é muito cara aos EUA. Confirma-se a piada de que os norte-americanos não conseguem imaginar que existe e como são os outros países e tentam transformar todos em filiais do "Império".

Claro que o limite da imaginação não é exclusividade dos Estados Unidos. Falando das utopias britânicas dos séculos 18 e 19, Terry Eagleton ironiza que os ingleses não conseguem projetar um futuro sem jardins dividindo as casas, afinal, eles desenham seu paraíso em canteiros perfeitos para o verão. Já Robinson mantém as corporações e seus prédios de escritórios com um restaurante na cobertura, bem ao gosto yuppie triunfante do final do século 20. "O que parece mais 'utópico', no sentido de extravagantemente irreal, sobre elas é precisamente sua incapacidade de imaginar um mundo significativamente diferente daquele que os cercam”, satiriza o crítico britânico (2003b, p. 24-5). Ou seja, os pioneiros puritanos na América do Norte repetem uma variável de sociedade européia de então, assim como os marcianos de Robinson são versões siderais dos liberais californianos da década de 90, com sua mistura de movimentos como o progressista liberal, o verde, o feminista, o GLTB, o estudantil, o comunal, o pelos direitos humanos, o pela permaculture (agricultura perene), o pelo associativismo, o pelo cooperativismo, acrescentando aí as adaptações de valores religiosos asiáticos como budismo, taoísmo ou hinduísmo, tão disseminadas e aclimatadas nesse Estado dos EUA.

As cidades imaginadas pelo ficcionista parecem também saídas do mapa da Califórnia, com seus guetos negros, distritos asiáticos, quarteirões chicanos, bairros italianos, condomínios burgueses, lugarejos hippies ou suas "home villages”, como a que Robinson mora em Davis, um local com forte estrutura cooperativa (mesmo assim, dentro da lógica capitalista dos Estados Unidos), criado na década de 70 e que se privilegia a ecologia (a água das chuvas é aproveitada por um sistema de drenagem e as casas têm energia solar).

O escritor conta que incorporou sua vivência por lá em aspectos como a "nanopolítica utópica e na dinâmica de pequenos grupos". Robinson acrescenta a essa fórmula um pouco de experimentação, mas não chega ao extremo de receitar uma revolução para mudar de vez o cenário, afinal, ele também faz parte dessa esquerda intelectual que tem o desejo conflitante de querer a revolução, mas sem a violência descontrolada que elas geram - ou seja, entre o conforto e o confronto, escolhe o primeiro. O próprio ficcionista comete um ato falho em entrevista quando fala em violent revolution no lugar de velvet revolution como desfecho da trama em entrevista televisiva (POTTS, 2000).

Ou seja, Robinson vai ao cerne da questão (a economia), mas volta com uma solução local, como se aquele primeiro assentamento puritano comunista platônico pudesse ser multiplicado e presenteado com as comodidades e amenidades modernas (os norte-americanos adoram para isso a palavra indulgence, para esse consumo compensatório que se apresenta como fim e gratificação na sociedade criada por eles). Quem sabe o Epcot Center possa reproduzir esse paraíso perdido made in USA. 
No nível da imagination, Robinson não consegue divisar um mundo sem grandes empresas, mesmo com selo de qualidade social, ecológica ou administrativa. A forma dessas utopias reflete de volta para nós o mundo real de uma forma suavemente reformada, e dessa maneira ajuda a reforçálo.

No fundo e sem prever essa consequência, essas utopias acabam contando a história do fim da História, equivalentes ficcionais das teses de Francis Fukuyama - figura mais conhecida do endism, ideologia que preconiza que a humanidade chegou ao apogeu com o triunfo da democracia ocidental e do capitalismo, idéia que teve como precursor Daniel Bell que publicou em 1960 O Fim da Ideologia. E que a escola utopista dos EUA é em parte reação a essa lógica, usando o termo utopia como um codinome para "a dinâmica positiva da História”.

Como os EUA organizam o planeta na atualidade, vão querer sistematizar a via láctea à sua maneira (a questão dos imigrantes é outra analogia forte entre Marte e os EUA, repetindo a importância e o temor em torno do tema, que chega até o final da trama).

Porém, na maioria das vezes, o limite de consciência coletiva dos EUA são, em projeção claustrofóbica, seus condados, suas cidades ou seus condomínios particulares. Parece que a utopia igualitária norte-americana é aquela cidadezinha de sonho norte-americano saída dos idílicos anos 50 sob o governo de Dwight Eisenhower (1953-1961), a mesma cidade de fachada do livro Time Out of Joint, de Philip K. Dick. O sonho norte-americano que pode ser ameaçado pelo "perigo vermelho”, pelo “terrorismo árabe” ou, mais recentemente, por uma catástrofe ecológica.

Outro temor, principalmente pelos setores populares e progressistas, é o poder destrutivo das corporações em pequenas localidades. Isso foi registrado recentemente por uma série de documentários norte-americanos, tendo como figura mais visível Michael Moore, que surgiu no cenário artístico e político dos EUA com o filme Roger and Me (1989), que relata o impacto da decisão de Roger Smith, presidente da General Motors, de fechar onze fábricas em Flint (Michigan). Mas há também o exemplo da produção Wal-Mart: The High Cost of the Low Price (2005), mostrando a mobilização das populações de pequenas cidades para barrar a entrada da gigante do varejo norte-americano, com histórico de destruição dos negócios tradicionais e do centro comercial das cidades onde a rede se instala - o curioso é que a oposição se dá muitas vezes liderada por pastores protestantes, que em geral catalizam as ações sociais nos Estados Unidos. As cidades-tendas de Red Mars, frágeis diante do ataque das corporações, se assemelham a esses municípios indefesos diante das decisões dos executivos das multinacionais.

Em sua defesa da autonomia de cada cidade de Marte, a trilogia de Robinson tem também esse viés de defesa das localidades diante do poder central. Poderia ser a história de um município resistindo diante da pressão de gigantes como a GM ou o Wal-Mart de controlar a economia, a política e o meio-ambiente de sua comarca. Nesse aspecto, há um provincialismo norte-americano por trás desse Marte de tantos personagens internacionais e interplanetários (aí está uma discordância com a afirmação de Jameson de que a trilogia é um dos "poucos romances que puderam projetar um panorama pós-colonial de tamanha estatura e dimensão, em um espírito tão distante do provincialismo dos EUA e do universalismo das mercadorias”).

A trilogia é a história de uma revolução que se frustra uma vez, se realiza quase por completo uma segunda vez e só se encerra com um movimento popular de massas que expulsa o último foco das metanacionais e dos interesses terráqueos. 
A desvalorização da revolução sangrenta é típica de nossa época, ainda mais para um produto a ser apresentado no mercado norte-americano, como o livro de Robinson. O conceito de Lenin da violência criadora é algo que não tem lugar no enredo de Robinson e está fadado ao fracasso como aconteceu em 2061 e depois com o movimento Kakaze. Até o nome "revolução" é trocado por "mutação de valores” (werteswandel, em alemão).

No espírito de sua época, o autor defende a revolução de veludo, uma demonstração de força nas ruas que faz os poderosos recuarem, uma manifestação bem ao gosto da esquerda norteamericana defensora das passeatas, da micropolítica e das conquistas paulatinas. Essa é a mesma mitologia que cercou a greve geral na virada do século 19 para o 20, a resistência pacífica de Mahatma Gandhi, as manifestações estudantis nos anos 60 ou as ruas cheias de gente em Teerã durante a Revolução Islâmica.

O mito está em torno dessa revolução aromática, deste tapa com luva de pelica que derruba os governos e dessas passeatas de slogans vaporosos (como a passiva e generalista faixa "Give us something nicer than Capitalism" em protesto contra uma reunião ao G-8 na Alemanha). Nada de fervor revolucionário, nada de barricadas, sangue e mortes. O melhor é promover um fórum, chegar a um documento de reivindicações e clamar por um congresso. Afinal, a impressão reinante é que o mundo é muito complexo (ou fragmentário) para se definir em antagonismo simples, como diriam os pós-marxistas.

Na trilogia marciana, quem age acaba punido. E, como as revoluções fracassam, então, é melhor ser prático e achar outra solução. É como Schwarz (1981) afirma sobre a sensação que fica, após ler Bradford e Hawthorne, de que há uma certeza que "o pecado é da natureza humana; utopias existem para falhar.” A trilogia de Robinson começa narrando a morte do líder utópico John Boone, mostrando uma mórbida semelhança com a abertura de A Letra Escarlate, que de saída expõe que o limite da utopia são o cemitério e a prisão.

O próprio Jameson crava que as melhores utopias "são aquelas que falham da forma mais rotunda" e "servem com o propósito negativo de fazer-nos sabedores de nosso aprisionamento mental e ideológico", afinal, "nossa imaginação é refém de nosso próprio modo de produção" (JAMESON, 2005). E, quando a imaginação tenta escapar desse cativeiro, só consegue se refugiar no modo de consumo, o lugar onde também foi parar a utopia .

O raciocínio é: já que os melhores fins devem restar como idéias destinadas ao fracasso, como um discurso muito bonito, vamos ser práticos e achar outra solução, de forma pragmática. E a trilogia de Robinson relata a lenta doma da geografia marciana e do clamor revolucionário.

Entretanto, três pontos ficam de positivo na narrativa: 1) colocar a discussão sobre a sociedade ideal em primeiro plano; 2) não vir de cara com uma receita pronta; e 3) mostrar a construção passo a passo de uma utopia. Como Suvin afirmou ao falar da esperança de um futuro em aberto, com tempos de ruptura, a ficção científica será "mais importante e em verdade significativa quanto mais claramente evite as soluções definitivas” (p.117 de Metamorphoses of Science Fiction).

A trilogia segue a trilha de uma sociedade melhor e, sem dúvida, chega a um universo mais bem resolvido que o nosso. Contudo, isso se dá recuperando um federalismo que foi deturpado com o passar dos anos. Essa forma de governo também possibilita que não haja um rompimento total com o mundo atual, que poderia formar uma cidade-estado dentro do mostruário delas - possibilita, 
por exemplo, que existam sociedades com características pré-históricas, desde que se obedeçam alguns preceitos como os dos Direitos Humanos - o que é uma incongruência temporal, afinal, a vida humana não existia como valor primordial nesse passado.

A utopia é o fim anunciado, mas só é possível no final do terceiro volume da trilogia de Robinson, quando a sociedade capitalista chega a seu extremo. O happy end pós-moderno só pode se dar após 200 anos de resistência. "Não posso escapar: eu sou um escritor utópico e adoro finais felizes. Eu penso que é justamente para isso que serve a ficção científica”, declarou Robinson em entrevista publicada em outubro de 2005 na New Scientist (ELSE, 2005), famosa revista norteamericana de divulgação científica. Em outra entrevista, para o jornal londrino Guardian (CROWN, 2005), esse "otimista raivoso", como ele mesmo se define, repetiu a idéia. "Eu quero que as coisas acabem bem - uma comédia que se oponha a uma tragédia. Quero um final com casamento e crianças”, declarou, em total concordância com o desfecho de sua trilogia marciana.

A trilogia usa o mesmo expediente daqueles filmes de Hollywood que se estendem e se estendem para dar um final feliz para o público endereçado. Se a saga de Robinson terminasse em Red Mars com a revolução vitoriosa ou massacrada de vez, não seria a solução para uma época que não vislumbra revoluções políticas, fracassadas ou não. $\mathrm{O}$ autor precisou de idas e vindas e uma trama circular para chegar, por meio de muita conversação, a seu fecho multicultural.

A solução, porém, é tão fragmentada como a recomendada pelo capitalismo tardio e o pósmodernismo, que está sintetizado na entonação musical em que Robinson narra a terceira e aveludada revolução, com cortes secos entre coros, fugas, contrapontos, ritmos vagarosos e prestíssimos para o concerto de idéias.

O autor vai procurar e encontrar a solução dentro do próprio sistema que causa o mal que sua utopia quer consertar. O processo lento de construção é elogiado por Jameson, que seguindo a idéia de Suvin, afirma que o importante é mostrar como chegar à utopia, sem apresentar uma receita pronta para ela.

Mas copiou a receita de finais felizes, com casais e suas proles em uma praia paradisíaca. O problema está em chegar a um fecho que obedece à maquininha de narrar, à estagnação múltipla do happy end. Troca-se o "casaram e foram felizes para sempre” e coloca-se no lugar "fizeram a revolução (de veludo) e foram felizes para sempre.” 


\section{REFERÊNCIAS BIBLIOGRÁFICAS}

ADORNO, Theodor W. Prismas, Crítica Cultural e Sociedad. São Paulo: Ática, 2001.

ADORNO, Theodor W; HORKHEIMER, Max. Dialética do esclarecimento. Rio de Janeiro: Zahar, 1985.

BABCOCK, Jay. Kim Stanley Robinson’s Profile. Sci-Fi Universe, 1996. Disponível

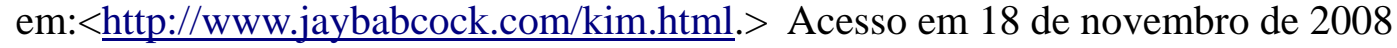

BENJAMIN, Walter. Obras Escolhidas, volume 1, Magia e técnica, arte e política.São Paulo: Brasiliense, 1985.

BLOCH, Ernst. O Princípio Esperança, volume 1. Rio de Janeiro: Contraponto, 2005.

CEVASCO, Maria E. B. P. S. O Sentido da Crítica Cultural. In: Revista Cult, março 2008.

CROWN, Sarah. Future Tense. Guardian, 14 de setembro de 2005. Disponível em:

$<$ http://www.guardian.co.uk/books/2005/sep/14/sciencefictionfantasyhorror.sarahcrown. $>$ Acesso em 21 de novembro de 2008

EAGLETON, Terry. After Theory. London: Allen Lane, 2003.

Figures of Dissent. London: Verso, 2003b.

ELSE, Liz. Global Warming in fiction, an interview with Kim Stanley Robinson. New Scientist , outubro de 2005. Disponível em: <http://www.newscientist.com/article/mg18825206.100-global-warming-infiction.htm>. Acesso em 19 de novembro de 2008

FOOTE, Bud. A Conversation with Kim Stanley Robinson. Science Fiction Studies, março de 1994. Disponível em:<http://www.depauw.edu/sfs/interviews/foote62interview.htm>. Acesso em 18 de novembro de 2008

FRANKO, Carol. The Density of Utopian Destiny in Robinson’s Red Mars”. Revista Extrapolation, vol. 38.[ s.l].: Kent State University Press., 1997.

GEVERS, Nick. Wilderness, Utopia, History. Infinity Plus, setembro de 1999. Disponível em: $<$ http://www.infinityplus.co.uk/nonfiction/intksr.htm> Acesso em 16 de novembro de 2008

JAMESON, Fredric. Archaeologies of the Future. New York: Verso, 2005.

A Cultura do Dinheiro. Petrópolis: Vozes, 2001.

Postmodernism or The Cultural Logic of Late Capitalism. Durham: Duke

University Press, 1991.

Pós-modernismo, a Lógica Cultural do Capitalismo Tardio. São Paulo: Ática, 
1996.

JAMNECK, Lynne. Interview: Kim Stanley Robinson. Strange Horizons, agosto de 1995.

Disponível em: <htttp://www.strangehorizons.com/2005/20050815/robinson-int-a.shtml>. Acesso em 16 de novembro de 2008

KEIM, Brandon. Sci-Fi Author Kim Stanley Robinson Discusses Our Planet's Future. Wired, julho de 2007. Disponível em: <http://www.wired.con/science/planetearth/news/2007/07/stanley_robinson_qa>. Acesso em 15 de novembro de 2008

KURZ, Robert. O Colapso da modernização. São Paulo: Paz e Terra, 1993.

LAWIE, Duncan. This is The Year One. The Zone, março de 2002. Disponível em: < $\underline{\text { http://www.zone- }}$

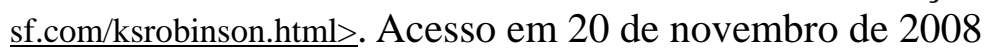

LUKACS, Georg. Teoria do Romance. São Paulo: Editora 34, 2000.

MANUEL, Frank E.; MANUEL, Fritzie P. El Pensamiento Utópico en el Mundo Occidental (volumes 1, 2 e 3). Madrid: Taurus, 1984.

MORE, Thomas. Utopia. São Paulo: Martins Fontes, 1999.

POTTS, Stephen. Guestbook. UCSDTV, julho de 2000. Disponível em:

$<$ http://www.youtube.com/watch?v=Pau5PD40SS-w $>$ Acesso em 21 de novembro de 2008

REVISTA LOCUS (artigo e entrevista não assinados), março de 1996, Oakland, EUA

ROBINSON, Kim S. Red Mars. New York: Bantam, 1993.

Blue Mars. London: Harper Collins, 1996.

Green Mars. London: Harper Collins, 1994.

Los Marcianos. Barcelona: Minotauro, 2003.

RUYER, Raymond. L’Utopie et les utopies. Paris: Presses Universitaires de France, 1961.

SCHWARZ, Roberto. A Sereia e o Desconfiado: Ensaios Críticos. Rio de Janeiro: Paz e Terra, 1981.

SUVIN, Darko. Metamorfosis de la ciencia ficción. Ciudad de México: Fondo Económico de Cultura, 1984.

TOCQUEVILLE, Alexis de; JEFFERSON, Thomas; PAINE, Thomas.. Federalistas. São Paulo: Abril, 1973.

ZIZEK, Slavoj. Bem-vindo ao Deserto do Real!. São Paulo: Boitempo, 2003. 


\section{BIBLIOGRAFIA CONSULTADA}

CLUTE, John; NICHOLS, Peter. The Encyclopedia of Science Fiction. New York: St. Martin's Griffin Edition, 1995.

MORTON, Oliver. Mapping Mars. London: Fourth Estate, 2002.

MUIRHEAD, Brian; REEVES-STEVENS, J. G. Going to Mars. New York: Pocket Books, 2004.

SZEMAN, Imre; WHITEMAN, Maria. Future Politics: An Interview with Kim Stanley Robinson. Science Fiction Studies, fevereiro de 2004. Disponível em:<

http://www.depauw.edu/sfs/interviews/robinson93interview.htm.> Acesso em 16 de novembro de 2008

ZIZEK, Slavoj (org.). Um Mapa da Ideologia. Rio de Janeiro: Contraponto, 1996. 